AUTARQUIA ASSOCIADA À UNIVERSIDADE DE SÃO PAULO

\title{
INFLUÊNCIA DO ENXERTO DE PELE HUMANA IRRADIADA NA REGENERAÇÃO TECIDUAL DE CAMUNDONGOS NUDE
}

\author{
Jurandir Tomaz de Miranda
}

Dissertação apresentada como parte dos requisitos para obtenção do Grau de Mestre em Ciências na Área de Tecnologia Nuclear - Aplicações

Orientadora:

Profa. Dra. Monica Beatriz Mathor 
INSTITUTO DE PESQUISAS ENERGÉTICAS E NUCLEARES

Autarquia associada à Universidade de São Paulo

\section{INFLUÊNCIA DO ENXERTO DE PELE HUMANA IRRADIADA NA REGENERAÇÃO} TECIDUAL DE CAMUNDONGOS NUDE

Jurandir Tomaz de Miranda

Dissertação apresentada como parte dos
requisitos para obtenção do Grau de
Mestre em Ciências na Área
de Tecnologia Nuclear-Aplicações
Orientadora:

Profa. Dra. Monica Beatriz Mathor

Versão Corrigida

Versão Original disponível no IPEN

São Paulo

2016 
A todas as pessoas que me apoiaram Desde o inicio do meu mestrado. 


\section{AGRADECIMENTOS}

Agradeço ao Instituto de Pesquisas Energéticas e Nucleares - IPEN, à Comissão Nacional de Energia Nuclear - CNEN, pelo suporte financeiro da bolsa de estudo e à Agência Internacional de Energia Atômica - AIEA, pelo apoio ao projeto.

A Dra. Monica Beatriz Mathor, pela oportunidade, orientação, confiança, compreensão e pelo desenvolvimento do trabalho.

A Dra. Fabiana Bringel, meu muito obrigado por me autorizar dar a continuidade do trabalho ao qual ela iniciou.

A Dra. Maria Helena Bellini, pelo apoio e suporte cientifico que me engrandeceu em muito como mestrando.

A Dra. Karen Foguer e a Dra. Marina Braga pelos ensinamentos, discussões e pelas varias risadas.

A Dra. Walcy Paganelli Rosolia Teodoro e a Dra. Paula Pereira Velosa, pelo suporte total e incondicional que vocês me passaram, não tenho palavras para agradecê-las.

Ao Dr. Daniel Granato, por toda ajuda e conhecimento passado, muitíssimo obrigado.

Ao grande Dr. Jarbas Bauer pelas aulas, ensinamentos e motivação sempre disposto a levar seu conhecimento independente do local e hora, muito obrigado grande professor.

Ao MSc Rafael Dalbosco, sem palavras pela ajuda e pelo ensinamento.

Ao Dr. Antônio Carlos Martinho Junior, Dr. Rodrigo Crespo Mosca, Mestre Dayane Piffer Luco, Mestranda Ana Funari e Marcos Cardoso valeu pelas dicas e pela força.

Aos amigos Vergaças, Adriano, Kondo, João, Peleias, Ale, Dai, Rodrigo, Bruna, Mari, Maiara, Kirita, Cauê, Benega, Peixe, Ro, Michel, Fernanda, Fernandinho, Michael, Gica, Chamorro, Mascari e todos os atletas e amigos da família POLI RUGBY pelas risadas e principalmente pela zueira hahahah.

Ao inigualável, oráculo da magnificência da sabedoria humana, Dr. Nelson Mendes Alves maior paizão que poderia encontrar.

A Dra. Amanda Koike, muitíssimo obrigado por tudo. 
Meu amigo Gabriel Fonseca Alegre que me levou ao IPEN e me apresentou para o grupo da Dra. Monica, muito obrigado Brother pelo incentivo.

Tenho que agradecer imensamente as futuras cientistas, Verônica muito obrigado pelo seu companheirismo e pela humildade com que sempre teve comigo, Isadora, Fill, Isabele e Laís pela amizade e companheirismo principalmente pelo conhecimento passado por vocês, meu muitíssimo obrigado meninas. Cai literalmente por obra do "destino" de paraquedas, e fico muito feliz por isso ter acontecido.

Tenho que em especial agradecer a Lia Marega que sempre me incentivou a fazer meu mestrado, pelos apertos, alegrias e principalmente amizade, muito obrigado pela ajuda que me deu.

Aos meus pais, que sem eles não estaria aqui, por toda a vivência que me fizeram passar para me tornar um homem digno de respeito. 


\title{
INFLUÊNCIA DO ENXERTO DE PELE HUMANA IRRADIADA NA REGENERAÇÃO TECIDUAL DE CAMUNDONGOS NUDE
}

\author{
Jurandir Tomaz de Miranda \\ RESUMO
}

Nas últimas décadas tem aumentado o interesse pelos enxertos de pele humana radioesterilizadas, para aplicação principalmente em queimaduras extensas e profundas. Isto se deve ao fato destes enxertos apresentarem rápida aderência e menor potencial antigênico, em comparação com os demais tratamentos utilizados. A proposta deste estudo foi avaliar a histoarquitetura do enxerto de pele humana irradiada com doses de $25 \mathrm{kGy}, 50 \mathrm{kGy}$ e não irradiada, durante o processo de reparação tecidual, em camundongos Nude submetidos a enxertia de pele na região dorsal. Três grupos de animais receberam enxertos de pele humana irradiada (25 kGy e 50 kGy) e não irradiada e foram eutanasiados no $3^{\circ}, 7^{\circ}$ e $21^{\circ}$ dia após a realização da cirurgia. Após os procedimentos histológicos de rotina, as amostras de tecido foram coradas com hematoxilina e eosina (HE) para a quantificação de queratinócitos, fibroblastos, células de defesa e vasos sanguíneos e a reação de imunofluorescência (IF) foi realizada para a determinação da expressão de colágeno do tipo I humano e do colágeno dos tipos I e III de camundongo. A quantificação, tanto das células quanto dos tipos de colágeno foi realizada por análise de imagem, utilizando o programa Image-Pro PLus 6.0. Os resultados histológicos demostraram que a pele humana irradiação, quando enxertada, influencia o aumento do número de células no local de cicatrização ao longo do tempo, principalmente na dose de $25 \mathrm{kGy}$, além de proporcionar uma melhor dispersão destas células. No $21^{\circ}$ dia, os três grupos de animais com enxertia de pele humana tiveram parte do enxerto incorporado no processo de cicatrização. O grupo não irradiado apresentou maior incorporação do enxerto (43\%), porém menor produção de colágeno do tipo III de camundongo (22\%). Já os grupos com enxertia de pele irradiada apresentaram menor incorporação do enxerto (6 e 15\%), mas com maior produção de colágeno do tipo III de camundongo ( $35 \%$ e $28 \%$, para $25 \mathrm{kGy}$ e $50 \mathrm{kGy}$, respectivamente). Com este estudo pôde-se concluir que o grupo irradiado a $25 \mathrm{kGy}$, apresenta maior proliferação celular e formação de vasos,além de melhor remodelamento da região de cicatrização.

Palavras-Chaves: Radioesterilização, enxertos, camundongos Nude, pele humana, proliferação celular, imunofluorescência, colágeno. 


\title{
SKIN GRAFT INFLUENCE IN HUMAN TISSUE RADIATED IN NUDE MICE REGENERATION
}

\author{
Jurandir Tomaz de Miranda
}

\begin{abstract}
Over the last few years it has increased the interest in the human skin grafts radio sterilized for application mainly in extensive and deep burns. Because these grafts quickly grip and present antigenic lower potential, compared with other treatments used. The purpose of this study was to evaluate the histoarchitecture of human skin grafts irradiated with doses 25 kGy, 50 kGy and non-irradiated during the pepair tissue process in nude mice submitted by skin grafting in the dorsal region. Three groups of animals received irradiated human skin grafts ( $25 \mathrm{kGy}$ and $50 \mathrm{kGy}$ ) and non-irradiated and were euthanized on the 3 rd, 7th and 21th day after the surgery. Indeed, routine histologic procedures, tissue samples were stained with hematoxylin and eosin (HE) for quantification of keratinocytes, fibroblasts, immune cells and blood vessels and immunofluorescence (IF) was performed to determine the expression human collagen type I and collagen type I and III mouse. Therefore, quantification of both the cells and the collagen types was performed by image analysis using Image-Pro Plus 6.0 software. Histologic results demonstrated at a dose of 25 kGy that human skin irradiation when grafted influences the increase in the number of cells in wound site over time and it provides better dispersion of these cells. In addition, on the 21st day, three groups of animals with human skin graft were embedded part of the graft in the healing process. On the other hand, the group not irradiated showed greater incorporation of the graft (43\%), but less production of collagen type III mouse (22\%). Since the groups irradiated skin graft showed lower graft incorporation (6 and 15\%), but with greater production of collagen type III mice (35\% and $28 \%$ to 25 kGy and 50 kGy, respectively). In conclusion, this study presented that the group irradiated to $25 \mathrm{kGy}$ and it has a higher cell proliferation and vessel formation, and better remodeling of the healing area.
\end{abstract}

Keywords: Radio sterilization, grafts, nude mice, human skin cell proliferation, immunofluorescence, collagen. 


\section{SUMARIO}

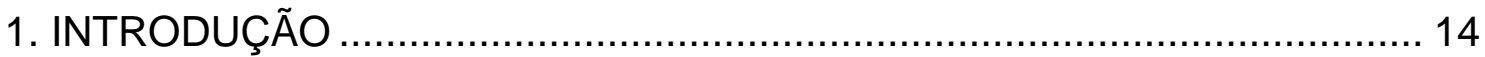

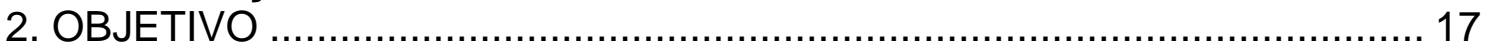

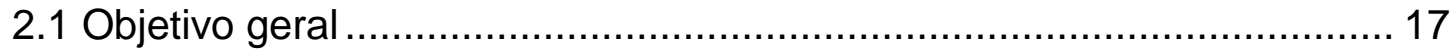

2.1.1 Objetivos específicos .................................................................. 17

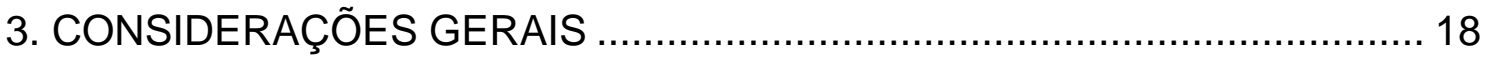

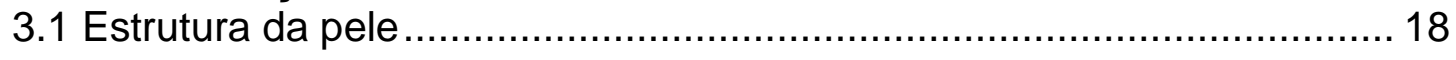

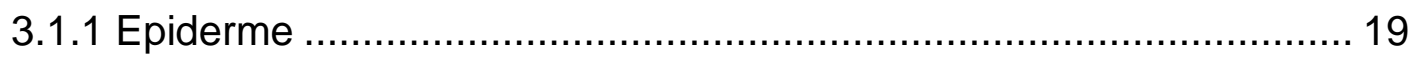

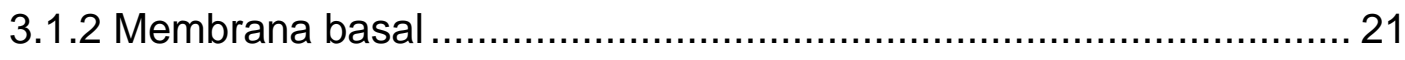

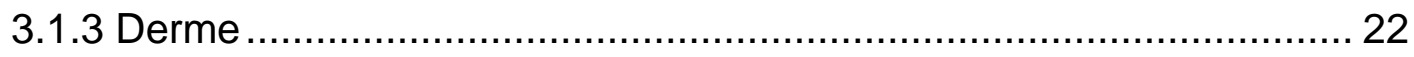

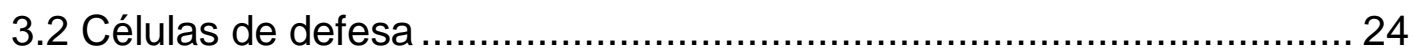

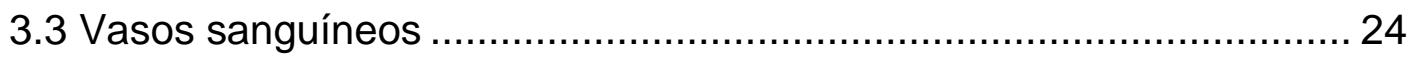

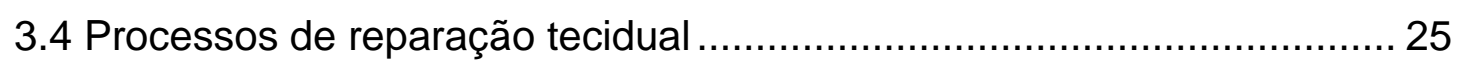

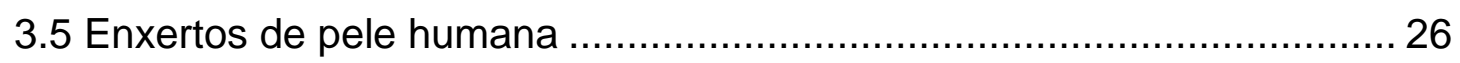

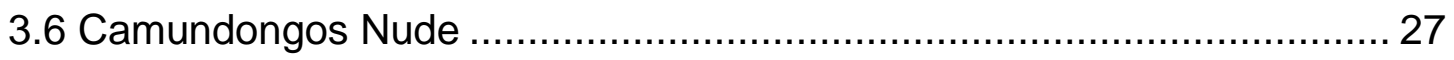

3.7 Comportamento dos enxertos humanos utilizados em camundongos

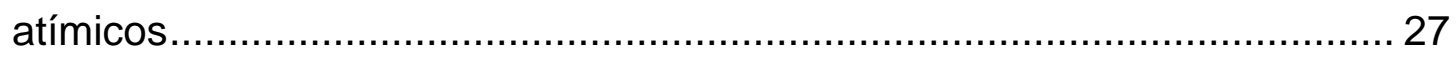

3.8 Radiações e sua absorção pelos materiais ............................................ 28

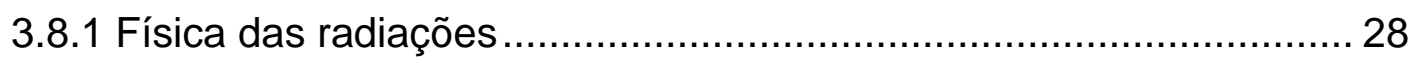

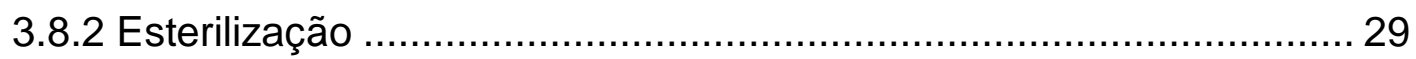

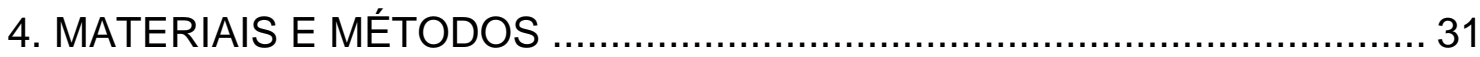

4.1 Divisões dos grupos para análise dos tecidos .................................... 31

4.2 Distribuição celular e de vasos sanguíneos .......................................... 32

4.2.1 Histomorfometria das células e estruturas dos tecidos corados com

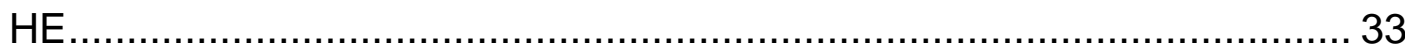

4.2.2 Métodos utilizados nas analises estatísticas dos dados de

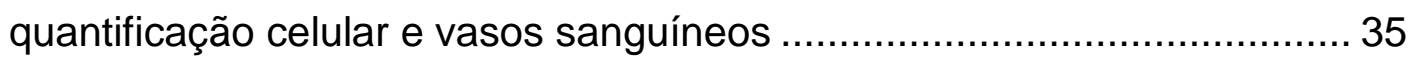

4.3 Cortes dos tecidos para imunofluorescência.......................................... 35

4.3.1 Imunofluorescência para colágeno dos tipos I e III no tecido cutâneo

4.3.2 Histomorfometria do colágeno dos tipos I humano e I III de camundongo no tecido cutâneo de camundongo Nude.

4.3.3 Métodos utilizados para as analises estatísticas dos dados da

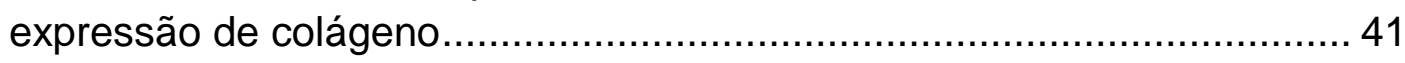

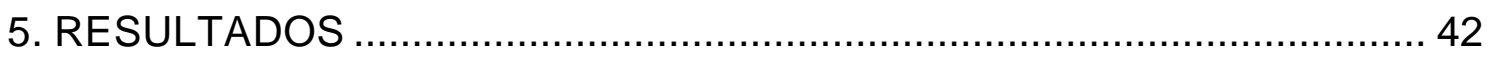

5.1. Distribuição celular e de vasos sanguíneos ao longo da regeneração tecidual. 
5.1.1 Quantificação celular e de vasos sanguíneos ao longo da regeneração tecidual .

5.1.2 Correlação entre as doses de irradiação, tempo e tipos celulares ... 45

5.1.3 Distribuição da média das medianas da quantidade de células, divididas nas datas de eutanásia e localização no tecido.

5.2 Expressão do colágeno tipo I humano e do colágeno dos tipos I e III de camundongo após enxerto de pele irradiada e não irradiada

5.2.1 Quantificação da distribuição do colágeno tipo I humano na área de reparação tecidual

5.2.2 Quantificação da distribuição do colágeno tipo III de camundongo na área de reparação tecidual 51

5.2.3 Quantificação da distribuição do colágeno tipo I de camundongo na área de reparação tecidual .. 53

5.3 Analise da influencia do tecido irradiado na regeneração do tecido animal

6. DISCUSSÃO 55

7. CONCLUSÃO. 62

8. APÊNDICES. 63

9. TRABALHOS FUTUROS 70

10. REFERÊNCIAS BIBLIOGRÁFICAS 71

11. ANEXOS 78 


\section{LISTA DE FIGURAS}

Figura 1 - Desenho esquemático das estruturas da pele.. 18

Figura 2 - Camadas da pele humana, evidenciando a epiderme, suas estruturas e células correspondentes

Figura 3 - Desenho esquemático representando como as moléculas de colágeno (tropocolágeno) se agregam para formar fibrilas, fibras e feixes..

Figura 4 - Fluxograma do procedimento de trabalho das lâminas com tecidos coradas com HE e Imunofluorescência..... 32

Figura 5 - Corte histológico do tecido de camundongo enxertado com pele humana, eutanásiado no $21^{\circ}$ dia após enxertia. 33

Figura 6 - Ilustração representativa da avaliação das células e estruturas na derme de camundongo, por análise de imagem.. 34

Figura 7 - llustração representativa das imagens dos tecidos, vistas ao microscópio, para avaliação das células e vasos sanguíneos.. 34

Figura 8 - llustração representativa da avaliação das fibras de colágeno I humano (verde fluorescente) na derme, por análise de imagem.. 38

Figura 9 - Ilustração representativa da avaliação das fibras de colágeno III de camundongo (verde fluorescente) na derme, por análise de imagem. 39

Figura 10 - Ilustração representativa da avaliação das fibras de colágeno I de camundongo (verde fluorescente) na derme, por análise de imagem. 40

Figura 11 - Fotomicrográfia dos cortes histológicos dos tecidos analisados, corados com HE. 43

Figura 12 - Representação gráfica da distribuição da média das medianas da quantidade de células, divididas nas datas de eutanásia e localização no tecido.

Figura 13 - Detecção de colágeno, por imunofluorescência, (verde fluorescente) em cortes transversais da pele de camundongos Nude, eutanasiados no $21^{\circ}$ dia após enxertia... 48

Figura 14 - Gráficos da quantidade de colágeno tipo I humano no tecido de camundongos Nude, eutanasiados no $21^{\circ}$ dia, segundo sua localização e dose de irradiação. 
Figura 15 - Gráficos da quantidade de colágeno tipo III de camundongo no tecido de camundongos Nude, eutanasiados no $21^{\circ}$ dia, segundo sua localização e dose de irradiação.

Figura 16 - Gráficos da quantidade de colágeno tipo I de camundongo no tecido de camundongos Nude, eutanasiados no $21^{\circ}$ dia, segundo sua localização e dose de irradiação. 53

Figura 17 - Histologia das amostras, coradas com HE, evidenciando o remodelamento 54 


\section{LISTA DE TABELAS}

Tabela 1 - Anticorpos utilizados em imunofluorescência ................................. 37

Tabela 2 - Distribuição e quantidade de queratinócitos, fibroblastos, células de defesa e vasos sanguíneos nos enxertos não irradiados e irradiados a 25 kGy e 50 kGy nos grupos com $3^{\circ}, 7^{\circ}$ e $21^{\circ}$ dias de enxertia ....................... 44

Tabela 3 - Correlação entre dose de irradiação do enxerto com os tempos ( $3^{\circ}$, $7^{\circ}$ e $21^{\circ}$ dias) após enxertia e localização dos queratinócitos, fibroblastos, células de defesa e vasos sanguíneos 45 


\section{LISTA DE APÊNDICES}

Apêndice $A$ - Tecidos dos dos controles corados com HE, pele humana não irradiada, irradiada a 25 e $50 \mathrm{kGy}$ e pele de camundongo Nude 63

Apêndice B - Matriz de correlação linear entre dose de radiação e tempo de análise com os parâmetros de cicatrização. 64

Apêndice $C$ - Distribuição dos valores médios dos grupos de doses por tempo de eutanásia e quantidade celular de cada animal 65

Apêndice D - Controle das amostras das imunofluorescência dos tecidos de pele de camundongo NUDE e pele humana não irradiada e irradiada 25 kGy e 50 kGy, e marcação dos colágenos I humano, colágeno III e I de camundongo. 66

Apêndice $E$ - Distribuição da imunofluorescência dos tecidos do grupo não irradiado do $21^{\circ}$ dia após enxertia, com a IF de colágeno I humano, colágeno I e III de camundongo

Apêndice F - Distribuição da imunofluorescência dos tecidos do grupo de 25 kGy do $21^{\circ}$ dia após enxertia, com a IF de colágeno I humano, colágeno I e III de camundongo 68

Apêndice $\mathrm{G}$ - Distribuição da imunofluorescência dos tecidos do grupo de 50

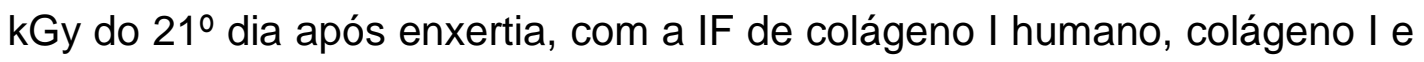
III de camundongo 69 


\section{LISTA DE ANEXO}

Anexo A - Aspecto macroscopico das feridas e areas de reparação dos animais dos grupos experimentais com $3^{\circ}, 7^{\circ}, 21^{\circ}$ e $90^{\circ}$ dias após o enxerto

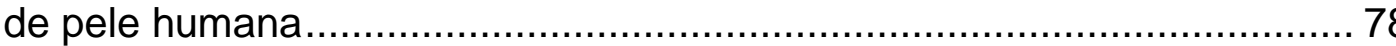




\section{LISTA DE ABREVIATURAS E/OU SIGLAS}

ANOVA = Analise de variância unifatorial

BSA $=$ Soro Albumina Bovina

$\mathrm{CB}=$ Centro de Biotecnologia

CEPA = Comitê de Ética em Pesquisa Animal

CNEN = Comissão Nacional de Energia Nuclear

DER = Derme

DNA = Ácido desoxirribonucleico

$E P=$ Epiderme

FMUSP = Faculdade de Medicina da Universidade de São Paulo

$\mathrm{HE}=$ Hematoxilina e eosina

IAEA = Agencia Internacional de Energia Atômica

ICB = Instituto de Ciências Biomédicas

IF = Imunofluorescência

IPEN = Instituto de Pesquisas Energéticas e Nucleares

IQN = Intervalo interquartílico normalizado

kGy = KiloGray

MANOVA = Analise de variância multifatorial

PBS = Tampão fosfato de sódio

PDGF = Fator de crescimento derivado de plaquetas

RNA = Ácido ribonucleico

TGF $\beta 1$ = Fator de crescimento transformante beta 


\section{INTRODUÇÃO}

A Agência Internacional de Energia Atômica (IAEA) vem promovendo e incentivando o desenvolvido de programas internacionais e nacionais de bancos de tecidos, com o objetivo de utilizar a radiação ionizante como forma de esterilização final em tecidos humanos para transplantes (Dziedzic-Goclawska, 2001).

Segundo Mordiffi \& Nather (2001) existem vários métodos químicos utilizados para a esterilização de tecidos, como o óxido de etileno, peróxido de hidrogênio, ácido peracético e glutaraldeído, porém todos podem deixar resíduos tóxicos no material.

De acordo com Dziedzic-Goclawska et al. (2005) a esterilização por radiação ionizante é um método físico, onde ocorre aumento moderado da temperatura, o que o torna passível de ser usado. A eficácia da utilização da radiação como método de esterilização é decorrente da sua grande capacidade de penetração na matéria e de sua alta eficiência em inativar micro-organismos, além de permitir a esterilização de materiais que estejam em embalagens previamente fechadas, desta forma prevenindo uma recontaminação posterior.

As lesões por queimaduras de grande extensão são um importante problema de saúde publica que resulta em uma alta taxa de morbidade e mortalidade dentre dos pacientes (Tugcu et al., 2015). A pele, que é o maior órgão do corpo humano, correspondente a $16 \%$ do seu peso corporal, desempenha múltiplas funções como proteção, regulação da temperatura, percepção sensorial, excreção e síntese de vitamina $D$, colesterol e melanina (Gartner \& Hiatt, 2007; Junqueira \& Carneiro, 2013).

O enxerto de pele humana é a parte de um tecido transplantado de um lugar para outro em organismos distintos ou no mesmo organismo (Burd et al., 2002). Segundo Golcman \& Golcman (2002) dependendo da sua origem, os enxertos podem ser classificados como autógenos (do próprio indivíduo), alógenos (indivíduos geneticamente diferentes, mas da mesma espécie), 
isógenos (entre indivíduos geneticamente idênticos) e xenógenos (indivíduos geneticamente diferentes e de outra espécie).

Durante os últimos anos, uma grande gama de matrizes não dérmicas vem sendo propostas para substituir os enxertos de pele humana, incluindo os produtos sintéticos, semi-sintéticos ou naturais. Apesar do grande avanço no campo da ciência e bioengenharia de tecidos, os aloenxertos de pele ainda se mantêm como "padrão ouro" na cobertura temporária de queimaduras extensas e profundas (Mackie, 2001). Os aloenxertos possuem inúmeras das propriedades desejáveis da pele autóloga, pois apresentam a capacidade de aderir ao leito da ferida, fornecendo um melhor fechamento, promovendo a retenção da umidade e melhorando a termorregulação do local enxertado (Villapalos et al., 2010; Franchini et al., 2009).

Conforme Obeng et al. (2001) a utilização de aloenxertos de pele cadavérica é mais segura e economicamente viável em comparação com outras coberturas biológicas temporárias. Para minimizar o risco de transferência de doenças, os bancos de pele seguem protocolos submetendo os potenciais doadores multi-órgãos à triagem pelos antecedentes médicos e sociais, além da retirada de sangue para rigorosa análise sorológica (Herson \& Mathor, 2006). Outra preocupação se refere à contaminação do enxerto durante o processo para armazenamento desse tecido.

Apesar da limpeza feita com substâncias antissépticas antes da coleta e após a incubação da pele em recipiente com antibióticos, os controles microbiológicos dos enxertos devem ser realizados na rotina laboratorial, e quando detectada alguma forma de contaminação dos materiais ou do tecido, estes devem ser descartados (Lofêgo-Filho et al., 2006).

$\mathrm{Na}$ literatura existem vários trabalhos demonstrando que a utilização de irradiação de tecidos com baixas doses (abaixo de 25 kGy), é vantajosa por manter melhor a preservação da matriz de colágeno, além de preservar proteínas e fatores de crescimento, levando a uma melhor incorporação do enxerto (Nguyen et al., 2011).

Como visto em vários trabalhos científicos um dos modelos mais utilizados em transplante de tecidos é o camundongo Nude (Wang et al., 2010; RossioPasquier et al., 1999; Foster et al., 1983), desta forma este animal foi escolhido para o estudo por não rejeitar enxertos, tolerando a integração de transplantes de 
doadores não histocompatíveis e até mesmo de transplantes xenogenéticos, estes animais são portadores de deficiência imunológica por linfócitos $T$, não apresentando timo ou possuindo timo rudimentar (Foster et al., 1983).

Conforme os estudos de Bourroul (2004), foi avaliado que doses acima de 25 kGy implicam em alterações na derme, provocando significativas alterações das fibras de colágeno I, essas alterações resultam na diminuição das propriedades biomecânicas do tecido em relação a resistência e tração, modificando a estrutura da matriz extracelular.

No estudo de Bringel (2011), devido à alteração da matriz extracelular causada pela irradiação na pele humana, foi proposto o estudo "in vivo" em camundongos Nude, para analisar o emprego destes enxertos esterilizados por radiação com doses de $25 \mathrm{kGy}$ e $50 \mathrm{kGy}$, comparadas ao grupo controle com tecido não irradiado, para estabelecer se as alterações verificadas "in vitro" poderiam implicar em diferenças no reparo tecidual.

Durante o período de reparo, o processo de remodelamento da cicatriz envolve etapas sucessivas de produção de fibrilas de colágeno. A deposição de colágeno ocorre de maneira aleatória tendo como orientação a organização da fibronectina, dependendo da natureza das tensões aplicadas ao tecido (Balbino et al., 2005).

Neste estudo foi avaliada, no local de reparo, a proliferação celular de queratinócitos, fibroblastos, células de defesa e vasos sanguíneos, para verificar possíveis alterações na proliferação celular. Também foi estabelecida a presença de fibras de colágeno do tipo I humano, assim como a produção de colágeno do tipo I e III de camundongo, com objetivo de evidenciar a presença do enxerto de pele humana e das fibras de colágeno animal no local da cicatrização. 


\section{OBJETIVO}

\subsection{Objetivo geral}

Avaliar a utilização in situ do enxerto humano irradiado, observando se este serviu de arcabouço para a reparação tecidual ou somente como cobertura temporária.

Dessa forma poderá ser avaliado como o enxerto de tecido humano irradiado influenciou na regeneração da pele do animal.

\subsubsection{Objetivos específicos}

- Analisar o crescimento celular e de vasos sanguíneos nos tempos de 3ㅜㅡ, $7^{\circ}$ e $21^{\circ}$ dias.

- Investigar a presença de colágeno tipo I humano no tecido dos animais eutanásiadas no $21^{\circ}$ dia.

- Analisar a presença de colágeno tipo I e III de camundongos Nude no local de cicatrização, eutanásiados no $21^{\circ}$ dia.

- Analisar a influência do tecido irradiado na qualidade da regeneração tecidual. 


\section{CONSIDERAÇÕES GERAIS}

\subsection{Estrutura da pele}

A pele é o maior órgão do corpo humano, sendo integrante do sistema tegumentar, e tem por principais funções a proteção dos tecidos subjacentes, regulação da temperatura corporal, excreção de sais e síntese de vitaminas (Kierszenbaum \& Tres, 2012).

A estrutura da pele é dividida em três camadas que são: epiderme que é a camada mais superficial da pele, sendo não vascularizada; derme papilar e derme reticular, que são denominadas de derme, sendo vascularizada e altamente colagenosa e formada por tecido conjuntivo; a hipoderme que é principalmente constituída por células adiposas, também vascularizada, contendo terminações nervosas, glândulas e ligação com tecido muscular (Kierszenbaum \& Tres, 2012; Junqueira \& Carneiro, 2013). A pele ainda possui anexos como, unhas, pelos, glândulas sudoríparas e sebáceas com varias funções especializadas (Kerr, 2000), como podemos ver na FIG. 1.

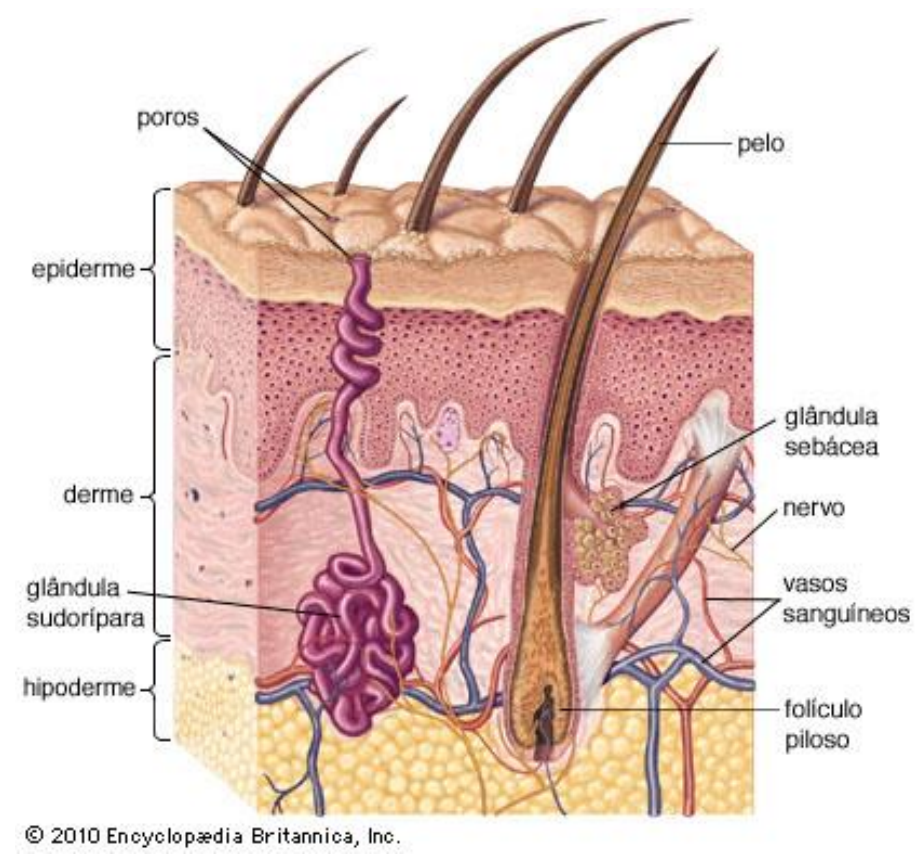

Figura 1 - Desenho esquemático das estruturas da pele. Divididas em epiderme, derme, hipoderme e anexos (folículos piloso, glândulas sebáceas e sudoríparas, vasos sanguíneos e nervos). Disponível em: (http://escola.britannica.com.br/assembly/135568/A-pele-humana-tem-trescamadas-a-epiderme-a-derme). 


\subsubsection{Epiderme}

A epiderme humana (FIG. 2) é constituída por epitélio estratificado pavimentoso queratinizado. Neste tecido são encontrados quatro tipos celulares: queratinócitos (barreira mecânica, produção de citocinas e sinalização celular), melanócitos (síntese de pigmentação, proteção contra ações nocivas dos raios ultravioletas), células de Langerhans (apresentação de antígenos) e células de Merkel (síntese de catecolaminas e sensibilidade tátil) (Kierszenbaum \& Tres, 2012; Rabe et al., 2006).

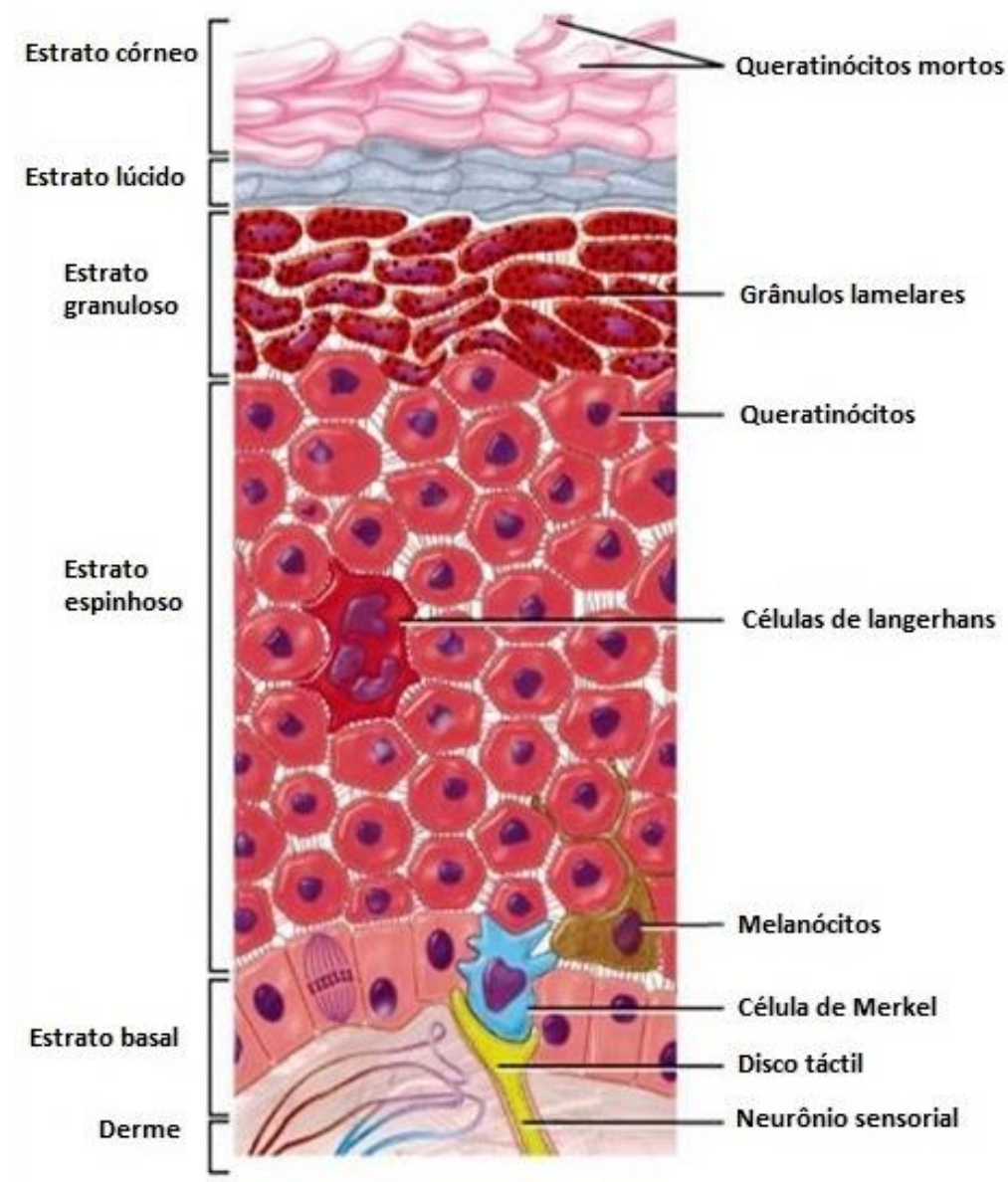

Figura 2 - Camadas da pele humana, evidenciando a epiderme, suas estruturas e células correspondentes. Fonte: adaptado de lookfordiagnosis. Disponível em: (http://www.lookfordiagnosis.com/mesh_info.php?lang=1\&term=Keratinocytes)

\subsubsection{Queratinócitos}

O tipo celular predominante da epiderme é o queratinócito (FIG. 2) estes possuem um padrão bastante variado e mutável quanto à química dos filamentos de queratina, visto que estes se modificam de acordo com a sua maturidade (Kierszenbaum \& Tres, 2012). 
De acordo com este processo de queratinização, a epiderme é usualmente dividida em camadas que representam os diferentes estágios de maturação dos queratinócitos (Standring, 2008).

Segundo Kierszenbaum \& Tres (2012) os queratinócitos são organizados em cinco camadas, sendo elas o estrato basal, estrato espinhoso, estrato granuloso, estrato lucido e estrato córneo. As primeiras camadas celulares consistem em células metabolicamente ativas, as células das duas últimas camadas sofrem queratinização ou cornificação, um processo que envolve mudanças moleculares, celulares e intercelulares. As células do estrato basal sofrem mitose, enquanto algumas das células em divisão são acrescentadas à população de células-tronco do estrato basal, outras migram para o estrato espinhoso a fim de iniciar o processo de diferenciação, finalizando com a formação do estrato córneo.

\subsubsection{Melanócitos}

Os melanócitos são células localizadas no estrato basal da epiderme, derivados dos melanoblastos, células estas precursoras que migram da crista neural embrionária. Os melanócitos se inserem na epiderme em desenvolvimento, são células independentes e se prendem a membrana basal por meio dos hemidesmossomos, sendo que sua renovação é mais lenta comparada com os queratinócitos (Junqueira \& Carneiro, 2013; Kierszenbaum \& Tres, 2012; Ross \& Pawlina, 2012).

De acordo com Kierszenbaum \& Tres (2012) os melanócitos produzem melanina, contida nos melanossomos, que são transferidos aos queratinócitos adjacentes através de seus prolongamentos ramificados chamados de dendritos de melanócitos, e são liberados por secreção citócrina. A melanina é inicialmente armazenada em pré-melanossomos revestidos por membrana e derivados do aparelho de Golgi.

\subsubsection{Células de Langerhans}

Células de Langerhans são células muito ramificadas, derivadas da medula óssea, presentes na epiderme, localizam-se por toda a epiderme entre os queratinócitos, porem são mais frequentes na camada espinhosa, estão envolvidas na resposta imunológica, em particular na apresentação como 
antígenos as células T. (Junqueira \& Carneiro, 2013; Kierszenbaum \& Tres, 2012).

Segundo Banchereau \& Steinman (1998) o processo de maturação das células de Langerhans é iniciado logo após o seu contato com um antígeno, sendo a sua migração em direção aos linfócitos, simultânea com a sua maturação, que é traduzida por típicas alterações funcionais e fenotípicas desta célula.

As células de Langerhans penetram nos vasos linfáticos na derme e migram para os linfócitos regionais, onde interagem com as células $T$ do córtex profundo, as células $\mathrm{T}$ ativadas pelo antígeno epidérmico entram na circulação sanguínea, alcançam o local no qual o antígeno epidérmico esta presente, liberando citocinas pró-inflamatórias com o objetivo de neutralizar o antígeno (Kierszenbaum \& Tres, 2012; Ross \& Pawlina, 2012).

\subsubsection{Células de Merkel}

As células de Merkel são encontradas na região mais profunda da epiderme, junto com a membrana basal, presas aos queratinócitos pelos desmossomos e em contato com fibras nervosas como mielínica aferente com projeção da derme para a epiderme (Junqueira \& Carneiro, 2013; Kierszenbaum \& Tres, 2012). Estas fibras nervosas torna-se amielínica após ultrapassar a lâmina basal da epiderme expandindo-se em terminações sensitivas em forma de placa nervosa que está ligada a células de Merkel (Kierszenbaum \& Tres, 2012).

\subsubsection{Membrana basal}

A membrana basal é a camada que integra a interface dermo-epidérmica, diferenciando-se dos tecidos adjacentes, estrutura e composição molecular. $\mathrm{Na}$ membrana basal encontra-se fixados os queratinócitos através de hemidesmossomos; na região mais profunda, a laminina e a fibronectina, proteínas distintas da matriz extracelular, encontram-se associadas a uma rede de colágeno (Harris, 2009).

A membrana basal é composta por dois componentes: a lâmina basal e a lâmina reticular. A lâmina basal é uma matriz extracelular em formato de lâmina que mantém contato direto com a superfície das células epiteliais, tendo origem 
no arranjo de moléculas de laminina, entactina e proteoglicanas. A lâmina reticular é constituída por fibras de colágeno, que fornecem a sustentação para a lâmina basal, sendo sucessiva ao tecido conjuntivo (Kierszenbaum \& Tres, 2012).

\subsubsection{Derme}

A derme é composta pelo tecido conjuntivo sobre o qual se apoia a epiderme. Do ponto de vista estrutural os componentes do tecido conjuntivo podem ser divididos em: células residentes e migratórias, além de matriz extracelular. Algumas células deste tecido são formadas localmente (residentes) e permanecem no tecido conjuntivo (fibroblastos, macrófagos, mastócitos, plasmócitos, células adiposas e leucócitos), (Junqueira \& Carneiro, 2013).

A derme é constituída por duas camadas, de limites pouco definidos: a papilar que é superficial e a reticular que é mais profunda.

A camada papilar é constituída por numerosas papilas que se interligam às pregas epidérmicas, formando a junção dermoepidérmica. A interface juncional é estabilizada pelos hemidesmossomos que ancoram os queratinócitos à lâmina basal.

Camada reticular é mais espessa, constituída por tecido conjuntivo denso, contendo muitas fibras de colágeno e fibras elásticas grossas (Junqueira \& Carneiro, 2013; Kierszenbaum \& Tres, 2012).

\subsubsection{Fibroblastos}

Os fibroblastos tem sua origem das células mesenquimais indiferenciadas, tem como principal função a manutenção da integridade do tecido conjuntivo pela síntese dos componentes da matriz extracelular. São os principais constituintes celulares do tecido conjuntivo, aparecendo desta forma em praticamente todos os tecidos e órgãos do corpo que possuem este tipo de tecido (Masseno et al., 2010).

Como maior componente celular do tecido conjuntivo, os fibroblastos são células capazes de modular a sua capacidade metabólica, passando por mudanças fenotípicas acentuadas, ou seja, do fenótipo de células imaturas migratórias e replicativas no início do processo de reparação, para o fenótipo característico de células ativamente engajadas na síntese proteica, onde seu citoplasma se torna volumoso e apresenta um retículo endoplasmático rugoso 
abundante. Com isto, passam a secretar grandes quantidades de colágeno (Balbino et al., 2005).

\subsubsection{Colágeno}

O colágeno é a família de proteínas mais abundante do organismo, representando cerca de $30 \%$ do seu peso seco. Eles distinguem entre si pela composição molecular, características morfológicas, distribuição, função e patologias. A família do colágeno é composta por mais de vinte tipos geneticamente diferentes, sendo que os mais frequentes na derme são os tipos I, II, III, IV, V, VI, VII e todos de estrutura fibrilar (Sampaio \& Rivitti, 2007).

O principal componente fibroso da derme humana é o colágeno tipo I, uma proteína insolúvel em forma de fibra que representa 80 a $90 \%$ do colágeno da derme (Sampaio \& Rivitti, 2007). As fibras de colágeno (FIG. 3), formadas por colágeno I, estão presentes na derme reticular e são responsáveis pela resistência do tecido às forças de tensão (Junqueira \& Carneiro, 2013)

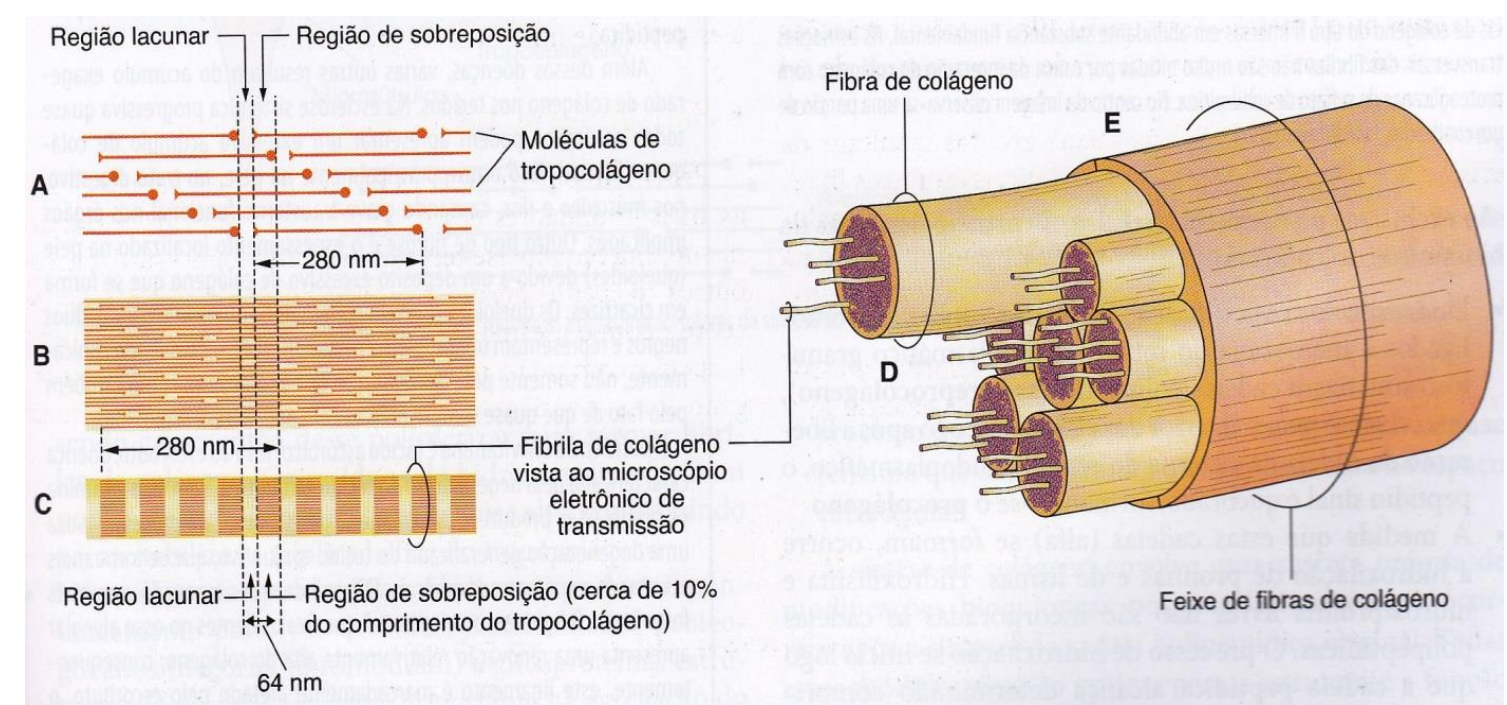

Figura 3 - Desenho esquemático representando como as moléculas de colágeno (tropocolágeno) se agregam para formar fibrilas, fibras e feixes. Cada uma das unidades de tropocolágeno mede $280 \mathrm{~nm}$ de comprimento e se sobrepõem umas às outras (A). Este arranjo resulta em regiões de sobreposição e regiões lacunares (B) que resultam na estriação transversal característica da fibrila de colágeno com faixas claras e escuras que se alternam a cada $64 \mathrm{~nm}$, como observado ao microscópio eletrônico (C). Os agregados de fibrilas formam as fibras (D) que tornam a se agregar para formar os feixes (E) rotineiramente denominados de fibras de colágeno. Fonte: Junqueira \& Carneiro, 2013. 
O colágeno tipo III é formado por fibras reticulares, encontram-se na região papilar da derme (Junqueira \& Carneiro, 2013). Ele é inicialmente produzido no tecido de granulação e está relacionado à plasticidade do tecido nas fases iniciais de reparação (Schurch et al., 2006). Este colágeno corresponde de 8 a 12\% do colágeno dérmico e encontra-se em contato com estruturas como vasos sanguíneos (Junqueira \& Carneiro, 2013; Sampaio \& Rivitti, 2007). O colágeno tipo III não é visível à coloração de $\mathrm{HE}$, devido ao seu diâmetro reduzido e à sua disposição frouxa, essas fibras criam uma rede flexível em órgãos que são sujeitos a mudanças fisiológicas de forma e volume (Junqueira \& Carneiro, 2013).

A degradação do colágeno modifica suas propriedades biomecânicas e consequentemente interfere nas características biomecânicas da pele, uma vez que essa proteína fibrosa, inelástica e flexível da derme é responsável pela integridade e resistência às tensões multidirecionais a que o tecido pode ser submetido (Ottani et al., 2001).

\subsection{Células de defesa}

Os dois elementos-chave do sistema imunológico são os linfócitos e as células acessórias. Os linfócitos incluem dois tipos principais: linfócitos $B$, que respondem a antígenos livres e ligados a células; e linfócitos $\mathrm{T}$, subdivididos em duas categorias: linfócitos $T$ auxiliares e linfócitos $T$ citolíticos ou citotóxicos. Os linfócitos $T$ respondem a antígenos ligados a e células apresentados por moléculas especificas. As células acessórias incluem dois tipos celulares derivados de monócitos: macrófagos e células dendríticas. Um exemplo de células dendríticas são as células de Langerhans, encontrada na epiderme (Kierszenbaum \& Tres, 2012).

Nos camundongos Nude, encontram-se células de defesa do tipo linfócitos B e deficiência de linfócitos T (Andrade et al., 2002).

\subsection{Vasos sanguíneos}

Os vasos sanguíneos são formados por artérias e veias, sendo que as artérias são uma serie de vasos eferentes que se tornam menores à medida que se ramificam, e cuja função é levar o sangue, com nutrientes e oxigênio, para os tecidos, estes possuem vários diâmetros, havendo uma transição gradual das artérias de grande calibre para artérias de médio calibre, bem como para as 
pequenas artérias e arteríolas. As veias resultam da convergência dos vasos capilares em um sistema de canais que se tornam cada vez mais amplos à medida que se aproximam do coração. A maioria das veias é de pequeno e médio diâmetro, cujo valor varia de 1 a $9 \mathrm{~mm}$. Os capilares são vasos muito delgados e constituem uma rede complexa de túbulos finos, seu diâmetro varia de 7 a $9 \mu \mathrm{m}$ e em sua extensão normal não ultrapassa $50 \mu \mathrm{m}$. (Junqueira \& Carneiro, 2013; Kierszenbaum \& Tres, 2012).

\subsection{Processos de reparação tecidual}

Após a injúria, há vasoconstrição como resultado de descargas adrenérgicas por ação das células nervosas, tamponamento da lesão pela adesão e agregação plaquetária formando um trombo rico em plaquetas, que é rapidamente infiltrado pela fibrina, transformando-se em um trombo fibroso. Esse trombo passa a capturar eritrócitos e por isso se torna conhecido por trombo vermelho. O trombo vermelho provoca a completa oclusão dos vasos rompidos e se torna arcabouço para a migração das células responsáveis pelo processo de reparação. As plaquetas são as primeiras a chegar à pele lesionada. Tornam-se ativadas e liberam mediadores químicos que promovem quimiotaxia de células envolvidas na resposta inflamatória. Ocorre uma migração dos neutrófilos e monócitos para a superfície da ferida e ocorre à produção de citocinas e fatores de crescimento, tal como o TGF. Este fator estimula os fibroblastos a produzir colágeno e fibronectina que promove a formação de tecido de granulação (Bolgiani \& Benain, 1993; Balbino et al., 2005).

O colágeno inicialmente produzido no tecido de granulação é do tipo III e está relacionado nas fases iniciais de reparação. O tecido de granulação é reabsorvido, após o fechamento da ferida, os miofibroblastos desaparecem por apoptose e é possível identificar, bioquimicamente, um colágeno tipo I mais rígido (Schurch et al., 2006).

$\mathrm{Na}$ fase de remodelamento a ferida vai sendo preenchida com mais fibras de colágeno e começa a adquirir a aparência de massa fibrótica. Nos meses seguintes há a dissolução da granulação, a maioria das células desaparece e a matriz é constantemente alterada, com eliminação rápida da maior parte de fibronectina e acúmulo gradual de feixes de colágeno tipo I, que aumenta a força e a tensão da cicatriz (Morris, 2001). 
Segundo Engelhard et al. (1998) após o fechamento completo da ferida, quando micro-organismos já foram eliminados os linfócitos constituem o subsistema mais abundante em feridas humanas. Os linfócitos não somente são efetores imunes, mas produtores dos fatores de crescimento (Blotnik et al., 1994).

A resolução completa da ferida, somente é considerada depois de concluída a maturação e remodelação da matriz extracelular, este processo ocorre lentamente levando muitos meses ou anos e mesmo assim, uma cicatriz cutânea completamente madura possui apenas $70 \%$ da resistência da pele normal (Balbino et al., 2005).

\subsection{Enxertos de pele humana}

A enxertia de pele é frequentemente usada em reconstruções após remoção de neoplasias malignas cutâneas. No entanto, também está indicada para substituir o tecido perdido em queimaduras, dilacerações e cobertura de úlceras crônicas que não cicatrizam. Na prática dermatológica os autoenxertos são os mais empregados por sua comodidade, segurança, baixo custo e capacidade de atuação como cobertura definitiva (Lofêgo-Filho et al., 2006).

A cobertura temporária das feridas com pele cadavérica ou, ainda, pele animal, é de reconhecido valor em grandes queimados e pode ser usada com o mesmo sucesso em cirurgias dermatológicas e reconstrutivas. Sua aplicação promove oclusão da ferida, e assim o ambiente permanece úmido, tendo sua granulação, neovascularização e consequentemente cicatrização aceleradas (Kreis et al., 1992; Davis et al., 2000; Lofêgo-Filho et al., 2006).

O uso de aloenxertos de pele cadavérica é mais seguro e economicamente viável do que outras coberturas biológicas temporárias, como xenoenxerto porcino e membrana amniótica. O aloenxerto apresenta rápida aderência e menor potencial de antigenicidade em comparação com os demais (Obeng et al., 2001).

Essas coberturas temporárias muitas vezes são usadas com o intuito de preparar o leito da ferida para uma cobertura definitiva. Sobre áreas avasculares, como defeitos sobre ossos e cartilagem, esses enxertos aumentam dramaticamente a formação do tecido de granulação, aumentando a possibilidade de integração de um enxerto autólogo sequencial (Lofêgo-Filho et al., 2006). 


\subsection{Camundongos Nude}

Nos camundongos Nude a pele é mais delgada e constituída por duas camadas distintas, a epiderme e a derme, estas camadas apresentam diferenças peculiares. A epiderme é constituída somente por três a quatro camadas de células com camada córnea mais fina. A derme não é diferenciada em derme papilar e reticular como ocorre em humanos, não sendo normalmente encontradas células inflamatórias (McGow et al., 1987).

Estes animais, mostram um processo de reparação sem quase nenhuma cicatriz visível, assemelhando-se ao processo de reparação em fetos de mamíferos pela expressão de altos níveis de ácido hialurônico, baixo nível de colágeno, baixo nível de inflamação, baixo nível de citocinas pró-inflamatórias, fator de crescimento derivado de plaquetas (PDGF- $\beta$ ), e fator de crescimento transformante (TGF- $\beta 1$ ) e ausência de linfócitos T (Colwell et al., 2003; Dang et al., 2003). Estes animais apresentam o timo rudimentar ou total ausência dele, o que faz que os animais tenham deficiência na produção de linfócitos $T$, em consequência da deficiência de linfócitos $T$, os animais não rejeitam transplantes de outras linhagens ou de outras espécies e são suscetíveis a infecções (Foster et al., 1983; Andrade et al., 2002).

\subsection{Comportamento dos enxertos humanos utilizados em camundongos atímicos}

Para este tipo de enxerto os tecidos são processados em bancos de tecidos, onde se pode empregar a radiação ionizante como método de esterilização (Bringel, 2011).

A utilização de pele humana transplantada para o dorso de camundongos atímicos já foi descrito anteriormente e foi mostrado ser um método eficaz para examinar a cicatrização da pele humana "in vivo". Estudos imunohistoquímicos destes modelos têm mostrado que estes enxertos mantêm as características morfológicas, imunológicas e funcionais da pele humana (Démarchez et al., 1987; Reed et al., 1973).

Após a injúria tecidual, a reparação de feridas em camundongos Nude, que receberam transplante de pele humana, mimetiza o processo observado em humanos. Desse modo, a utilização de camundongos Nude representa uma 
ferramenta valiosa para o estudo da reparação, uma vez que sem comparação "in vivo", não seria permitido o estudo clinico em humanos (Démarchez et al., 1987).

\subsection{Radiações e sua absorção pelos materiais}

O interesse inicial nas radiações esta relacionado com as séries de transformações do urânio, tório e actínio. Este interesse foi estendido às informações que as radiações dão sobre o núcleo e as mudanças de energia em suas transformações. Medidas precisas das energias das radiações emitidas por radionuclídeos naturais levaram à ideia de estados nucleares de energia análogos aos estados atômicos de energia e o estudo das radiações emitidas tanto pelos radionuclídeos naturais como artificiais resultou no acúmulo de uma grande quantidade de informações sobre níveis nucleares. Teorias da emissão a (alfa), radiação $\beta$ (beta) e radiação y (gama) foram desenvolvidas, e a combinação de conhecimentos experimentais e teóricos destes processos forma um grande ramo da física nuclear (Dahlan, 2001).

Três processos são os principais responsáveis pela absorção de raios $ү:: 1$ ) absorção fotoelétrica, 2) espalhamento de Compton pelos elétrons em átomos, e 3) produção de pares elétrons-pósitrons como um resultado da interação entre raios y e os campos elétricos dos núcleos atômicos (Dahlan, 2001).

\subsubsection{Física das radiações}

Pode ser demonstrado segundo Kaplan (1983) que a radiação a consiste de dois prótons e dois nêutrons, semelhante a um núcleo de hélio. Quando se aplica um campo eletromagnético, essas partículas são desviadas para o pólo negativo, denotando sua carga positiva. Já a radiação $\beta$ é formada por um elétron e é desviada para o pólo positivo, o que demonstra que esta possui carga negativa. $A$ radiação $\mathrm{y}$ não é desviada pelo campo eletromagnético por não possuir carga elétrica. Desta maneira, as radiações $\alpha$ e $\beta$ são chamadas de corpusculares e a radiação y é dita eletromagnética.

Mostrou-se que as três radiações não são emitidas simultaneamente por todas as substâncias radioativas. Alguns elementos emitem partículas $\alpha$, outros emitem partículas $\beta$, enquanto que os raios $y$ acompanham algumas vezes uma e algumas vezes a outra. $O$ estudo químico detalhado das substâncias radioativas mostrou que cada substância é um elemento, e que sua radioatividade é causada 
por uma desintegração espontânea dos átomos radioativos em outros átomos (Kaplan, 1983).

De acordo com Kaplan (1983) a radiação ionizante é definida como uma forma de radiação que tem energia suficiente para expulsar elétrons dos átomos e moléculas de forma a convertê-los em íons. Promover reações desse tipo conduz à formação de radicais livres, que são, normalmente, altamente radioativos, e que eventualmente levam a reações químicas.

A radiação ionizante pode ser obtida a partir de duas diferentes fontes: a) radioisótopos e b) máquinas de descargas elétricas. Os mais comuns radioisótopos usados comercialmente são o cobalto-60 $\left({ }^{60} \mathrm{Co}\right)$ e o césio-137 $\left({ }^{137} \mathrm{Cs}\right)$ (Dahlan, 2001).

\subsubsection{Esterilização}

A esterilização é definida como o processo ou ato de inativar todas as formas de vida, em especial os micro-organismos. A cinética de inativação microbiana é de natureza exponencial, o que significa que sempre existe a probabilidade de sobrevivência de alguns micro-organismos, independentemente da magnitude do tratamento empregado (Block, 1991).

Segundo Singh et al. (2016) é necessário um processo de esterilização com alta eficiência para que ocorra a inativação de micro-organismos, desta forma, garantindo a segurança dos tecidos utilizados para aloenxerto.

Durante a retirada, processamento ou armazenamento do tecido, pelos bancos de tecidos, estes podem ser infectados por micro-organismos e, mesmo levando em consideração que estes procedimentos são executados sob condições assepticas, a possibilidade de transmissão viral, fúngica ou bacteriana originária do doador não pode ser descartada, e desta forma, os aloenxertos de tecidos devem ser esterilizados (Dziedzic-Goclawska, 2001; Singh et al., 2016).

\subsubsection{Esterilização por radiação ionizante}

De acordo com Dziedzic-Goclawska et al. (2005).o termo radiação ionizante é usado para todas as radiações com excesso de energia e capazes de produzir cascatas de ionização na matéria. A variação da energia característica da radiação ionizante começa com cerca de $103 \mathrm{MeV}$ e alcança seu limite superior com cerca de $30 \mathrm{MeV}$. Entretanto, para evitar qualquer indução de 
radioatividade, a qual pode ocorrer se a energia de radiação incidente ultrapassar $12 \mathrm{MeV}$, o uso de energias de radiação acima de $10 \mathrm{MeV}$ é proibido para esterilização de tecidos biológicos. Na prática, somente raios gama produzidos por ${ }^{60} \mathrm{Co}$, os quais possuem níveis de energia de $1,17 \mathrm{MeV}$ e 1,33 Mev, e feixes de elétrons acelerados (8-10 MeV) são usados.

A esterilização por radiação ionizante tem grande capacidade de penetração na matéria e sua eficiência em inativar micro-organismos, sem alterar muito a temperatura, permite que o processo todo ocorra com os matérias biológicos previamente fechados, prevenindo a recontaminação.

Usualmente, a dose utilizada é de $25 \mathrm{kG}$ para esterilização de tecidos biológicos, objetivando a inativação de fungos e bactérias. Levando-se em consideração que altas doses de radiação ionizante (acima de 40 a 50 kGy) podem provocar varias alterações químicas e físicas, podendo diminuir também as propriedades biomecânicas, uma alternativa deve ser considerada para minimizar o risco de transmissão de infecções virais, como uma melhor seleção de doadores (Dziedzic-Goclawska, 2001).

Porém, o Banco de Tecidos Central em Warsaw utiliza, desde 1963, doses de $33 \mathrm{kGy} \pm 10 \%$ para a esterilização dos tecidos. Essa mesma dose é usada em outras unidades regionais de Bancos de Tecidos na Polônia (Dziedzic-Goclawska et al., 2005).

\subsubsection{Inativação de patógenos por radiação ionizante}

Segundo Dziedzic-Goclawska (2001), as estruturas sensíveis à radiação ionizante nos micro-organismos são os ácidos nucléicos (DNA - ácido desoxirribonucleico e RNA - ácido ribonucleico). O dano pode ser causado diretamente ou indiretamente, por meio da radiólise da água e pela produção de radicais hidróxidos $(\cdot \mathrm{OH})$, que são altamente reativos e possuem vida curta. $\mathrm{Na}$ presença de água predomina o mecanismo indireto. A presença de oxigênio potencializa o dano. Peróxidos, assim como seus radicais, são produzidos pela reação do oxigênio com os radicais hidróxidos, provocando diversos danos no DNA. Podem ocorrer também entrecruzamentos entre as fitas e danos nas bases ou nas moléculas de açúcar do DNA, o que inibe sua síntese e gera erro na síntese das proteínas, levando à morte celular. 


\section{MATERIAIS E MÉTODOS}

Todas as amostras utilizadas no presente estudo são provenientes do trabalho de doutorado da Dra. Fabiana de Andrade Bringel com (Aprovação do Comitê Ética em Pesquisa Animal, parecer - Projeto № 14/CEPA-IPEN/SP, São Paulo, 08 de Março de 2007 e aprovação da Comissão de Ética em Pesquisas com seres Humanos do Instituto de Ciências Biomédicas da Universidade de São Paulo, parecer - 772/CEP, São Paulo, 11 de Abril de 2007). Onde foi utilizada a caracterização morfológica de pele humana e de camundongo Nude, avaliação por imagem de tomografia de coerência óptica, microscopia de luz nas histologias dos tecidos enxertados e avaliação biomecânica dos tecidos. As amostras histológicas emblocadas em parafina e os tecidos corados com a técnica de HE foram previamente preparados, a partir da descrição detalhada encontrada na tese de doutorado de (Bringel, 2011).

\subsection{Divisões dos grupos para análise dos tecidos}

Os tecidos utilizados no presente estudo foram divididos em três grupos de doses de radiação; tecidos não irradiados, irradiados com dose de 25 kGy e $50 \mathrm{kGy}$, divididos em três datas de eutanásia no $3^{\circ}, 7^{\circ}$ e $21^{\circ}$ dias depois da enxertia de pele humana. 


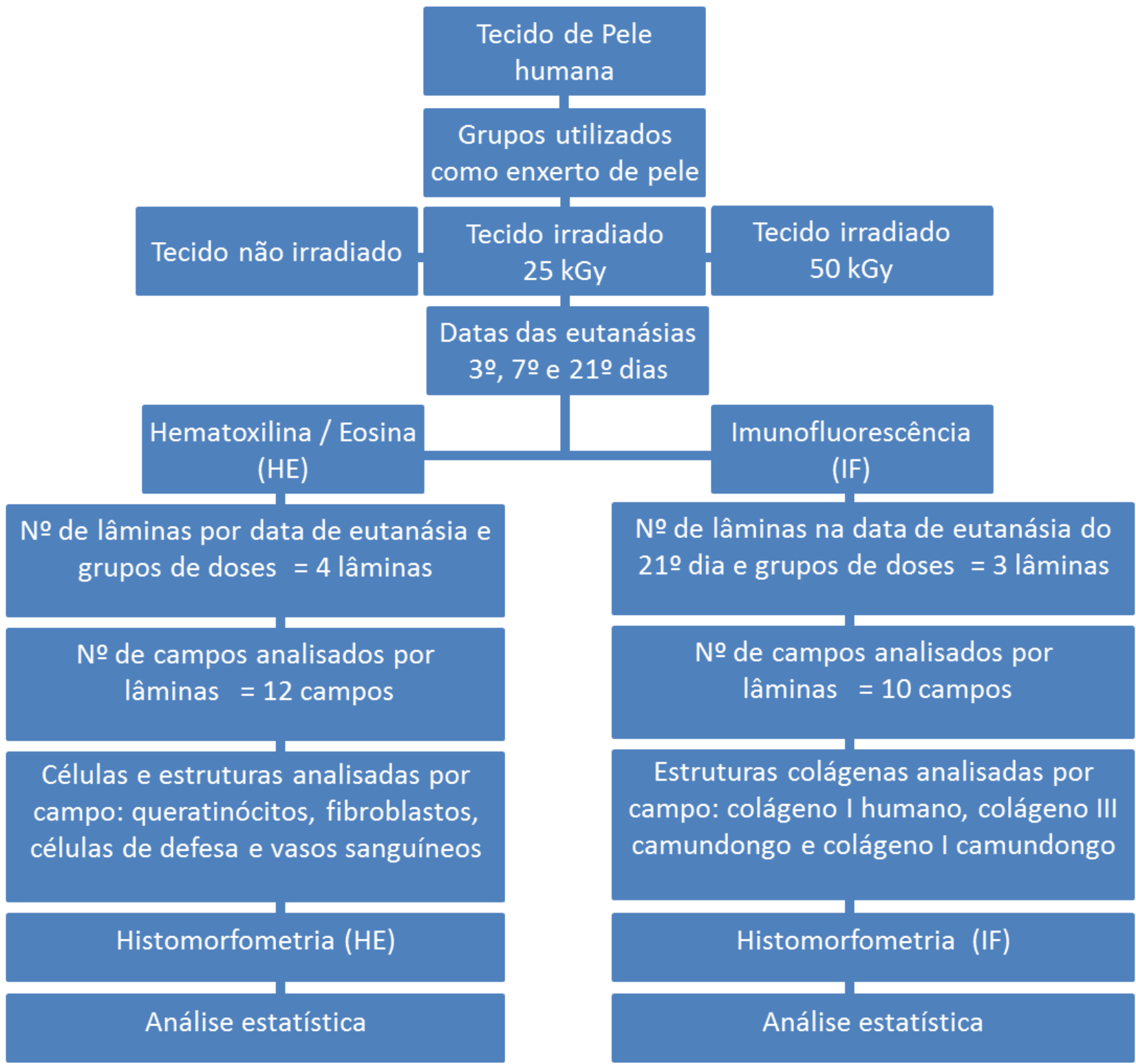

Figura 4 - Fluxograma do procedimento de trabalho das lâminas com tecidos coradas com HE e Imunofluorescência, contendo as divisões por dose de irradiação mais grupo não irradiado; datas das eutanásias; quantidades de lâminas e número de campos analisados; estruturas e células quantificadas e análise estatística.

\subsection{Distribuição celular e de vasos sanguíneos}

Foram utilizadas as lâminas histológicas contendo tecido animal e respectivo enxerto de pele humana, previamente coradas pela técnica de $\mathrm{HE}$, para a determinação da distribuição e quantificação dos diferentes tipos celulares e vasos sanguíneos. Para tanto, foram analisadas quatro lâminas de cada grupo de dose mais o grupo não irradiado e nas diferentes datas de eutanásia, desta forma obteve-se o total de uma lâmina por animal e quatro lâminas por grupo e data. 
Como pode ser visto na FIG. 5 a linha tracejada na cor verde mostra a divisão entre tecido do camundongo normal e tecido em estágio de reparação, todas as análises dos campos foram feitas dentro da linha tracejada, pois o intuito deste trabalho foi quantificar somente o tecido que esta em estágio de reparação.

Foram analisadas as quantidades de células por campo, sendo que cada lâmina foi dividida em três áreas: duas extremidades e centro do tecido. Com seis campos nas extremidades e seis campos no centro do tecido, com um total de 12 campos por lâmina, foram utilizadas quatro lâminas por grupo de dose gerando um total de 48 campos por data e dose, totalizando 432 campos analisados.

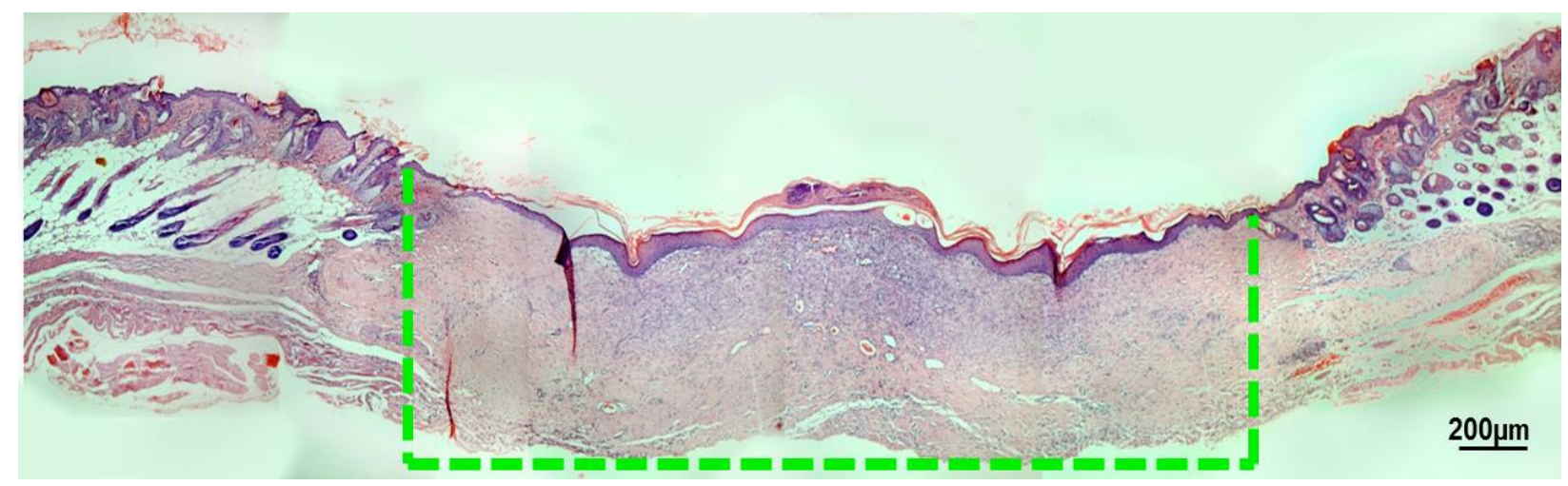

Figura 5 - Corte histológico do tecido de camundongo enxertado com pele humana, eutanásiado no $21^{\circ}$ dia após enxertia. A linha tracejada na cor verde mostra a divisão do tecido em estagio de reparação. Imagem montada via programa Adobe Photoshop CS6. Microscopia óptica HE. Aumento de 100X.

\subsubsection{Histomorfometria das células e estruturas dos tecidos corados com HE}

A análise histomorfométrica foi realizada para quantificar, queratinócitos, fibroblastos, células de defesa e vasos sanguíneos, feita a contagem por campo nas regiões do reparo (FIG. 6 e FIG. 7), utilizando o software, Image-Pro Plus 6.0 (Media Cybernetics, Rockville, USA), o sistema consiste de um microscópio Nikon Eclipse E600, integrado a uma câmera digital DP72 (Olympus, Tóquio, Japão), localizado no Instituto de Ciências Biomédicas ICB-USP. 


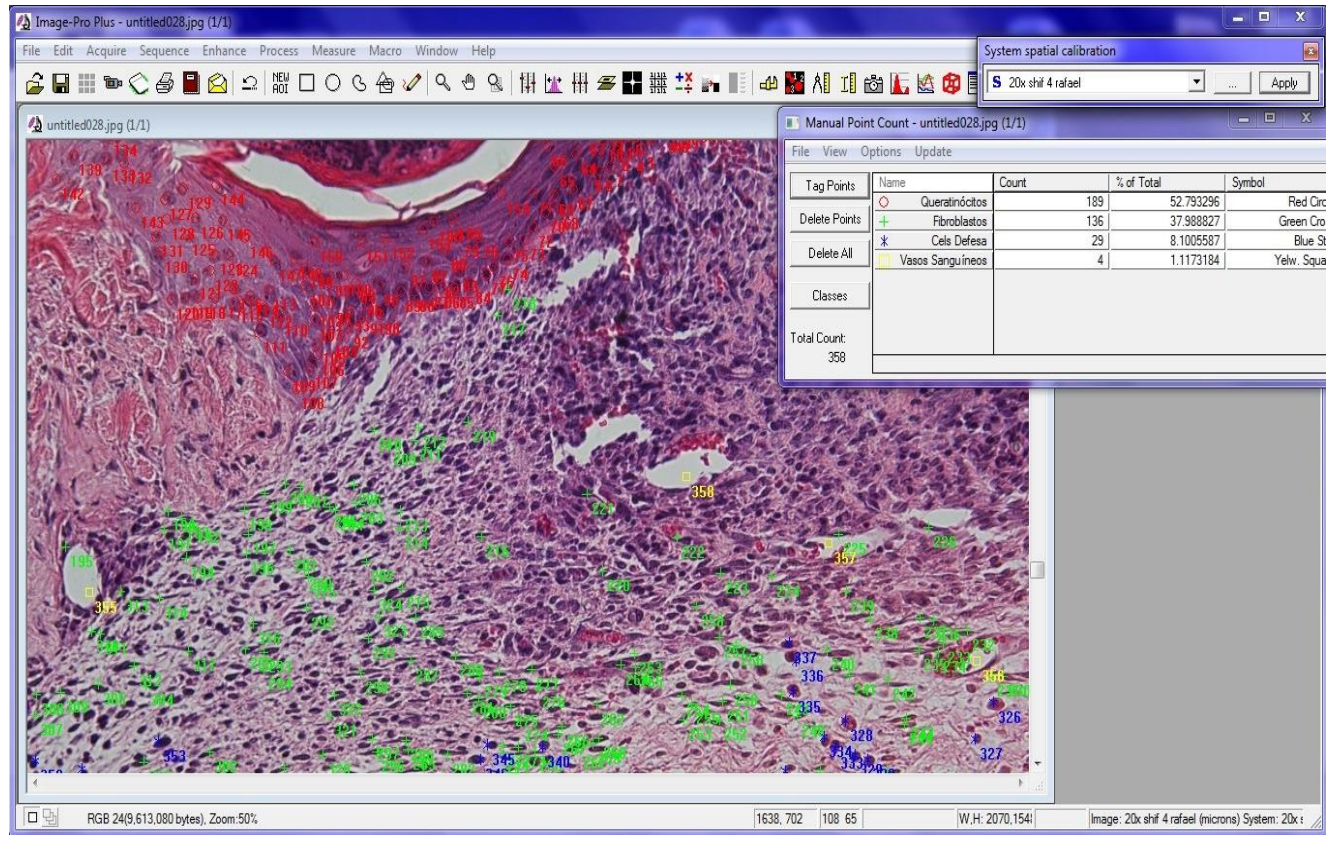

Figura 6 - llustração representativa da avaliação das células e estruturas na derme de camundongo, por análise de imagem. Em vermelho (queratinócitos), verde (fibroblastos), azul (células de defesa), amarelo (vasos sanguíneos) corado com HE, quantificação pelo software Image-Pro Plus 6.0.
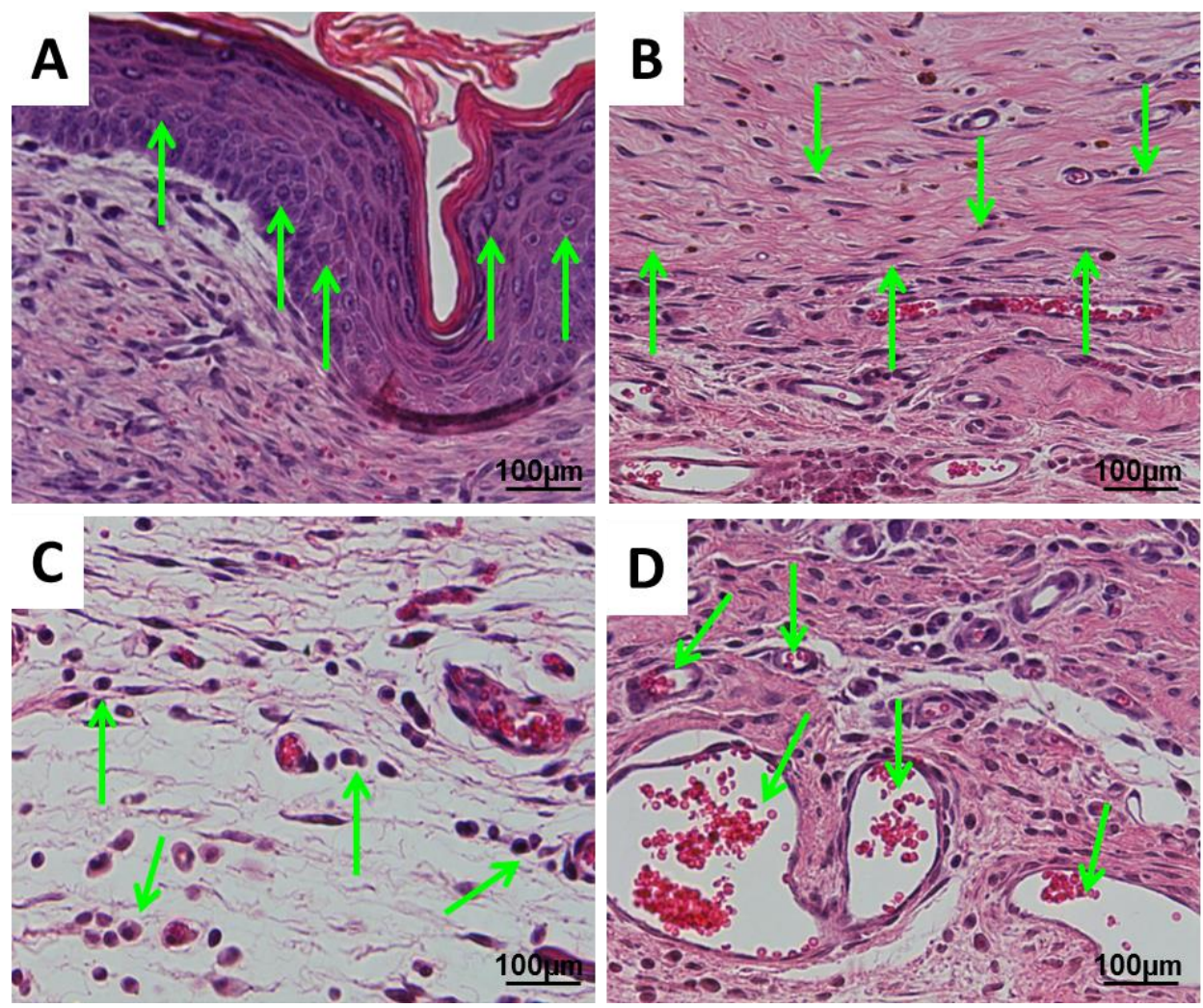

Figura 7 - llustração representativa das imagens dos tecidos, vistas ao microscópio, para avaliação das células e vasos sanguíneos. As setas em verde fluorescente indicam: A) Queratinócitos, B) Fibroblastos, C) Células de Defesa, D) Vasos Sanguíneos. Todas as imagens estão em um aumento de $200 \mathrm{X}$. 


\subsubsection{Métodos utilizados nas analises estatísticas dos dados de quantificação celular e vasos sanguíneos}

Os dados foram obtidos no programa Image-Pro Plus 6.0 e analisados pelo programa estatístico Statistica v.7 (Statsoft, EUA). Para todas as variáveis foram calculadas medidas de estatística descritiva, como média, mediana, desvio padrão e intervalo interquartílico normalizado (IQN).

Para isso, os valores médios de cada animal ( $n=4$ animais) foram calculados e inseridos em linhas, ao passo que as respostas foram alocadas nas colunas, totalizando 432 campos experimentais. No intuito de verificar diferenças estatísticas para cada fator do estudo (tempo de cicatrização, dosagem de radiação e localização da análise - extremidade e centro), a análise de variâncias unifatorial (ANOVA) foi aplicada, ao passo que análise de variâncias multifatorial (MANOVA) foi empregada para avaliar fatores combinados, ou seja, tempo vs radiação, tempo vs localização, localização vs radiação, e tempo vs localização vs radiação. O teste de Tukey foi aplicado para avaliar diferenças nos valores médios. Análise de correlação linear foi calculada para avaliar o grau de associação entre as variáveis de resposta em função da dosagem de radiação e o tempo de cicatrização. Para as análises inferenciais, levou-se em consideração um valor $\alpha=5 \%$ para rejeição da hipótese de nulidade (Granato et al., 2014; Zielinski et al., 2014).

\subsection{Cortes dos tecidos para imunofluorescência}

Os cortes dos tecidos foram realizados no Instituto de Pesquisas Energéticas e Nucleares no Centro de Biotecnologia (CB IPEN-CNEN/SP), em micrótomo Leica RM2255 (Leica Microsystens, Wetzlar, Alemanha), numa espessura de $4 \mu \mathrm{m}$, sendo aderidos em lâminas silanizada (Knittel Glass, Alemanha), para as reações de imunofluorescência.

\subsubsection{Imunofluorescência para colágeno dos tipos I e III no tecido cutâneo}

Para a imunofluorescência do colágeno do tipo I humano e do colágeno do tipo III e I de camundongo em tecido cutâneo de camundongos Nude, submetidos a enxerto de pele humana, a reação foi iniciada pela desparafinização dos cortes, pela imersão das lâminas em xilol aquecido, a $60^{\circ} \mathrm{C}$, por 40 minutos, e dois banhos de 10 minutos em xilol em temperatura ambiente. A reidratação dos 
cortes foi realizada por sucessivas lavagens em álcool etílico em concentrações decrescentes (100\% - 75\%), seguido de lavagem em água corrente, por 10 minutos, um banho em água destilada e 10 minutos em tampão fosfato de sódio, pH 7,4 (PBS). Para a exposição e recuperação de sítios antigênicos, os cortes foram submetidos à digestão com pepsina da mucosa gástrica de suíno (Sigma Chemical Co., St. Louis, MO, USA; 10000 UTI/ml) na concentração de 8 mg/ml em ácido acético $0,5 \mathrm{~N}$, por 30 minutos, a $37^{\circ} \mathrm{C}$. Ao término desta incubação os cortes foram submetidos a um ciclo de lavagens com PBS, por três vezes de 10 minutos, e os sítios inespecíficos bloqueados com BSA (Soro Albumina Bovina, do inglês, Bovine Serum Albumin) a $5 \%$, durante 30 minutos, em temperatura ambiente. As lâminas foram incubadas durante uma noite a $4^{\circ} \mathrm{C}$ com os seguintes anticorpos policlonais, diluídos em PBS: anticorpo de coelho anti-colágeno I humano, 600-401-103-0.5 (Rockland, Gilbertsville, PA) (1:50); anticorpo de coelho anti-colágeno I de camundongo, AB21286 (Abcam, Cambridge, UK) (1:40); anticorpo de coelho anti-colágeno III de camundongo, LS-C41838 (LSBio, Seattle, WA) (1:200) (TAB. 1). Após este período, os cortes foram lavados em PBS, com Tween 20 a $0,05 \%$, por três vezes de 10 minutos, e incubados por 60 minutos com o anticorpo de cabra anti-lgG de coelho, conjugado ALEXA FLUOR 488 (Thermo Fisher Scientifc, Rockford, IL) diluído 1:200 em solução de PBS, contendo azul de Evans 0,006\% (Sigma-Aldrich, Saint Louis, MO) (TAB. 1). Por fim, as lâminas foram novamente lavadas, por cinco vezes com PBS com Tween 20 a $0,05 \%$, montadas com solução de glicerina tamponada e analisadas em microscópio de fluorescência (Olympus BX-51, Olympus Co, Tokyo, Japan) na Disciplina de Reumatologia do Departamento de Clínica Medicina da Faculdade de Medicina - FMUSP. 
Tabela 1 - Anticorpos utilizados em imunofluorescência

\begin{tabular}{|c|c|c|c|}
\hline Marcador & Anticorpo primário & Diluição & Anticorpo secundário \\
\hline $\begin{array}{c}\text { COL I } \\
\text { humano }\end{array}$ & $\begin{array}{l}\text { Anti-COL-I, policlonal } \\
\text { de coelho. (Rockland, } \\
\text { Gilbertsville, PA) }\end{array}$ & $1: 50$ & $\begin{array}{c}\text { Anticorpo de cabra } \\
\text { anti-lgG de coelho. } \\
\text { ALEXA FLUOR 488, } \\
\text { (Thermo Fisher } \\
\text { Scientifc, Rockford, IL) }\end{array}$ \\
\hline $\begin{array}{c}\text { COL III } \\
\text { camundongo }\end{array}$ & $\begin{array}{l}\text { Anti-COL-III, policlonal } \\
\text { de coelho (LSBio, } \\
\text { Seattle, WA) }\end{array}$ & 1:200 & $\begin{array}{c}\text { Anticorpo de cabra } \\
\text { anti-lgG de coelho. } \\
\text { ALEXA FLUOR 488, } \\
\text { (Thermo Fisher } \\
\text { Scientifc, Rockford, IL) }\end{array}$ \\
\hline $\begin{array}{c}\text { COL I } \\
\text { camundongo }\end{array}$ & $\begin{array}{l}\text { Anti-COL-I, policlonal } \\
\text { de Coelho. (Abcam, } \\
\text { Cambridge, UK) }\end{array}$ & $1: 40$ & $\begin{array}{c}\text { Anticorpo de cabra } \\
\text { anti-lgG de coelho. } \\
\text { ALEXA FLUOR 488, } \\
\text { (Thermo Fisher } \\
\text { Scientifc, Rockford, IL) }\end{array}$ \\
\hline
\end{tabular}

\subsubsection{Histomorfometria do colágeno dos tipos I humano e I III de camundongo no tecido cutâneo de camundongo Nude}

A análise histomorfométrica foi realizada para quantificar as fibras de colágeno I humano, colágeno I e III de camundongo, nas regiões da derme de camundongos Nude, submetidos a enxerto de pele humana, por meio de um sistema de análise de imagens. O sistema consiste de uma câmera fotográfica CCD Sony, acoplada a um microscópio Olympus BX51 (Olympus Co, Tokyo, Japan), a qual captura as imagens e as envia para o monitor por um sistema de digitalização (Oculus TCX, Coreco, Inc, St. Laurent, Quebec, Canada). As imagens foram processadas pelo software Image-Pro Plus 6.0. A análise foi realizada por observador, às cegas, sendo adquiridas seis imagens das extremidades e quatro imagens do centro de cada lâmina, com aumento de 200X para o colágeno I humano (FIG. 8), colágeno III de camundongo (FIG. 9) e, com aumento de 400X para o colágeno I de camundongo (FIG. 10). Utilizando-se os recursos do software Image-Pro Plus 6.0, a área total de cada campo analisado foi (FIG. 8A, 9A, 10A) demarcada em uma linha amarela tracejada e quantificada em $\mu \mathrm{m}^{2}$. As diversas tonalidades de verde fluorescente, identificam as fibras de colágeno I humano (FIG. 8B), colágeno III (FIG. 9B) e colágeno I (FIG. 10B) de camundongo, que para melhor visualização são transformadas, pelo programa, 
em coloração vermelha, possibilitando a quantificação da área fluorescente. A média da área imunomarcada, correspondente aos colágenos descritos acima, foi dividida pela média da área total analisada e o resultado final expresso em fração da área.
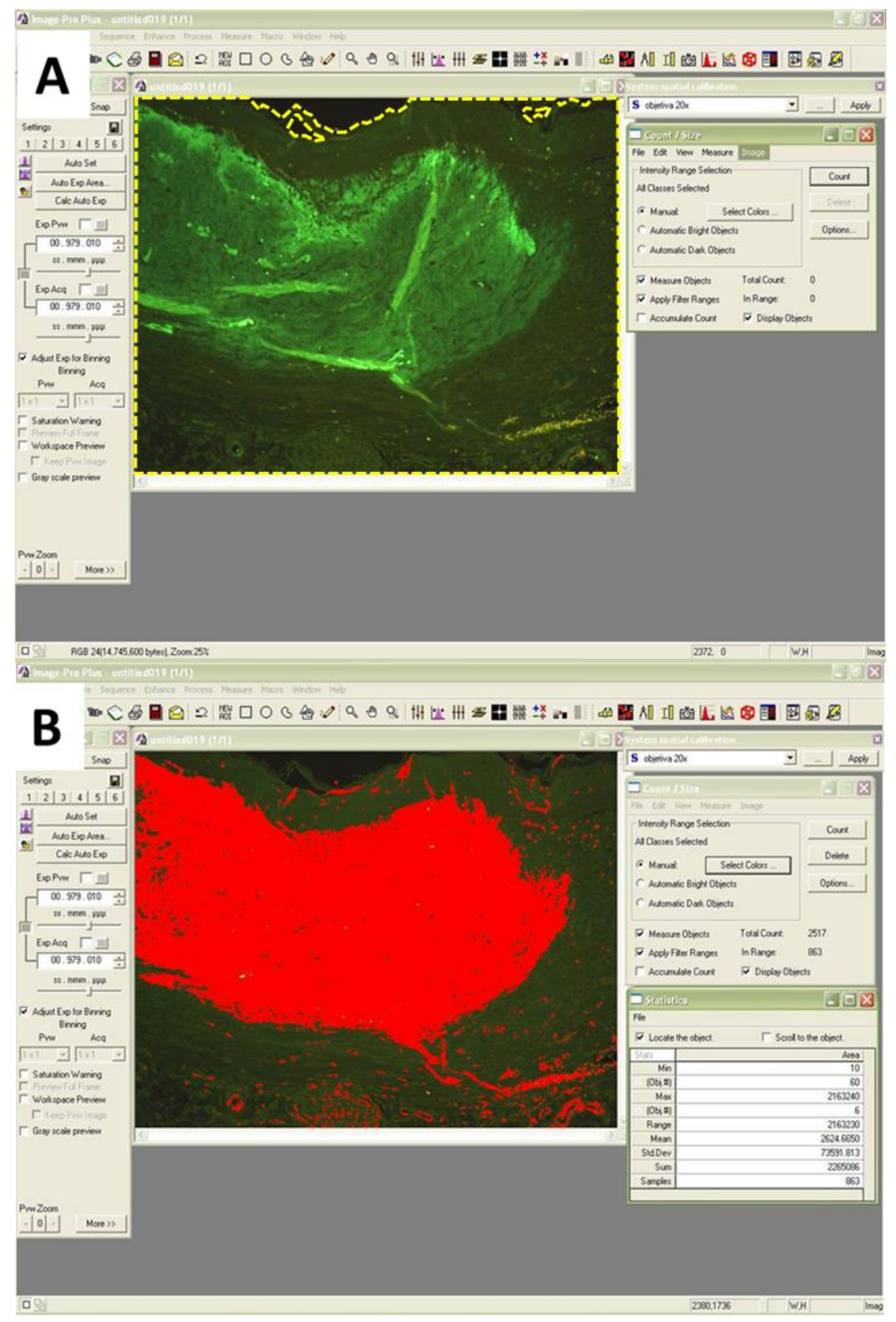

Figura 8 - Ilustração representativa da avaliação das fibras de colágeno I humano (verde fluorescente) na derme, por análise de imagem. A) A linha amarela tracejada delimita a área total do tecido, analisada em $\mu \mathrm{m} 2$. B) Em vermelho está demarcada a imunofluorescência, correspondente ao colágeno I humano, quantificada pelo software Image-Pro Plus 6.0. 


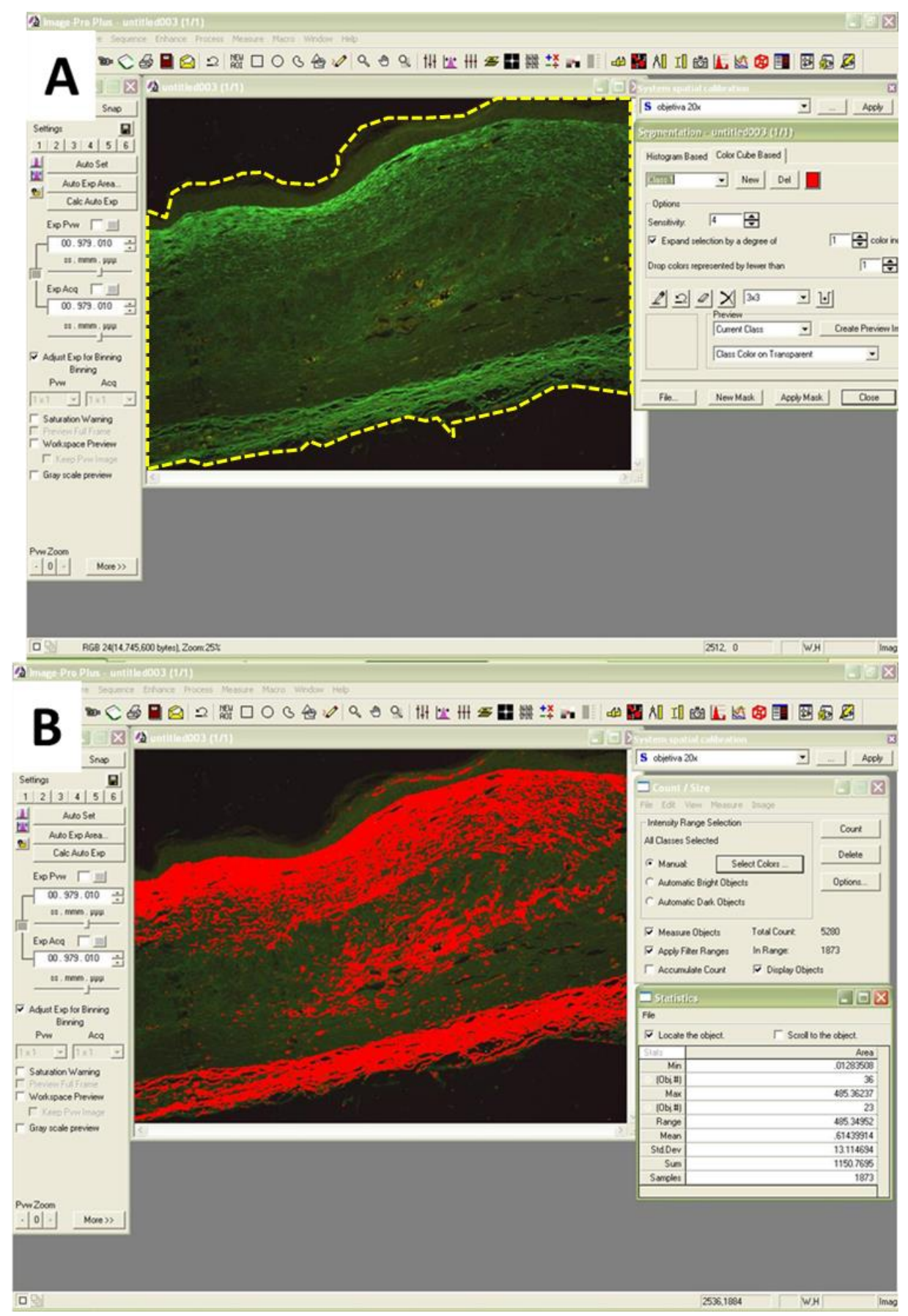

Figura 9 - Ilustração representativa da avaliação das fibras de colágeno III de camundongo (verde fluorescente) na derme, por análise de imagem. A) A linha amarela tracejada delimita a área total do tecido, analisada em $\mu \mathrm{m}^{2}$. B) Em vermelho está demarcada a imunofluorescência, correspondente ao colágeno III de camundongo, quantificada pelo software Image-Pro Plus 6.0. 

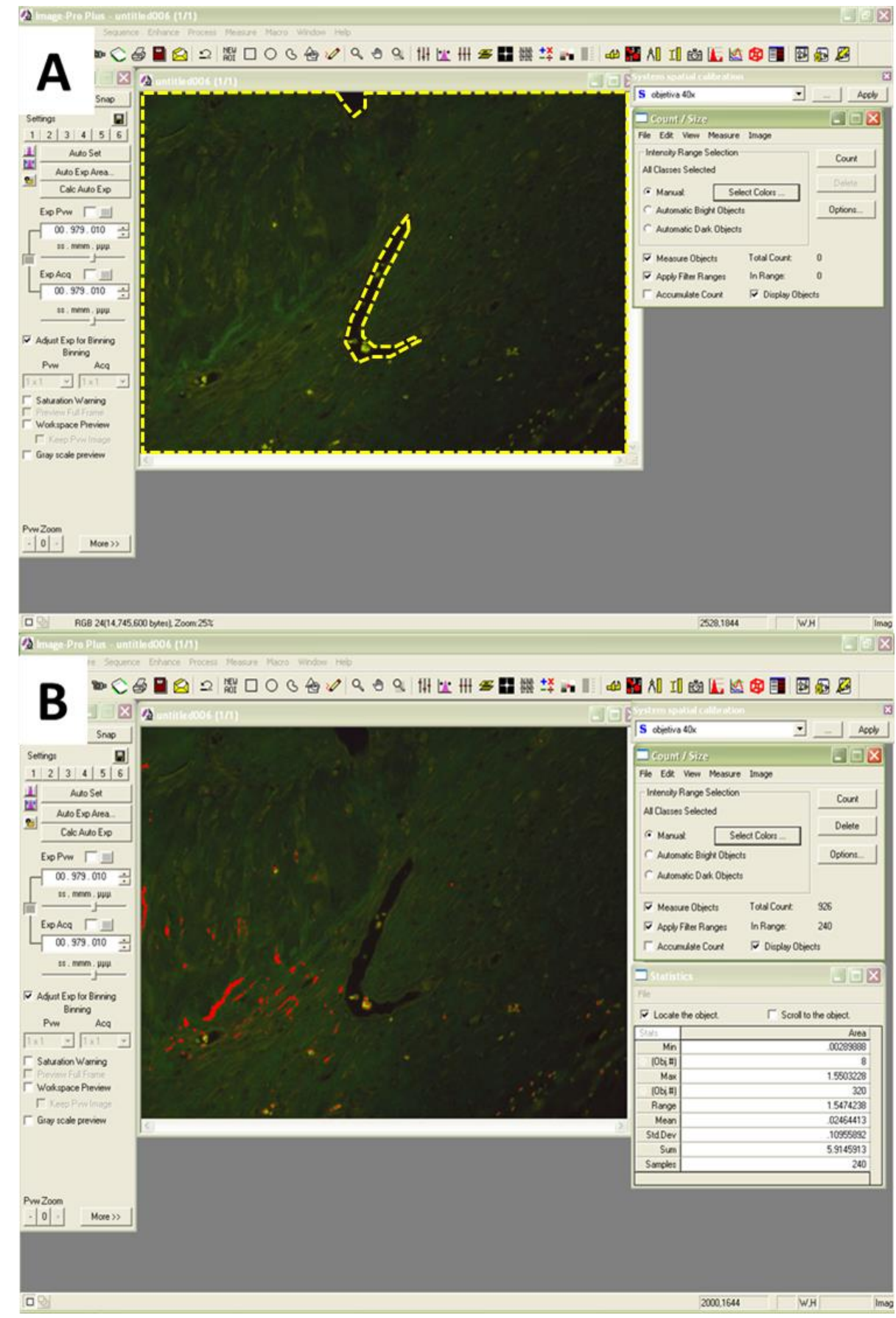

Figura 10 - Ilustração representativa da avaliação das fibras de colágeno I de camundongo (verde fluorescente) na derme, por análise de imagem. A) A linha amarela tracejada delimita a área total do tecido, analisada em $\mu \mathrm{m} 2$. B) Em vermelho está demarcada a imunofluorescência, correspondente ao colágeno I de camundongo, quantificada pelo software Image-Pro Plus 6.0. 
4.3.3 Métodos utilizados para as analises estatísticas dos dados da expressão de colágeno

Para os grupos contidos no tempo $\mathrm{t}=21$ dias, os valores médios obtidos de cada tecido, para cada variável, foram submetidos à análise de variâncias unifatorial (ANOVA) no objetivo de verificar se havia diferença estatisticamente significativa $(p<0,05)$ entre as doses de radiação empregadas, a quantidade de colágeno nos tecidos e a localização dividida em extremidade, centro e área total do tecido. Quando diferenças foram detectadas, ou seja, $p<0,05$, o teste de Tukey foi aplicado para a comparação das médias. Para as análises inferenciais, levouse em consideração um valor $\alpha=5 \%$ para rejeição da hipótese de nulidade (Granato et al., 2014). O software GraphPad Prism 5 foi empregado nesta análise estatística. 


\section{RESULTADOS}

\subsection{Distribuição celular e de vasos sanguíneos ao longo da regeneração tecidual}

Na FIG. 11 pode-se observar as alterações histológicas no enxerto de pele humana não irradiada, irradiada com 25 e 50 kGy nos camundongos submetidos a eutanásia no $3^{\circ}, 7^{\circ}$ e $21^{\circ}$ dia após enxertia. Os controles do tecido humano e do tecido animal íntegros e submetidos às mesmas doses de irradiação estão apresentados no APÊNDICE A.

No grupo com enxerto não irradiado, no $3^{\circ}$ dia foi observado que o tecido apresenta poucas células e a derme está estruturada (FIG. $11 \mathrm{~A}$ ). Já nos grupos com enxertos irradiados com 25 kGy (FIG. 11 D) e 50 kGy (FIG. 11 G) a derme está mais desestruturada formando sulcos. Nestes sulcos encontra-se uma grande quantidade de células, que também podem ser visualizadas na região mais profunda da derme.

No $7^{\circ}$ dia, no enxerto não irradiado (FIG. 11 B) pode ser observada uma separação entre a epiderme e a derme, com a presença de poucas células. Já os grupos com enxerto irradiado com 25 kGy (FIG. 11 E) e 50 kGy (FIG. 11 H) apresentam grande quantidade de células na derme e pouca frequência de vasos sanguíneos. Ainda, no grupo com enxerto irradiado com 25 kGy (FIG. 11 E) podese observar que a epiderme se encontra aderida à derme. Já no enxerto irradiado com 50 kGy (FIG. 11 H) observa-se um descolamento da epiderme com relação à derme.

No $21^{\circ}$ dia, o grupo com o enxerto não irradiado apresenta grande quantidade de células na região entre epiderme e derme, além da presença de vasos sanguíneos (FIG. 11 C) e os enxertos irradiados com 25 kGy (FIG. 11 F) e 50 kGy (FIG. 11 I) apresentam menor quantidade de células e melhor remodelamento da derme. 

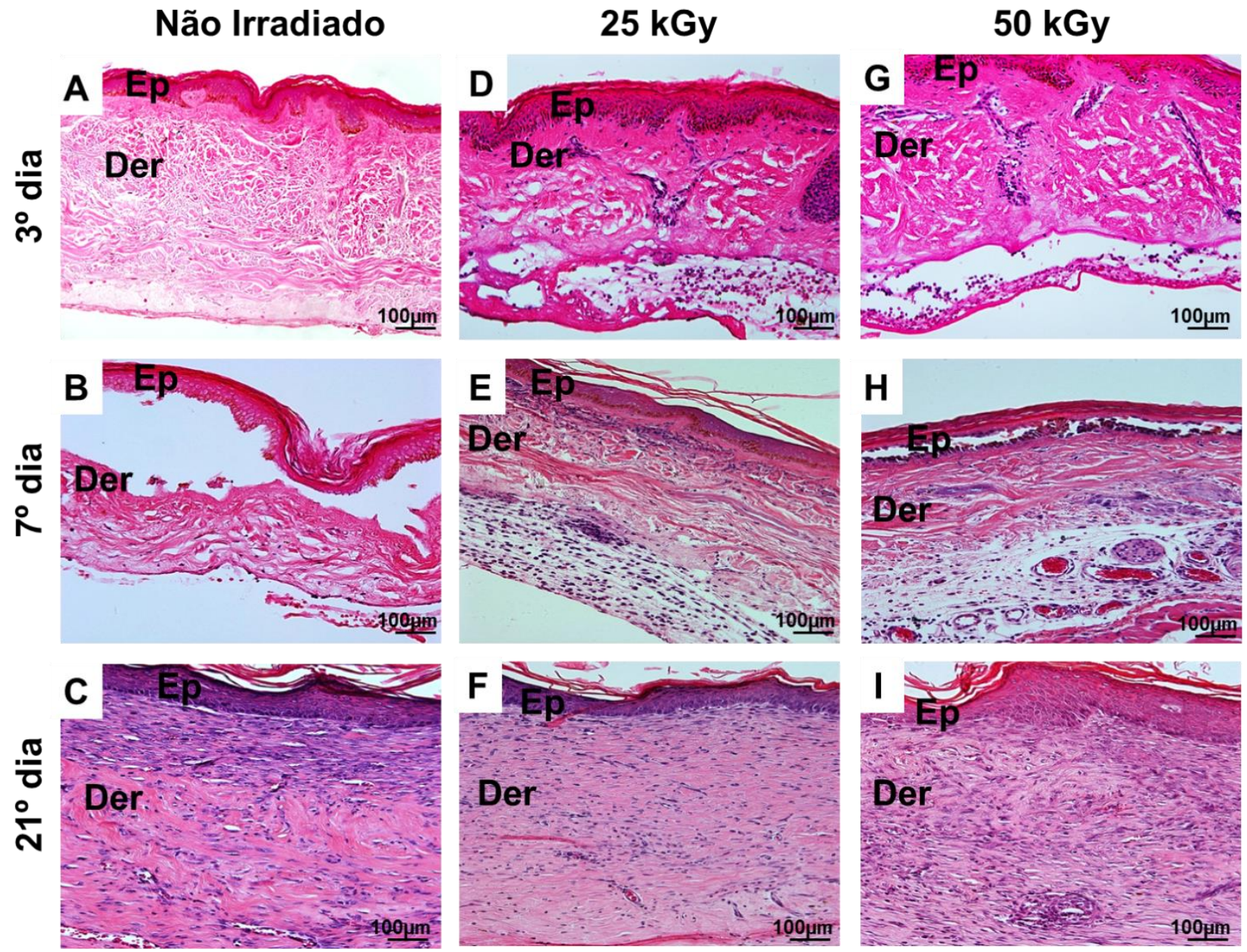

Figura 11 - Fotomicrográfia dos cortes histológicos dos tecidos analisados, corados com HE. Representada a epiderme por (Ep) e por (Der) a região da derme em reparação. Todas as imagens estão em um aumento de $100 \mathrm{X}$.

\subsubsection{Quantificação celular e de vasos sanguíneos ao longo da regeneração} tecidual

O número de queratinócitos, fibroblastos, células de defesa e vasos sanguíneos foi avaliado pelo programa Image-Pro Plus 6.0, por campo de tecido cutâneo, com aumento de $100 \times$ (FIG. 11). Foram analisadas as regiões da extremidade e do centro nos enxertos irradiados ( 25 e 50 kGy) e não irradiados e os resultados obtidos encontram-se na TAB. 2.

No $3^{\circ}$ dia, não foram encontrados queratinócitos e vasos sanguíneos, tanto no grupo não irradiado, como nos grupos irradiados. Em relação aos fibroblastos e às células de defesa, foi observado maior crescimento nos grupos irradiados (TAB. 2). Já no $7^{\circ}$ dia, há crescimento de queratinócitos apenas nas extremidades do enxerto para os três grupos. Os fibroblastos estão em maior proporção nas extremidades dos grupos irradiados e as células de defesa destacam-se, nas 
duas regiões, no grupo irradiado a 25 kGy. Já os vasos sanguíneos estão principalmente localizados na região das extremidades nos três grupos (TAB. 2). No $21^{\circ}$ dia, os queratinócitos estão presentes nos três grupos, com destaque para a quantidade e distribuição no grupo com enxerto irradiado a 25 kGy. Os fibroblastos também apresentam o mesmo padrão de homogeneidade, na sua distribuição, em todos os grupos. Já as células de defesa foram encontradas em maior quantidade no enxerto irradiado a 50 kGy na região do centro, apesar se observar diferenças entre extremidade e centro em todos os grupos. Os vasos sanguíneos, no $21^{\circ}$ dia estavam concentrados principalmente no centro do enxerto nos três grupos (TAB. 2).

Tabela 2 - Distribuição e quantidade de queratinócitos, fibroblastos, células de defesa e vasos sanguíneos nos enxertos não irradiados e irradiados a $25 \mathrm{kGy}$ e 50 kGy nos grupos com 3ำ $7^{\circ}$ e $21^{\circ}$ dias de enxertia

\begin{tabular}{|c|c|c|c|c|c|c|}
\hline $\begin{array}{l}\text { Tempo } \\
\text { (dias) }\end{array}$ & $\begin{array}{c}\text { Radiação } \\
\text { (kGy) }\end{array}$ & $\begin{array}{c}\text { Regiões } \\
\text { Tecido }\end{array}$ & Queratinócitos & Fibroblastos & $\begin{array}{c}\text { Células de } \\
\text { Defesa }\end{array}$ & $\begin{array}{c}\text { Vasos } \\
\text { Sanguíneos }\end{array}$ \\
\hline 3 & 0 & Extremidade & 0 & $25^{\mathrm{C}}$ & $14^{\mathrm{C}}$ & 0 \\
\hline 3 & 0 & Centro & 0 & $27^{c}$ & $11^{\mathrm{C}}$ & 0 \\
\hline 3 & 25 & Extremidade & 0 & $33^{c}$ & $44^{b, c}$ & 0 \\
\hline 3 & 25 & Centro & 0 & $38^{c}$ & $50^{b, c}$ & 0 \\
\hline 3 & 50 & Extremidade & 0 & $30^{c}$ & $74^{a, b, c}$ & 0 \\
\hline 3 & 50 & Centro & 0 & $40^{c}$ & $39^{b, c}$ & 0 \\
\hline 7 & 0 & Extremidade & $83^{a, b, c}$ & $26^{c}$ & $95^{\mathrm{a}, \mathrm{b}, \mathrm{c}}$ & $4^{b, c}$ \\
\hline 7 & 0 & Centro & 0 & $17^{c}$ & $78^{a, b, c}$ & $1^{b, c}$ \\
\hline 7 & 25 & Extremidade & $91^{\mathrm{a}, \mathrm{b}, \mathrm{c}}$ & $39^{b, c}$ & $105^{a, b}$ & $5^{b, c}$ \\
\hline 7 & 25 & Centro & 0 & $27^{c}$ & $116^{a, b}$ & $2^{b, c}$ \\
\hline 7 & 50 & Extremidade & $87^{a, b, c}$ & $43^{b, c}$ & $60^{a, b, c}$ & $3^{b, c}$ \\
\hline 7 & 50 & Centro & 0 & $20^{c}$ & $61^{\mathrm{a}}, \mathrm{b}, \mathrm{c}$ & $1^{b, c}$ \\
\hline 21 & 0 & Extremidade & $93^{a, b, c}$ & $94^{a}$ & $47^{b, c}$ & $9^{a, b, c}$ \\
\hline 21 & 0 & Centro & $56^{b, c, d}$ & $92^{a}$ & $77^{a, b, c}$ & $19^{a}$ \\
\hline 21 & 25 & Extremidade & $127^{a, b}$ & $86^{a}$ & $60^{a, b, c}$ & $8^{a, b, c}$ \\
\hline 21 & 25 & Centro & $108^{a, b}$ & $114^{a}$ & $91^{\mathrm{a}}, \mathrm{b}, \mathrm{c}$ & $11^{a, b, c}$ \\
\hline 21 & 50 & Extremidade & $152^{a}$ & $79^{a, b}$ & $43^{b, c}$ & $5^{b, c}$ \\
\hline 21 & 50 & Centro & $24^{d, c}$ & $78^{a, b}$ & $138^{a}$ & $14^{a, b}$ \\
\hline
\end{tabular}

Resultados estatisticamente diferentes com o teste de Tukey, $\mathrm{p}<0,05$.

Resultados a, b, c, d sendo que "a" mostra maior relação de homogeneidade dos resultados e "d" menor relação de homogeneidade. 
Para melhor elucidação dos dados, estes foram submetidos ao teste de Tukey, que serviu para mostrar a homogeneidade entres os valores das médias nos grupos de doses e por datas, representada por (a, b, c, d), onde "a" tem maior relação de homogeneidade e "d" a menor relação de homogeneidade. Avaliando os valores estatísticos das médias, pode ser observado que o grupo de dose com maior relação de homogeneidade entre todos os grupos e datas analisados, foi o de $25 \mathrm{kGy}$, principalmente no $21^{\circ}$ dia.

\subsubsection{Correlação entre as doses de irradiação, tempo e tipos celulares}

$\mathrm{Na}$ TAB. 3 pode-se observar o resultado das análises de variâncias unifatorial (ANOVA) efetuadas nos fatores: localização, radiação e tempo. Ao passo que as análises de variâncias multifatorial (MANOVA) foram efetuadas para as variáveis de localização vs radiação, localização vs tempo, radiação vs tempo, localização vs radiação vs tempo.

Tabela 3 - Correlação entre dose de irradiação do enxerto com os tempos (3ำ, $7^{0}$ e $21^{\circ}$ dias) após enxertia e localização dos queratinócitos, fibroblastos, células de defesa e vasos sanguíneos

\begin{tabular}{ccccc}
\hline Fatores & Queratinócitos & Fibroblastos & $\begin{array}{c}\text { Células } \\
\text { de } \\
\text { Defesa }\end{array}$ & $\begin{array}{c}\text { Vasos } \\
\text { Sanguíneos }\end{array}$ \\
\hline $\begin{array}{c}\text { Localização (extremidade } \\
\text { ou centro) }\end{array}$ & $<0,001$ & 0,968 & 0,109 & 0,190 \\
Radiação & 0,198 & $* 0,094$ & $* 0,054$ & 0,565 \\
Tempo & $<0,001$ & $<0,001$ & $<0,001$ & $<0,001$ \\
\hline Localização vs Radiação & 0,100 & 0,386 & 0,686 & 0,686 \\
\hline Localização vs Tempo & $<0,001$ & 0,030 & 0,004 & 0,004 \\
\hline Radiação vs Tempo & 0,285 & 0,143 & 0,020 & 0,580 \\
\hline Localização vs Radiação & $* 0,051$ & 0,452 & 0,195 & 0,903 \\
\hline vs Tempo & ${ }^{*}$ & 0,050 \\
\hline
\end{tabular}

Valores de $p<0,05$, pelos testes de ANOVA unifatorial e multifatorial MANOVA.

*Valores marginalmente significativos, mostrando tendência por estarem com $p>0,05$ e $p<0,10$.

Verificou-se que a distribuição da contagem dos queratinócitos e o fator tempo apresentaram correlação positiva, altamente significativa $(p<0,001)$, assim como os fatores localização vs tempo $(\mathrm{p}<0,001)$. Os fatotres localização vs radiação vs tempo apresentaram correlação marginal, sinalizando tendência $(p=0,051)$ para o crescimento de queratinócitos. 
Para os fibroblastos foi observada correlação positiva, altamente significativa com o fator tempo $(p<0,001)$, e correlação moderada para localização vs tempo $(\mathrm{p}=0,030)$.

Para as células de defesa, o fator tempo apresenta alta significância de $(p<0,001)$ e o fator radiação sinalizou tendência de $(p=0,054)$, o fator localização vs tempo a correlação foi positiva $(p=0,004)$ e os fatores radiação vs tempo apresentaram significância moderada $(p=0,020)$.

Os vasos sanguíneos apresentaram alta correlação positiva com o fator tempo $(p<0,001)$ e localização vs tempo $(p=0,004)$.

\subsubsection{Distribuição da média das medianas da quantidade de células, divididas nas datas de eutanásia e localização no tecido}

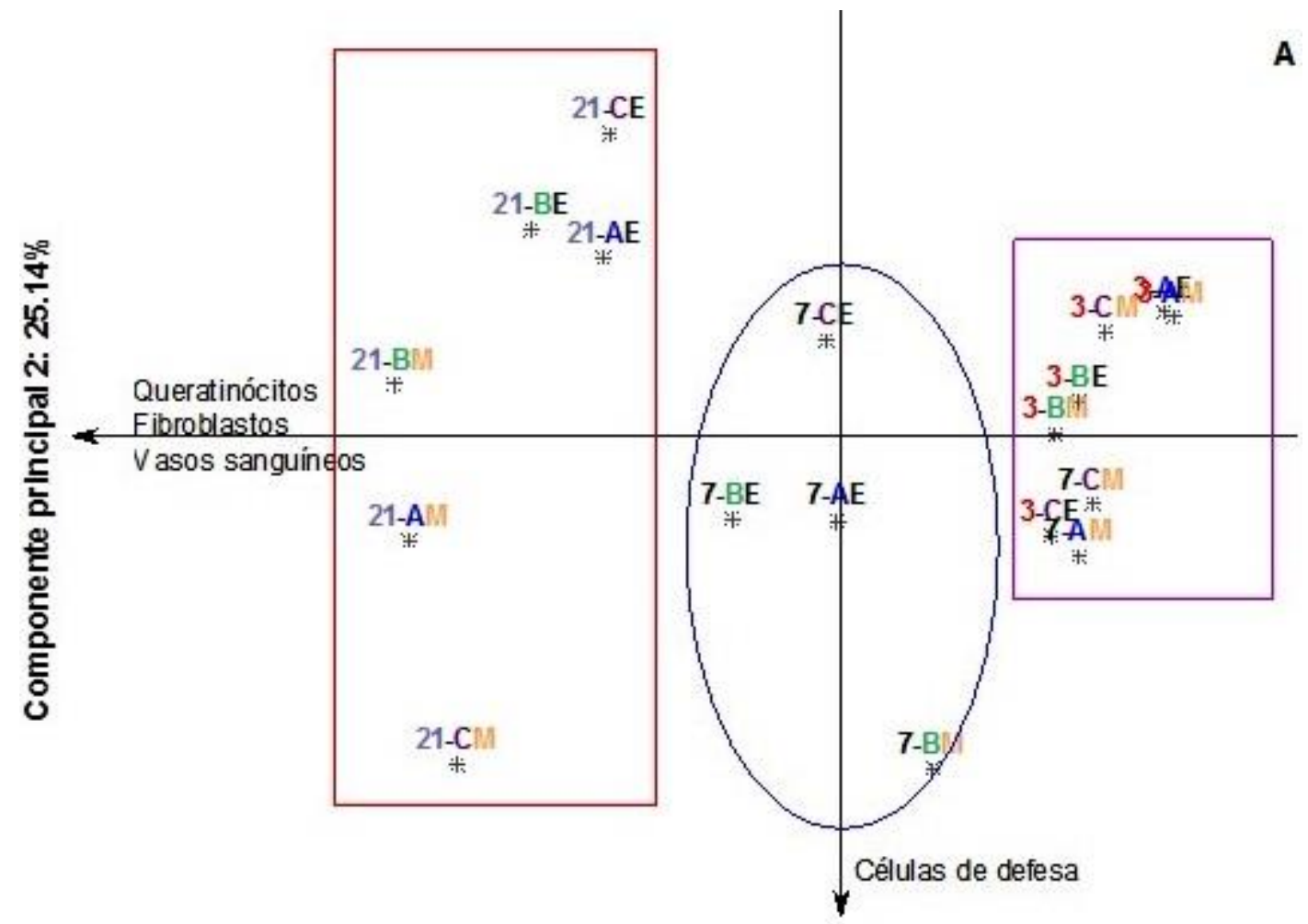

Componente principal 1: $58.09 \%$

Figura 12 - Representação gráfica da distribuição da média das medianas da quantidade de células, divididas nas datas de eutanásia e localização no tecido. Sendo que: 3, 7 e 21 representam as datas; $A$, B e $C$ representam os grupos de doses (não irradiado, 25 kGy e 50 kGy, respectivamente); E e M representam a localização das contagens de células (extremidades e centro do tecido, respectivamente). 
Notam-se três divisões no gráfico da FIG. 12, com as medias das medianas de cada grupo de dose por data de eutanásia com ( $\mathrm{n}=4$ animais). Onde, quanto mais distante do eixo $\mathrm{X}$ e mais a esquerda do eixo $\mathrm{Y}$, maior é a quantidade de células, desta forma podemos notar que células de defesa tiveram maior aumento celular, em um menor tempo; já queratinócitos, fibroblastos e vasos sanguíneos apresentam maior quantidade no número de células ao longo do tempo na reparação tecidual (APENDICE $B, C$ ).

O primeiro retângulo em roxo da direita para a esquerda, contem os dados do terceiro dia, para o grupo (não irradiado - A) como os irradiados a (25 kGy - B) e $(50$ kGy - C), (extremidade do tecido - E) e (centro do tecido - M). No terceiro dia verificou-se pouca dispersão dos dados na fase inicial do crescimento celular. Neste mesmo retângulo notamos a presença de dois pontos do sétimo dia, sendo eles do centro do tecido do grupo não irradiado e irradiado a 50 kGy (7-AM e 7-CM), estes dados, como estão mais a direita do gráfico e mais próximos ao eixo $X$, são aqueles que têm menores quantidades de células por tempo, sendo assim estes dois pontos do sétimo dia apresentaram um menor crescimento comparado com os pontos que estão na elipse em azul, no centro do gráfico.

A elipse em azul no centro do gráfico apresenta quatro pontos, sendo todos do sétimo dia e dos grupos não irradiado e irradiado a 25 kGy e 50 kGy, sendo três deles da extremidade e um do centro do tecido. Este ponto (7-BM), que é o dado de sétimo dia irradiado a 25 kGy e centro do tecido, esta mais a direita do gráfico e mais distante dos outros pontos, pelo seu posicionamento, podemos notar que os outros três dados já apresentam uma maior quantidade de células por estarem mais a esquerda, entre os eixos $\mathrm{X}$ e $\mathrm{Y}$.

Entretanto, o retângulo em vermelho a esquerda do gráfico contêm em sua totalidade os pontos do vigésimo primeiro dia dos três grupos de doses e das duas variáveis de localização. Estes dados apresentam as maiores quantidades de células por estarem mais a esquerda do gráfico. Ainda podemos ver uma divisão na parte mais superior do retângulo vermelho, onde todos os três pontos são referentes à extremidade do tecido, e o ponto com maior quantidade de células é o 21-BE, já na região mais a esquerda referente aos grupos do centro do tecido, nota-se que o ponto com maior quantidade de células é o 21-BM, junto com o ponto 21-AM. Os tecidos 21-BM e 21-BE apresentam uma maior produção de células no tecido. 
5.2 Expressão do colágeno tipo I humano e do colágeno dos tipos I e III de camundongo após enxerto de pele irradiada e não irradiada

Na FIG. 13 pode-se observar a expressão do colágeno tipo I humano (FIG. $13 \mathrm{~A}-\mathrm{C}$ ) com $\mathrm{n}=3$ animais, colágeno do tipo III de camundongo (FIG. 13 D-F) com $\mathrm{n}=3$ animais e colágeno do tipo I de camundongo (FIG. $13 \mathrm{G}-\mathrm{I}$ ) com $\mathrm{n}=4$ animais, por imunofluorescência em enxerto de pele humana não irradiada e irradiada a 25 kGy e 50 kGy em camundongos Nude, submetidos a eutanásia no $21^{\circ}$ dia após enxertia. Foi confirmada a eficiência dos anticorpos utilizando pele humana não enxertada e pele integrada de camundongo Nude, tanto para os controles positivos, quanto para os controles negativos (APÊNDICE D).
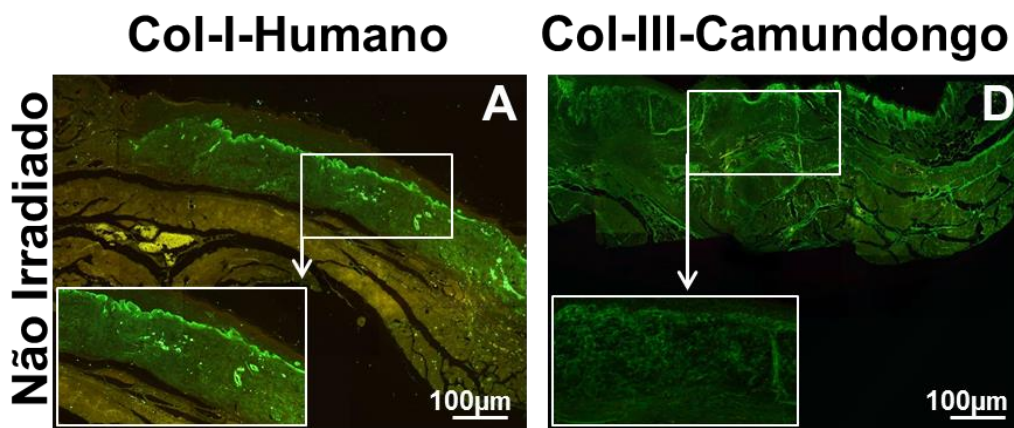

Col-I-Camundongo
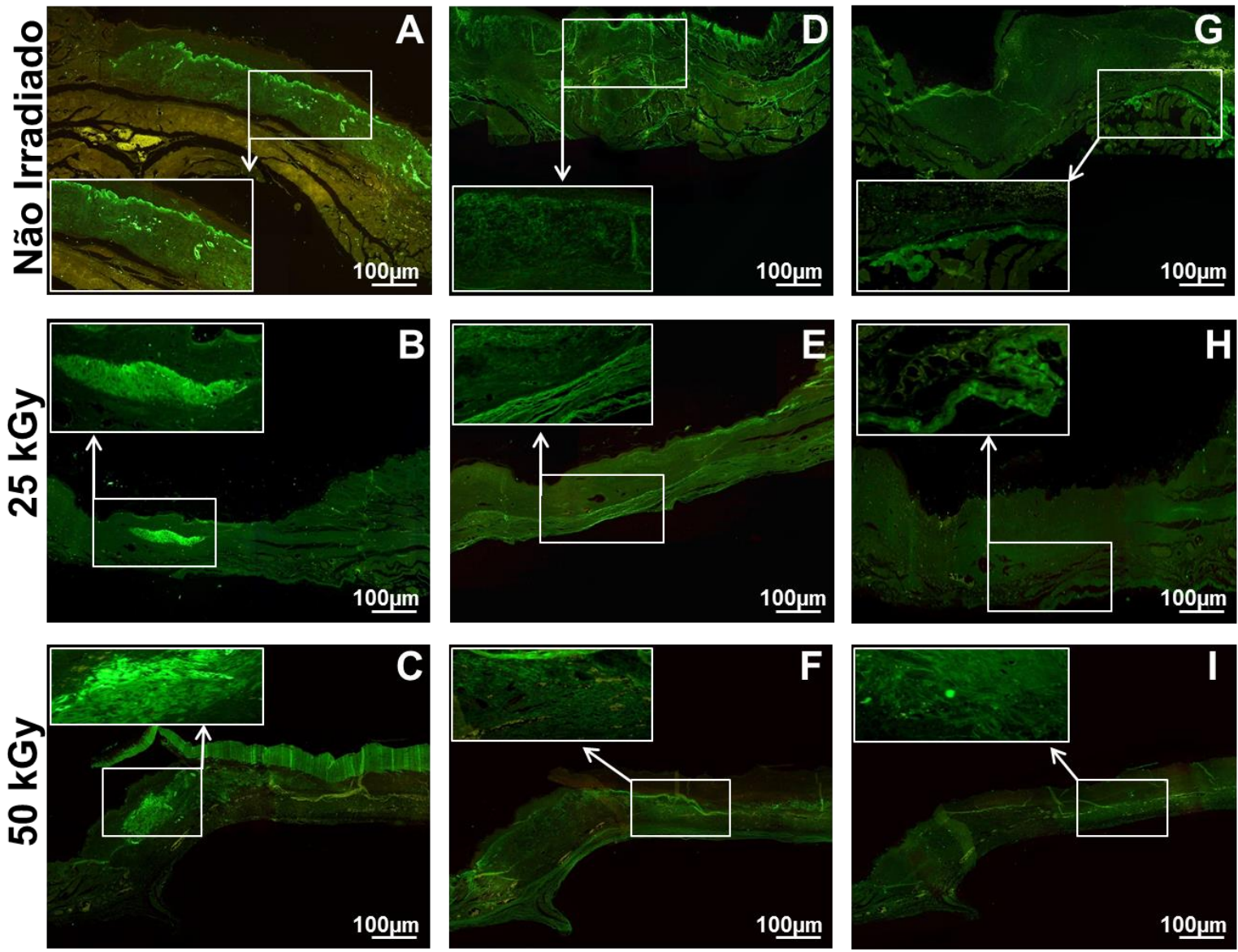

Figura 13 - Detecção de colágeno, por imunofluorescência, (verde fluorescente) em cortes transversais da pele de camundongos Nude, eutanásiados no $21^{\circ}$ dia após enxertia. A, B e C) colágeno do tipo I humano; D, E e F) colágeno do tipo III de camundongo; $\mathrm{G}, \mathrm{H}$ e I) colágeno do tipo I de camundongo; $A$, D e G) não irradiada irradiadas; B, E e H) 25 kGy; e C, F e I) 50 kGy. Aumento de 100X. Quadros aumento de 200X. 
O grupo com tecido não irradiado apresenta maior expressão de colágeno tipo I humano agregado ao tecido animal, por todo o tecido, mas com predominância nas extremidades (FIG. 13 A). Identificamos em maior aumento (200x) a intensa expressão do colágeno tipo I humano nesta região do tecido (FIG. $13 \mathrm{~A}$ - Detalhe em maior aumento) em relação aos grupos irradiados (FIG. 13 B-C). O grupo com a pele irradiada a 25 kGy apresenta uma tênue expressão de colágeno tipo I humano, distribuído nas extremidades do tecido (FIG. 13 B - Detalhe em maior aumento). No que se refere ao grupo com a pele irradiada a 50 kGy (FIG. 13 C - Detalhe em maior aumento), observamos um padrão de distribuição do colágeno tipo I humano similar ao grupo da pele irradiada a 25 kGy. (APÊNDICE E, F, G).

Para o colágeno tipo III de camundongo (FIG. 13 D-F), o grupo com enxertia de pele não irradiada apresentou menor expressão de colágeno. Já o grupo irradiado a $25 \mathrm{kGy}$ apresenta maior intensidade na fluorescência para o colágeno tipo III de camundongo (FIG. 13 E) em relação ao grupo não irradiado (FIG. $13 \mathrm{D}$ ). Observamos que o tecido irradiado a $50 \mathrm{kGy}(\mathrm{FIG} .13 \mathrm{~F}$ ) tem o mesmo padrão de marcação do grupo de 25 kGy (FIG. 13 E) (APÊNDICE E, F, G).

Para os tecidos marcados por imunofluorescência com o colágeno do tipo I de camundongo (FIG. $13 \mathrm{G}-\mathrm{I}$ ), apesar da pouca expressão, todos os grupos mostram o mesmo padrão de marcação. Esta expressão foi mais marcante na região da derme profunda, demostrando padrão similar entre os tecidos irradiados e não irradiado (APÊNDICE E, F, G). 


\subsubsection{Quantificação da distribuição do colágeno tipo I humano na área de reparação tecidual}

Para verificar a quantidade da expressão de colágeno I humano (FIG. 14) foi realizada a análise de variâncias unifatorial (ANOVA), e seus resultados distribuídos em gráficos separados em extremidades $(A)$, centro $(B)$ e extremidade e centro (C) este ultimo representando a área total do tecido. Representados em porcentagem (\%) da área total.

A

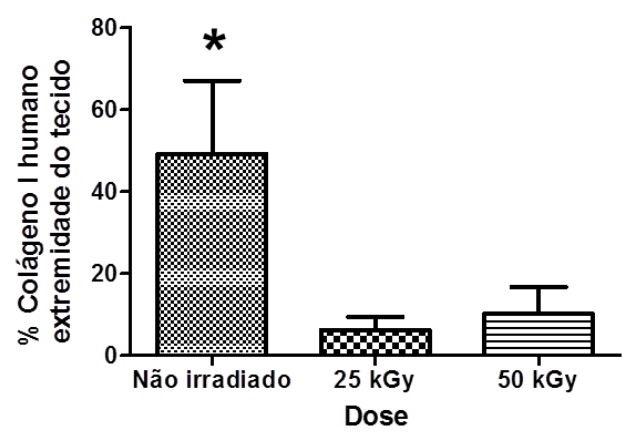

B

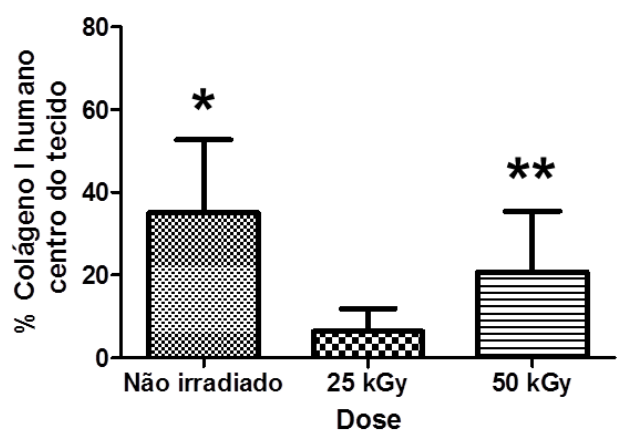

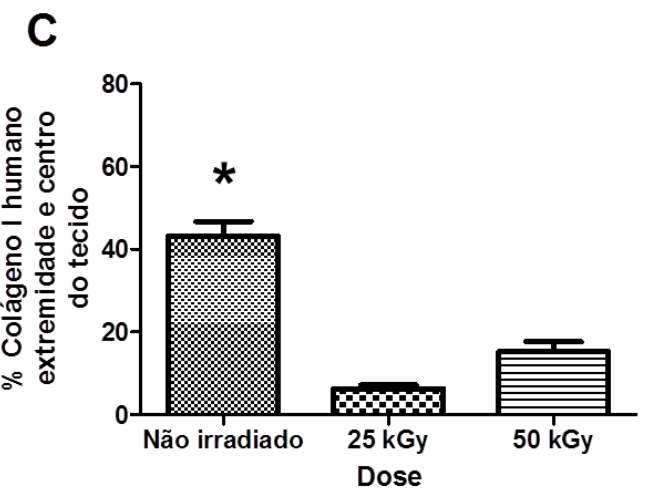

Figura 14 - Gráficos da quantidade de colágeno tipo I humano no tecido de camundongos Nude, eutanasiados no $21^{\circ}$ dia, segundo sua localização e dose de irradiação. A) extremidade do tecido, B) centro do tecido, C) extremidade e centro do tecido. Comparação entre grupos teste de Tukey, onde $\left(^{*}\right)$ mostram correlação positiva altamente significativa, $\left.{ }^{(* *}\right)$ o grau de correlação de significância moderada.

Na FIG. 14 A, os dados em porcentagem na região das extremidades dos tecidos, mostraram que o grupo não irradiado tem maior significância $(p<0,0001)$, em relação aos grupos irradiados. Na região do centro dos enxertos (FIG. 14 B) a quantidade de colágeno I humano no grupo não irradiado tem maior significância 
( $p<0,0001)$, em relação ao grupo irradiado a 25 kGy já o grupo de 50 kGy apresentou significância moderada.

Quando considerada a área total do enxerto (FIG. 14 C), a porcentagem de colágeno tipo I humano no grupo não irradiado (43,20\%) mostrou ser mais significativa $(p<0,0001)$ em relação aos grupos irradiados com 25 e 50 kGy (6,30\% e 15,25\%, respectivamente).

Portanto, a quantificação do colágeno tipo I humano por análise de imagem demonstrou maior quantidade destas fibras no tecido não irradiado, em todas as regiões estudadas: extremidades, centro e extremidade e centro (FIG. 14 A-C).

\subsubsection{Quantificação da distribuição do colágeno tipo III de camundongo na área de reparação tecidual}

Os gráficos da quantificação de colágeno tipo III de camundongo seguiu o mesmo padrão utilizado para o colágeno tipo I humano (item 5.2.1)

A

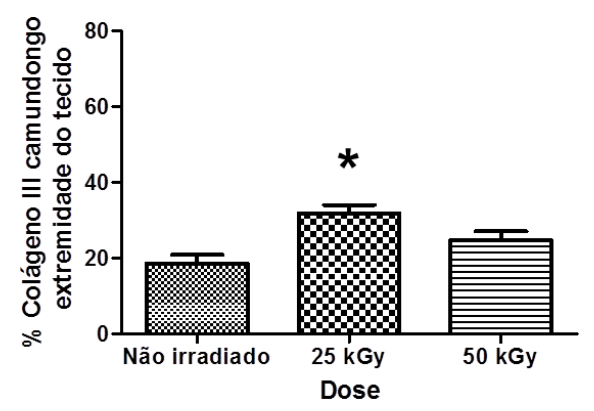

C
B

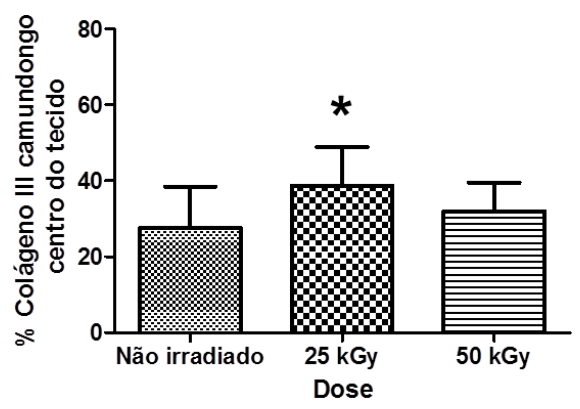

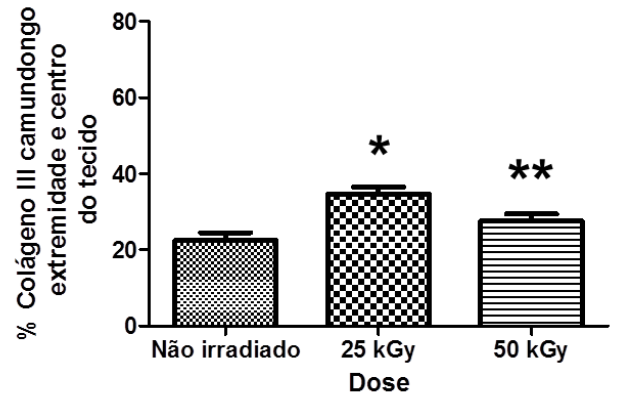

Figura 15 - Gráficos da quantidade de colágeno tipo III de camundongo no tecido de camundongos Nude, eutanasiados no $21^{\circ}$ dia, segundo sua localização e dose de irradiação. A) extremidade do tecido, B) centro do tecido, C) extremidade e centro do tecido. Comparação entre grupos teste de Tukey, onde $\left({ }^{*}\right)$ mostram correlação positiva altamente significativa, $\left({ }^{* *}\right)$ o grau de correlação de significância moderada. 
Foi realizada a analise de variâncias unifatorial (ANOVA) para verificar a quantidade da expressão de colágeno III camundongo (FIG. 15), sendo que os resultados apresentaram diferentes graus de correlação e significância de $p=0,0009, p=0,0270$ e $p<0,0001$, para extremidade (FIG. $15 \mathrm{~A}$ ), centro (FIG. $15 \mathrm{~B}$ ) e extremidade e centro do tecido (FIG. $15 \mathrm{C}$ ), respectivamente.

Na FIG. 15 A, os dados em porcentagem das extremidades do tecido, para o teste de Tukey, demonstram que o grupo irradiado a 25 kGy possui correlação positiva em comparação com o grupo não irradiado e o grupo de 50 kGy.

Para os tecidos quantificados no centro do tecido (FIG. 15 B), a comparação pelo teste de Tukey demonstrou que a diferença de correlação foi entre os grupos de 25 kGy e os grupos não irradiado e 50 kGy. O resultado de ANOVA apresenta correlação positiva moderada, da quantidade de colágeno III.

Para os tecidos da extremidade e centro (FIG. $15 \mathrm{C}$ ), segundo o teste de Tukey, o grupo o de 25 kGy (34,60\%) tem maior correlação positiva comparada com não irradiado (22,48\%), já o grupo irradiado a 50 kGy $(27,63 \%)$ apresenta significância moderada.

Desta forma, o colágeno tipo III de camundongo apresentou maior quantidade de fibras de colágeno no tecido irradiado a $25 \mathrm{kGy}$, em todas as regiões estudadas: extremidades, centro e extremidade e centro (FIG. 15 A-C). 


\subsubsection{Quantificação da distribuição do colágeno tipo I de camundongo na área de reparação tecidual}

A

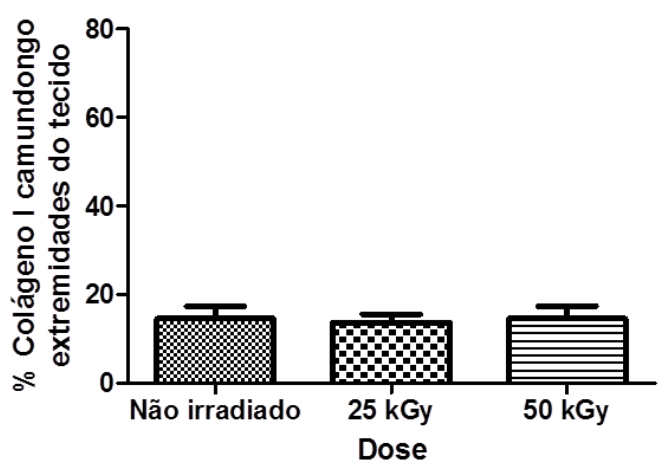

C
B

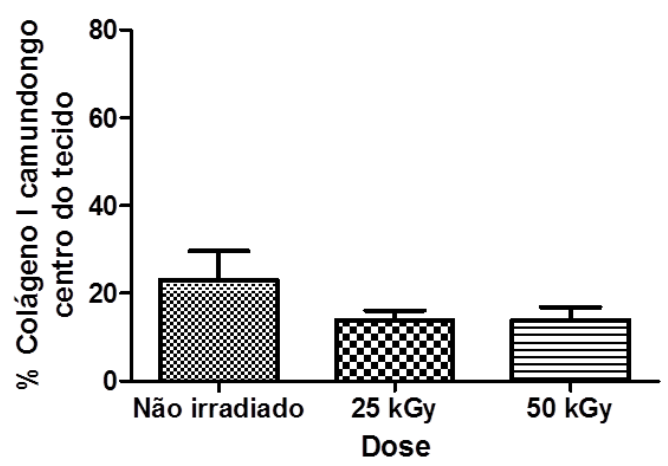

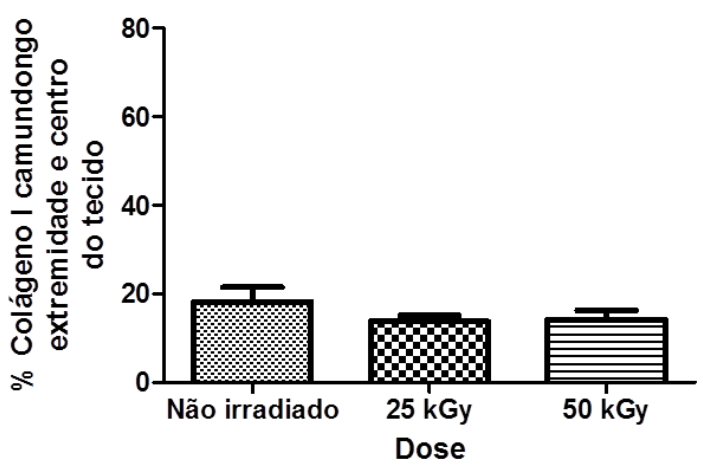

Figura 16 - Gráficos da quantidade de colágeno tipo I de camundongo no tecido de camundongos Nude, eutanasiados no $21^{\circ}$ dia, segundo sua localização e dose de irradiação. A) extremidade do tecido, B) centro do tecido, C) extremidade e centro do tecido.

Para verificar a quantidade da expressão de colágeno I camundongo (FIG. 16) foi realizado a analise de variâncias unifatorial (ANOVA), sendo que os resultados apresentaram diferentes graus de correlação, porém não exibindo nenhum resultado significante $(p=0,9578, \quad p=0,2517$ e $p=0,3495)$, para extremidade (FIG. $16 \mathrm{~A}$ ), centro (FIG. $16 \mathrm{~B}$ ) e extremidade e centro do tecido (FIG. 16 C), respectivamente.

Os dados utilizados para o teste de Tukey (FIG. 16 A, B e C), apresentaram uma homogeneidade entre todos os grupos não irradiado, e irradiados a 25 e 50 kGy $(18,21 \%, 13,78 \%$ e $14,26 \%$, respectivamente), sendo assim pode-se confirmar que não há diferença significativa entre os grupos. 


\subsection{Analise da influencia do tecido irradiado na regeneração do tecido animal}

Podemos visualizar na FIG. 17, as áreas de cicatrização, coradas com HE, de camundongos eutanasiados no $21^{\circ}$ dia, dos grupos com pele humana não irradiada, irradiada a 25 e 50 kGy. Imagens representativas da remodelação observada em 4 animais de cada grupo.

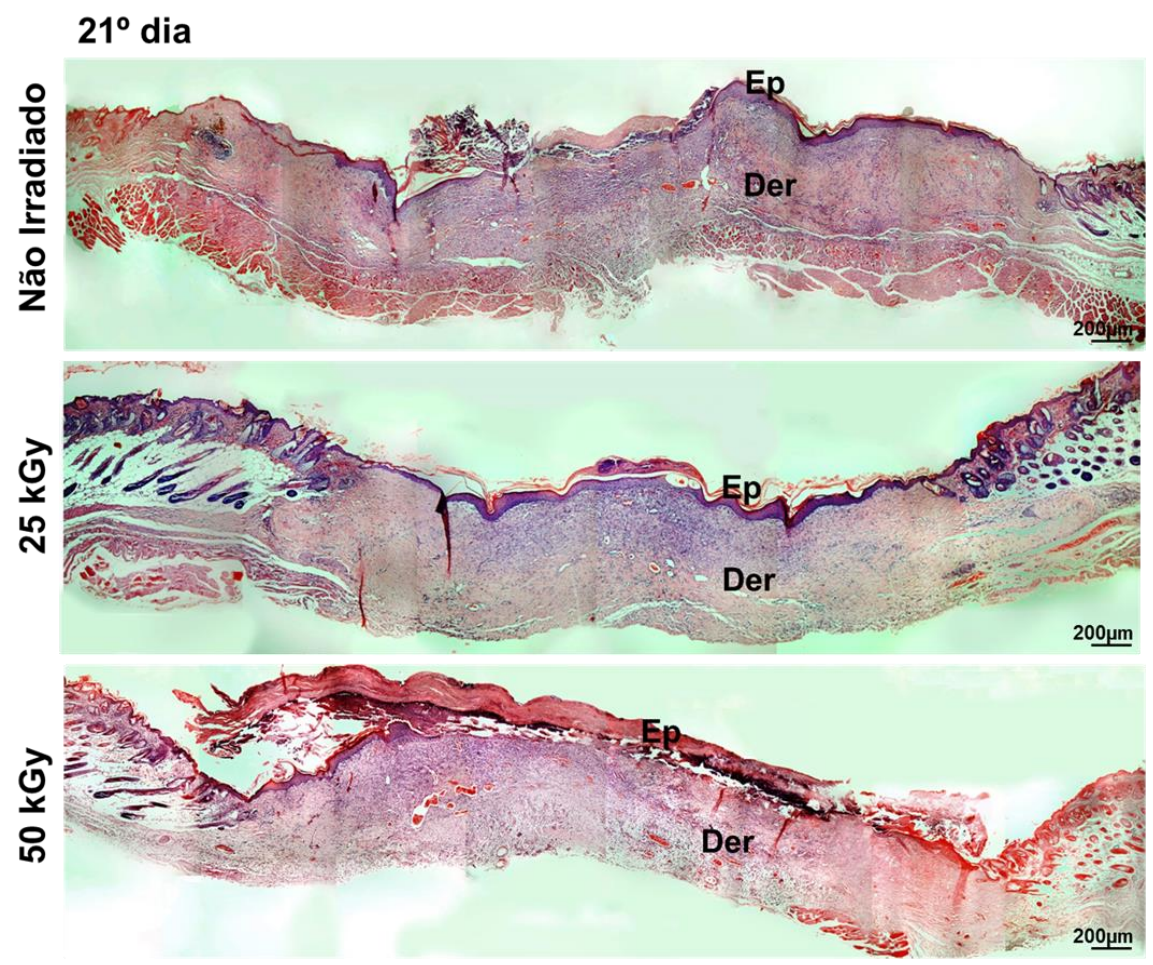

Figura 17 - Histologia das amostras, coradas com HE, em cortes transversais, evidenciando o remodelamento da pele de camundongos Nude, submetidos a enxertia de pele humana, com tecidos não irradiado, irradiadas a $25 \mathrm{kGy}$ e 50 kGy, eutanásiados no 21ํ dia após enxertia. Representada a epiderme por (Ep) e por (Der) a região da derme em reparação. Todas as imagens estão em um aumento de $100 \mathrm{X}$

Observamos que as áreas onde foram utilizados os tecidos humanos não irradiados apresentaram a derme ainda em estágio de remodelação e os tecidos irradiados a 25 kGy apresenta a derme remodelada, como também visto no grupo de 50 kGy.

Em relação à epiderme, não ocorreu o fechamento de queratinócitos nas áreas onde foram utilizados tecidos humanos não irradiados como também no tecido irradiado a $50 \mathrm{kGy}$, diferente do tecido irradiado a $25 \mathrm{kGy}$, onde pode-se observar a epiderme totalmente recomposta ao longo da área de cicatrização. 


\section{DISCUSSÃO}

A pele humana retirada de doadores multi-orgãos tem provado ser um material muito eficaz, para cobertura de feridas como queimaduras profundas e de grandes extensões, quando quantidades de autoenxertos não estão disponíveis para estes tratamentos os aloenxertos tornam-se indispensáveis. O tratamento com aloenxertos apresenta propriedades únicas para a cobertura temporária, fornecendo condições favoráveis para a re-epitelização do local enxertado (Singh et al., 2016).

Segundo Wurzer et al. (2016), em seu estudo com 11 especialistas de 36 países, mostrou que os aloenxertos são os mais utilizados (51\%), dentre os tipos de materiais empregados para fechamentos de queimaduras, como cobertura temporária na clinica diária.

Porém após sete a nove dias, quando da retirada desta cobertura, é normal que o cirurgião observe a incorporação da derme alógena ao leito em reparação, propiciando um melhor leito para uma segunda intervenção com pele autógena ou células cultivadas (Bolgiani \& Serra, 2010). Este fato é observado com maior frequência quando a pele alógena foi previamente esterilizada por radiação ionizante (comunicação verbal), porém até o momento este fenômeno não foi pesquisado cientificamente.

Já Shanmugam et al. (2015) em seus estudos utilizaram xenoenxertos em camundongos atímicos, observando que o modelo de ferida neste tipo de animal é muito semelhante aos observados em uma ferida aguda humana e que este modelo é de grande valia para estudar as interações complexas que ocorrem durante a fase de cicatrização de ferida como a de humanos.

O presente estudo visou estabelecer se o enxerto de pele humana radioesterilizada é capaz de remodelar mais rapidamente e com melhor qualidade a área do tecido lesionado, em modelo animal de camundongo NUDE. Em trabalho anterior do mesmo grupo, pode-se observar uma aceleração no processo de reparação, quando foram utilizados enxertos irradiados com $25 \mathrm{kGy}$, sem alterações biomecânicas na organização final do tecido, após 90 dias (Bringel, 
2011). Como continuidade deste estudo e com o objetivo de entender melhor este processo, focamos nas análises histológicas direcionadas à quantidade e distribuição das células e vasos sanguíneos presentes na área de cicatrização, assim como o processo de remodelamento do tecido, observando a marcação com anticorpos específicos para determinar o tipo (I ou III) e origem (camundongo ou humano) do colágeno presente.

Levando em consideração que os principais tipos celulares envolvidos na remodelação da cicatrização, são primeiramente os fibroblastos, células de defesa e posteriormente o aparecimento de queratinócitos e vasos sanguíneos, estes foram quantificados ao longo do tempo $\left(3^{\circ}, 7^{\circ}\right.$ e $21^{\circ}$ dias) e verificada a influência do enxerto não irradiado e irradiado nas doses de 25 e 50 kGy (FIG. 11 e TAB. 2 e 3).

Desta forma foi observado que no $3^{\circ}$ dia ocorreu maior migração celular na região em cicatrização dos camundongos que receberam enxertos irradiados. No $7^{\circ}$ dia foram encontrados vasos sanguíneos e infiltrado celular, também apresentou o crescimento de queratinócitos somente nas extremidades do tecido dos animais que receberam enxertos irradiados e não irradiados. No $21^{\circ}$ dia temos uma distribuição mais homogênea (TAB. 2) das células nos tecidos em reparação que receberam enxertos irradiados com 25 kGy, podendo se afirmar que os animais que receberam estes enxertos apresentam melhor estruturação da cicatrização.

No estudo estatístico individual e comparativo, levando em consideração o tempo de cicatrização, radiação e localização (TAB. 3 e APENDICE. B). O fator tempo apresentou elevada significância estatística com todos os grupos de células ( $p<0,001)$, o que denota maior efeito sobre a cicatrização, como esperado, assim como o efeito da localização vs tempo apresentou correlação forte e moderada com todas as variáveis.

$\mathrm{Na}$ TAB. 3 o fator radiação no teste de ANOVA para fibroblastos e células de defesa apresenta sinalização de tendência no crescimento celular, o mesmo foi apresentado em MANOVA em localização vs radiação vs tempo para queratinócitos, não apresentando significância estatística $(p<0,05)$ entre os três grupos analisados. Já em MANOVA o fator radiação vs tempo teve correlação moderada $(p=0,020)$ para células de defesa. 
A provável explicação para a sinalização do aumento da proliferação celular, pode ser devido a radiação utilizada de 25 e 50 kGy ter iniciado uma desestruturação da malha de colágeno, permitindo que fibroblastos e células de defesa migrem mais facilmente para 0 enxerto e consequentemente proporcionando melhor leito para a migração dos queratinócitos.

Uma observação feita, durante as análises dos tecidos corados com HE, foi a do crescimento dos queratinócitos que ocorreu das extremidades para o centro do tecido, iniciando abaixo do enxerto e adentrando ao meio do mesmo, subindo para a região entre a derme e a epiderme, sendo observado o crescimento a partir do $7^{\circ}$ dia após feita a enxertia no camundongo, como visto na TAB. 2.

O fator localização vs radiação vs tempo (TAB. 3) em MANOVA, em relação aos queratinócitos apresenta tendência $(p=0,051)$ no crescimento destas células, sendo que a produção destas aumenta proporcionalmente ao longo do tempo.

O fator radiação vs tempo mostra significância moderada $(p=0,020)$ no crescimento de células de defesa, isto pode ser devido ao estimulo que os camundongos tiveram por ter sido submetido à enxertia, o que desencadeou uma resposta inflamatória no animal. Na literatura é dito por Momtazi et al. (2012) e Charles River (2009) que, quando estimulado, o camundongo Nude produz linfócitos B. Também pode ser observado na TAB. 2, que as células de defesa tiveram maior aumento em menor tempo, em relação aos outros grupos celulares.

Nas analises estatísticas (TAB. 3), os vasos sanguíneos apresentaram alta correlação positiva com o fator tempo $(p<0,001)$, em ANOVA, e localização vs tempo, em MANOVA também apresenta correlação positiva $(p=0,004)$. Indicando o aumento da vascularização na área em cicatrização.

Este crescimento dos vasos sanguíneos está intimamente ligado ao processo de deposição da matriz extracelular, devido ao aumento de fibroblastos e à produção de colágeno, sendo denominado de fibroplasia, para sua eficiência é necessário que ocorra em paralelo a formação de vasos sanguíneos, ou seja, a neovascularização da região (Knighton et al., 1981)

No APENDICE. B, que correlaciona linearmente às doses de radiação na pele enxertada e o tempo, em relação aos parâmetros da área em regeneração, pode-se observar que quando o valor de uma das variáveis "células" aumenta em media o valor das outras variáveis aumenta de forma proporcional, desta forma 
podemos inferir que o aumento de um determinado grupo de célula implica no aumento de outros grupos celulares.

$\mathrm{Na}$ TAB. 2 notamos que no $21^{\circ}$ dia os tecidos irradiados a $25 \mathrm{kGy}$ apresentaram maior homogeneidade de resultados, em relação aos outros grupos de doses, no crescimento no centro e extremidades do tecido 21-extremidade e 21-centro, estes pontos estão ligeiramente mais a frente dos outros pontos, quando analisados individualmente (FIG. 12 e APÊNDICE C).

Contudo, com os experimentos elaborados, não foi possível determinar se houve ou não a incorporação do enxerto humano e de como estava a remodelação das fibras de colágeno do animal, no processo de reparação tecidual.

Segundo Bourroul (2004), em suas analises de fotomicrográfias de pele para aloenxerto, coradas com tricromo de Mallory, os cortes histológicos apresentam uma progressiva alteração, dose dependente, na intensidade da coloração azul que identifica o colágeno na derme. As amostras irradiadas com dose de 50 kGy apresentam a derme com um tom azul menos intenso do que as amostras irradiadas com dose de $25 \mathrm{kGy}$, desta forma podemos dizer que ocorre uma maior desestruturação nas fibras colágenas irradiadas a 50 kGy e uma maior desorganização destas fibras.

A desestruturação da derme irradiada, como descrito na dissertação de Bourroul (2004), também foi observada nos tecidos corados com HE do presente estudo (FIG. 11 e APÊNDICE A), visualizando as fibras colágenas mais esparsas. Esta alteração auxiliou as células do receptor (camundongo) a migrarem para estes espaços, fazendo com que a reparação do tecido ocorra de forma mais rápida do que no tecido não irradiado.

Segundo Bringel (2011), a região do enxerto nos camundongos Nude foi submetida a analise macroscópica, imagens de tomografia de coerência óptica e ensaios biomecânicos, com o que foi possível concluir que os enxertos irradiados a 25 kGy promoveram uma contração inicial maior, mas essa alteração não interferiu na dimensão da área final de reparação, ainda, os animais que receberam esses enxertos apresentaram mais rápido fechamento da ferida em comparação com os demais.

Gawronska-Kozak et al. (2006) mostraram, em seus experimentos feitos em camundongos Nude, que a aparência da área lesionada é semelhante a da 
área não lesionada. A organização espacial das fibrilas de colágeno da derme difere entre a pele intacta e a pele em processo de reparação em outros modelos animais, ou seja, a pele não lesionada é composta por fibrilas de colágeno paralelas, longas e regulares, enquanto que na pele onde ocorre a formação de cicatriz, as fibrilas são curtas e desorganizadas.

Levando-se em consideração os dados obtidos e os resultados encontrados na literatura, pode-se entender a importância do estudo comparativo das regiões de cicatrização, observadas no camundongo Nude, com relação à presença do colágeno tipo I humano remanescente do enxerto e do colágeno tipo I e III de camundongo, produzidos durante o processo de reparação.

No presente estudo, o grupo que recebeu o tecido não irradiado, apresenta expressão de colágeno tipo I humano agregado ao tecido animal (FIG. 13 A), com grande expressão deste colágeno nas extremidades e no centro do tecido (APÊNDICE E). Identificamos quantitativamente pela FIG. 14 a intensa expressão $(43,20 \%)$ nesta região do tecido. Apresentando ainda menor expressão do colágeno do tipo III de camundongo $(22,48 \%)$ comparado com os outros dois grupos irradiados (FIG. 15), e sim como do colágeno do tipo I de camundongo $(18,21 \%)$, porém neste caso, não apresentando significância estatística em relação aos grupos irradiados (FIG. 16), vemos que isto levou a menor contração do tecido (ANEXO A), com uma cicatrização mais lenta e atraso no remodelamento tecidual (FIG. 17).

O grupo que recebeu tecido de pele irradiada a 25 kGy apresenta um encapsulamento do colágeno tipo I humano (FIG. 13 B), com uma porcentagem de 6,30\%, porém com maior expressão nas extremidades e menor expressão no centro do tecido (APÊNDICE F), mas teve maior expressão do colágeno do tipo III de camundongo (34,60\%) entre os três grupos, na região de reparação (FIG. 15) e pouca expressão de colágeno do tipo I de camundongo (13.78\%) (FIG. 16). Notamos que este tecido apresentou maior contração da área em cicatrização (ANEXO A), e em sua grande maioria teve fechamento quase que completo de queratinócitos, e com remodelamento da derme mais completa comparado com outros grupos de tecidos (FIG. 17).

No que se refere ao grupo de animais que receberam os enxertos de pele irradiada a 50 kGy observamos um padrão de distribuição do colágeno tipo I humano (FIG. $13 \mathrm{C}$ ) similar ao grupo da pele irradiada a $25 \mathrm{kGy}$, mas com maior 
área de expressão de imunomarcação (15,25\%) (FIG. 14). A marcação de colágeno do tipo III de camundongo apresentou expressão $(27,63 \%)$ similar ao grupo de 25 kGy (FIG. 13 F e $15 \mathrm{C}$ ), e baixa expressão de colágeno I de camundongo (14,26\%), não apresentando significância estatística (FIG. 16), mas teve menor contração da ferida comparando com o grupo de 25 kGy e maior contração comparada com o grupo não irradiado (ANEXO A), apresentando a epiderme não totalmente formada e a remodelação da derme quase que total (FIG. 17).

Após ser feita a pesquisa bibliográfica, foram encontrados poucos artigos onde os pesquisadores tenham submetido o colágeno do tecido humano enxertado a imunomarcação, para averiguar se houve a inclusão deste na reparação da cicatriz do animal. No presente estudo foi feita a marcação do colágeno I humano e foi observado que ocorreu a integração de parte do tecido enxertado durante o processo de cicatrização.

Segundo Rossio-Pasquier et al. (1999), por volta do $11^{\circ}$ dia, era possível notar, por imunofluorescência, a presença de colágeno tipo I humano na região dérmica da área de cicatrização. No período de 3 a 6 semanas havia intensa remodelação tecidual e as feridas estavam reepitelizadas. Com oito semanas após a injúria, o tecido de granulação ainda permanecia na região da derme animal.

No presente trabalho, também foi observada a presença do colágeno do tipo I de camundongo na derme abaixo do tecido de granulação nos três grupos estudados (FIG. 13 G, H e I), levando a inferir que a remodelação nestes três grupos ainda está em processo, pois praticamente não se encontra colágeno tipo I distribuído ao longo da região dérmica, como na pele íntegra (APÊNDICE D).

Quando comparamos as expressões de colágeno do tipo III (FIG. 15) versos colágeno do tipo I (FIG. 16) do camundongo nos grupos não irradiados e irradiados, podemos observar que no grupo não irradiado temos praticamente a mesma porcentagem $22 \%$ e $18 \%$, respectivamente de ambos os tipos de colágeno, já para os grupos irradiados, pode-se observar que houve uma maior produção de colágeno do tipo III do que colágeno do tipo I, sendo 35\% e 14\% para o grupo irradiado a 25 kGy, e $28 \%$ e 14\% para o grupo irradiado a 50 kGy. Esta maior produção de colágeno do tipo III pode ter levado a uma melhor remodelação da derme nos grupos irradiados (FIG. 17). 
Nas amostras do $21^{\circ}$ dia (FIG. 17) observamos, nos animais que receberam enxertos irradiados a 25 kGy, o fechamento da epiderme, pelos queratinócitos, no meio do tecido ocorrendo a junção destas células, diferente dos tecidos irradiados a 50 kGy e não irradiados que não tiveram o fechamento completo da epiderme, mas com a migração de queratinócitos para no meio do tecido em reparação.

Segundo Lofeego-Filho et al. (2006) de acordo com a fisiologia dos enxertos, cronologicamente a primeira complicação esperada seria a não integração, e a segunda, mais temida, contração excessiva com distorção tecidual.

De acordo com Aarabi et al. (2007) os camundongos contraem a sua musculatura em resposta a lesão tecidual, isso cria varias confusões ao usar modelos de camundongos murinos, para a cicatrização de feridas, porque há uma diminuição inicial rápida na superfície ferida e após o ferimento, que é puramente relacionado à sua contração tecidual da área lesada, em vez de reepitelização. Levando a mais um desafio para traduzir observações em modelos murinos para o ambiente da ferida humana.

Nas fotos dos animais feitas antes da eutanásia no $21^{\circ}$ dia (ANEXO A) nota-se que há uma diferença visual na remodelação da área de cicatrização nos grupos irradiados principalmente no grupo de $25 \mathrm{kGy}$, o qual aparece com a reparação mais avançada do que no grupo de 50 kGy e não irradiado (Bringel, 2011). Esta singularidade pode ser também visualizada nos cortes histológicos correspondentes (FIG. 17). 


\section{CONCLUSÃO}

- Podemos afirmar que a irradiação na pele humana, quando enxertada, influencia o aumento do número de células no local de cicatrização ao longo do tempo, principalmente na dose de $25 \mathrm{kGy}$, além de proporcionar uma melhor dispersão destas células.

- Foi encontrado colágeno do tipo I humano no local de remodelação, tanto com o uso de enxertos de peles humanas não irradiadas, quanto das irradiadas, analisadas no $21^{\circ}$ dia, indicando incorporação parcial do enxerto ao tecido animal.

- No tecido não irradiado foram encontradas quantidades de colágeno de camundongo tipos I e III praticamente iguais, com uma tendência de expressão maior de colágeno do tipo III. Já nos grupos irradiados o colágeno do tipo III foi mais expresso que o do tipo I, sendo que este último se encontra mais distribuído na região mais profunda da derme.

- O animal que recebeu a pele humana irradiada a $25 \mathrm{kGy}$ apresentou uma cicatrização mais rápida, com melhor remodelamento da derme e fechamento total da epiderme

- Com o resultado das análises pode-se concluir que inicialmente a pele enxertada serviu como arcabouço para proliferação celular e formação de vasos, posteriormente havendo incorporação parcial da mesma auxiliando na reparação tecidual. Sendo que essas respostas foram mais evidentes quando utilizadas as peles humanas irradiadas a $25 \mathrm{kGy}$. 


\section{APÊNDICES}

Apêndice A - Tecidos dos dos controles corados com HE, pele humana não irradiada, irradiada a 25 e 50 kGy e pele de camundongo Nude

- Controle dos tecidos corados em HE

- Pele humana

Não Irradiado

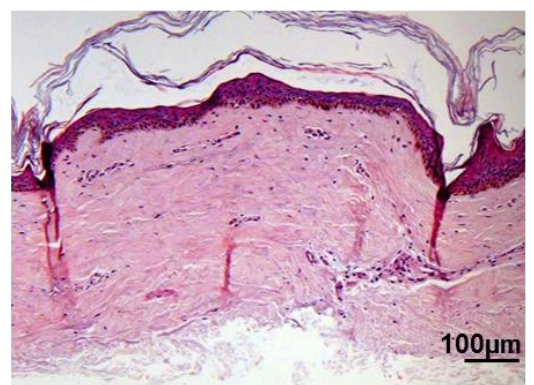

$25 \mathrm{kGy}$

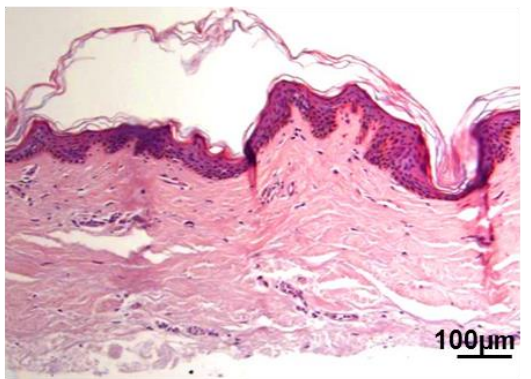

50 kGy

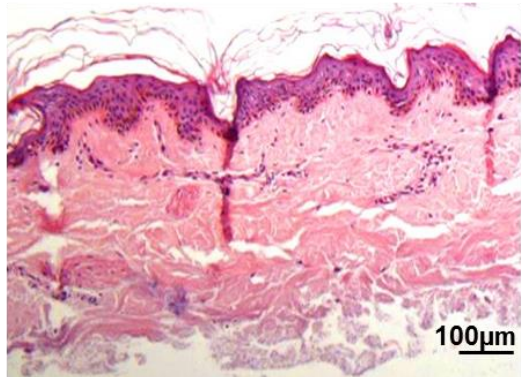

- Pele de camundongo Nude

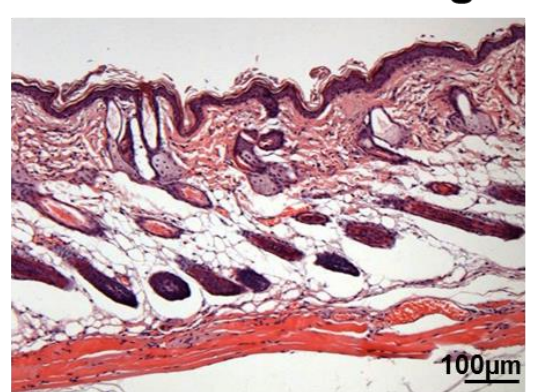


Apêndice B - Matriz de correlação linear entre dose de radiação e tempo de análise com os parâmetros de cicatrização

\begin{tabular}{|c|c|c|c|c|c|c|}
\hline Variáveis & Radiação & Tempo & Queratinócitos & Fibroblastos & $\begin{array}{c}\text { Células } \\
\text { de } \\
\text { Defesa }\end{array}$ & $\begin{array}{c}\text { Vasos } \\
\text { Sanguíneos }\end{array}$ \\
\hline \multirow[t]{2}{*}{ Radiação } & 1 & & & & & \\
\hline & $p=---$ & & & & & \\
\hline \multirow[t]{2}{*}{ Tempo } & -.0000 & 1 & & & & \\
\hline & $p=1.00$ & $p=---$ & & & & \\
\hline \multirow[t]{2}{*}{ Queratinócitos } & .0390 & *.7087 & 1 & & & \\
\hline & $p=.878$ & ${ }^{*} p=.001$ & $p=---$ & & & \\
\hline \multirow[t]{2}{*}{ Fibroblastos } & .0205 & *.9163 & *.6827 & 1 & & \\
\hline & $p=.936$ & ${ }^{*} p=.000$ & ${ }^{*} p=.002$ & $p=---$ & & \\
\hline \multirow[t]{2}{*}{$\begin{array}{c}\text { Células de } \\
\text { Defesa }\end{array}$} & .1957 & .3202 & .1260 & .1756 & 1 & \\
\hline & $p=.437$ & $\mathrm{p}=.195$ & $\mathrm{p}=.618$ & $\mathrm{p}=.486$ & $p=---$ & \\
\hline \multirow{2}{*}{$\begin{array}{c}\text { Vasos } \\
\text { Sanguíneos }\end{array}$} & -.1186 & *.8656 & *.4989 & *.8300 & .4673 & 1 \\
\hline & $p=.639$ & ${ }^{*} p=.000$ & ${ }^{*} p=.035$ & ${ }^{*} p=.000$ & $\mathrm{p}=.051$ & $p=---$ \\
\hline
\end{tabular}

*Valores com $\left({ }^{*}\right)$ mostram aonde $r$ foi significativo $(p<0.05)$ e alto. 
Apêndice C - Distribuição dos valores médios dos grupos de doses por tempo de eutanásia e quantidade celular de cada animal

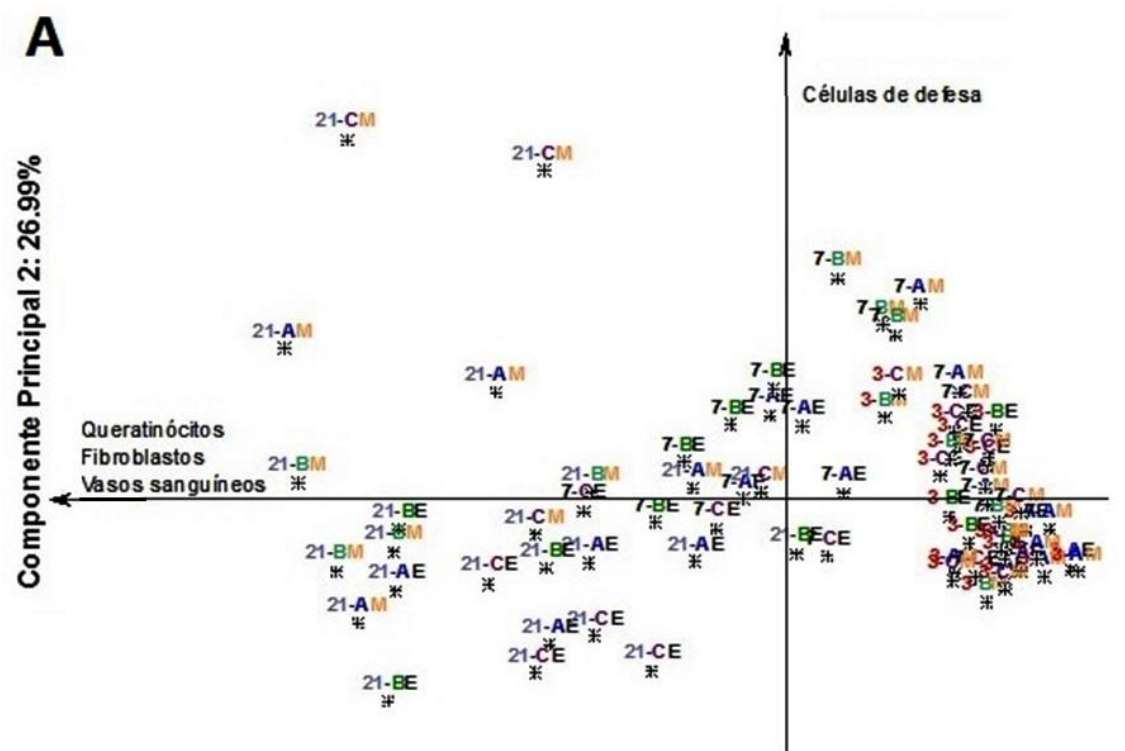

Componente Principal 1: $52.27 \%$

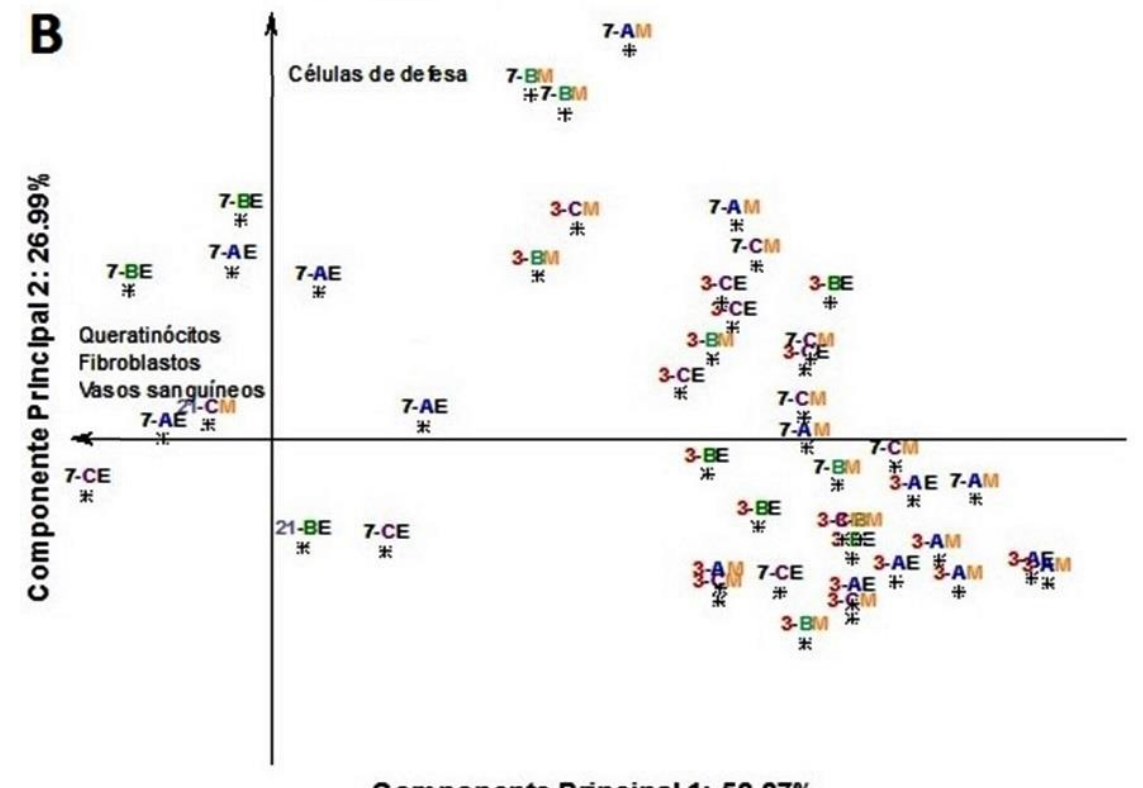

Componente Principal 1: $\mathbf{5 2 . 2 7 \%}$

Distribuição dos valores médios das células e vasos sanguíneos de cada animal. Os dias representados por $3^{\circ}, 7^{\circ}$ e $21^{\circ}$, os grupos de doses, sendo $A$ (não irradiado), B (irradiado $25 \mathrm{kGy}$ ) e C (irradiado $50 \mathrm{kGy}$ ) e local das contagens de células, $M$ (centro do tecido), $E$ (extremidades do tecido). Sendo $B$, uma ampliação do lado direito da A. 
Apêndice D - Controle das amostras das imunofluorescência dos tecidos de pele de camundongo NUDE e pele humana não irradiada e irradiada 25 kGy e 50 kGy, e marcação dos colágenos I humano, colágeno III e I de camundongo

- Controle dos tecidos das Imunofluorescências
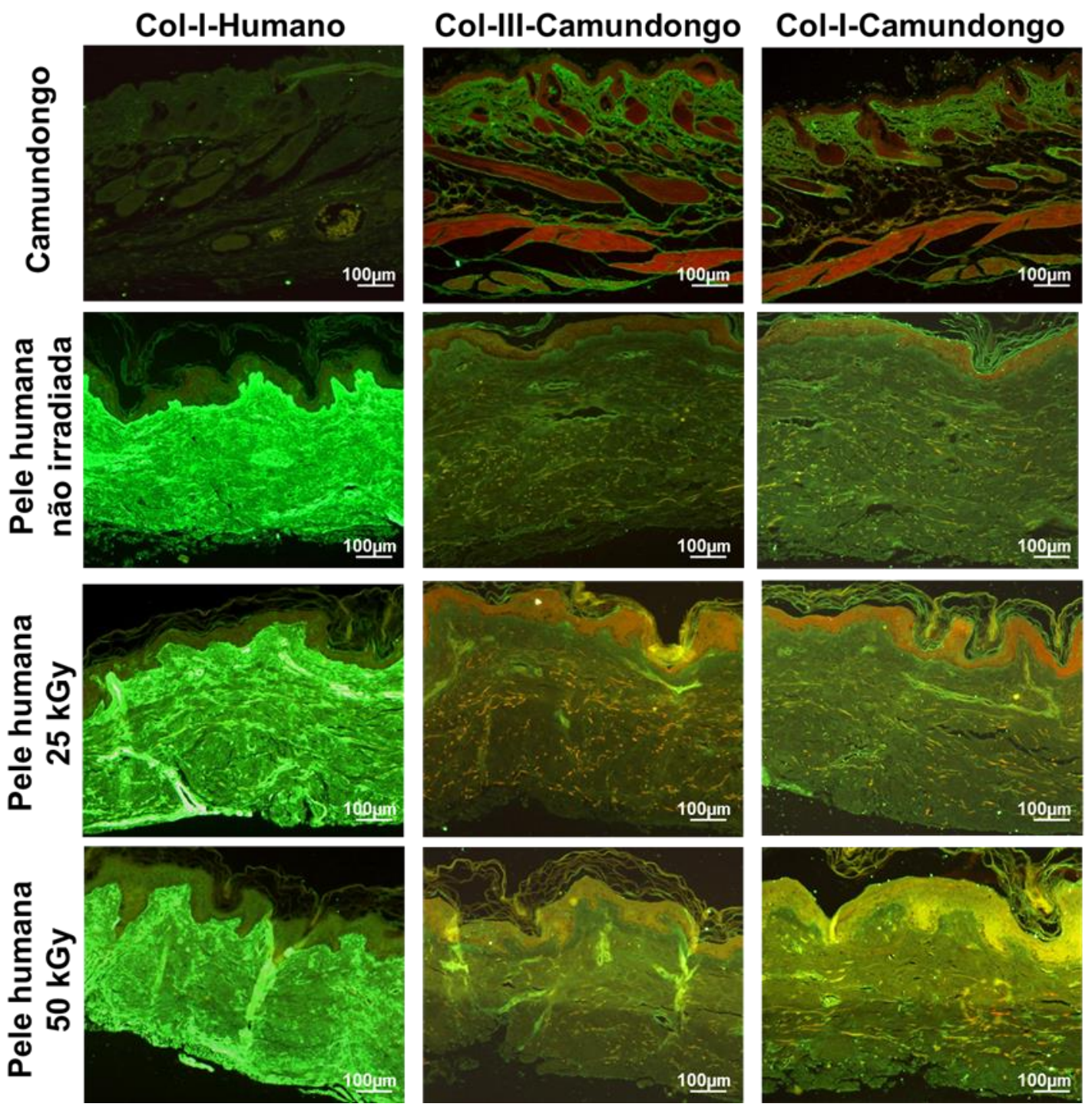

Imunofluorescência das amostras controle, com marcação em verde fluorescente, para o colágeno dos tipos I humano e dos tipos III e I de camundongo, em cortes transversais da pele humana e de camundongos Nude,. As imagens estão em aumento de $100 \mathrm{X}$ 
Apêndice $E$ - Distribuição da imunofluorescência dos tecidos do grupo não irradiado do $21^{\circ}$ dia após enxertia, com a IF de colágeno I humano, colágeno I e III de camundongo

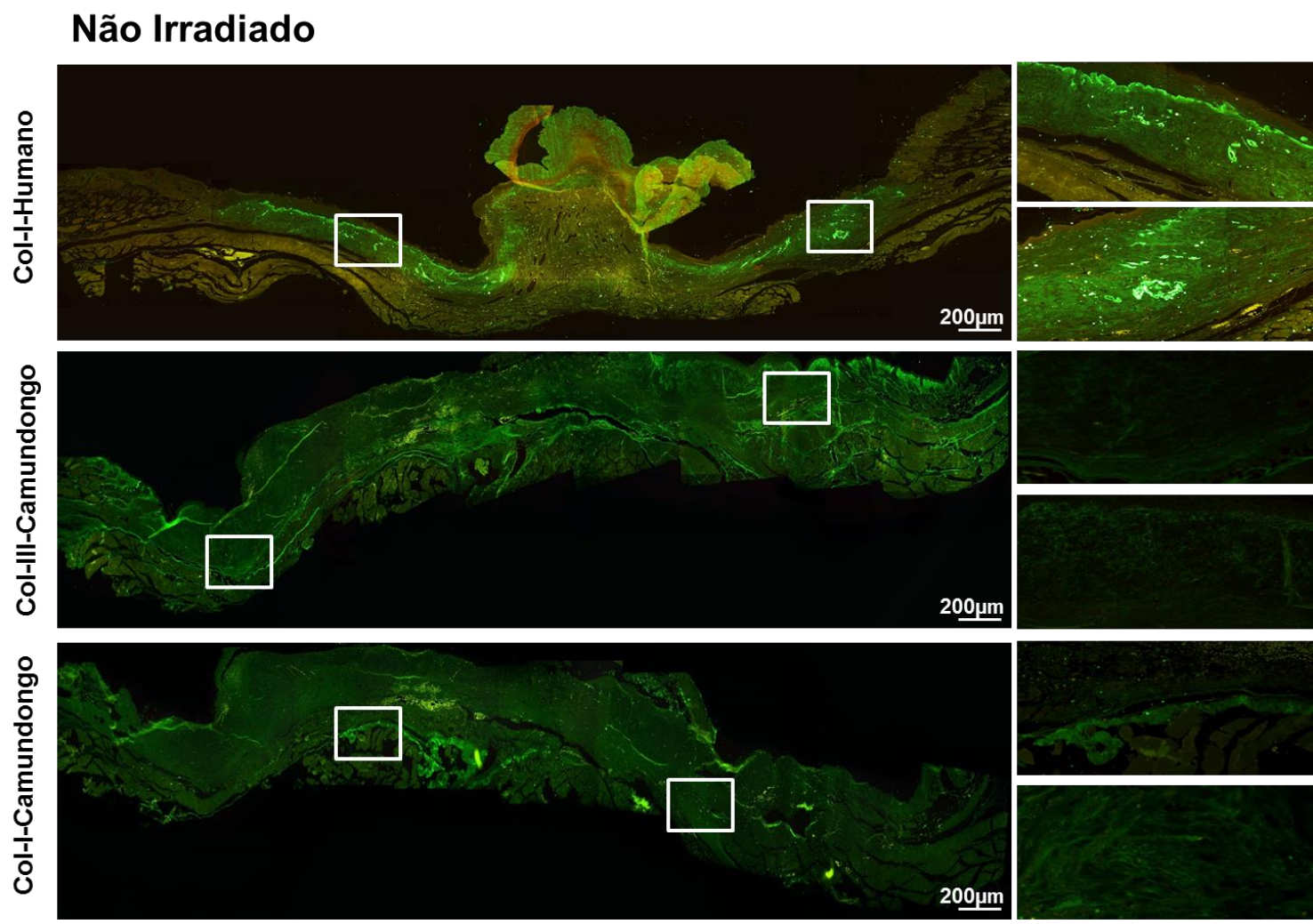

Imunofluorescência dos tecidos de pele humana enxertada em camundongos Nude, mostrando a marcação em verde fluorescente de colágeno I humano e colágeno III e I de camundongo. No grupo não irradiado, no $21^{\circ}$ dias após enxertia. As imagens estão em aumento de 100X. Os quadros nas laterais das imagens tem aumento de 200X. 
Apêndice F - Distribuição da imunofluorescência dos tecidos do grupo de 25 kGy do $21^{\circ}$ dia após enxertia, com a IF de colágeno I humano, colágeno I e III de camundongo

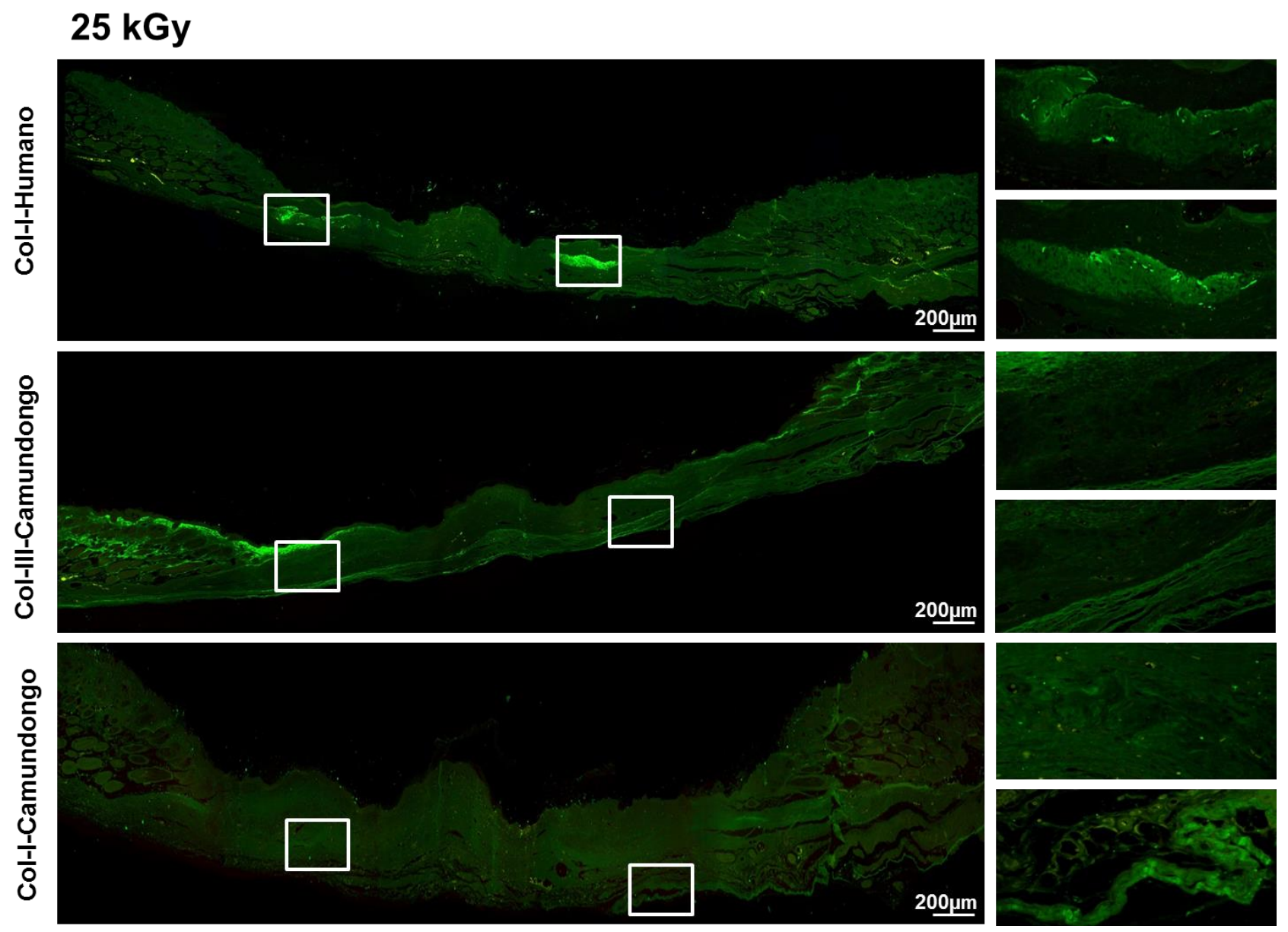

Imunofluorescência dos tecidos de pele humana enxertada em camundongos Nude, mostrando a marcação em verde fluorescente de colágeno I humano e colágeno III e I de camundongo. No grupo irradiado a 25 kGy, no $21^{\circ}$ dias após enxertia. As imagens estão em aumento de 100X. Os quadros nas laterais das imagens tem aumento de 200X. 
Apêndice $\mathrm{G}$ - Distribuição da imunofluorescência dos tecidos do grupo de 50 kGy do $21^{\circ}$ dia após enxertia, com a IF de colágeno I humano, colágeno I e III de camundongo

\section{0 kGy}
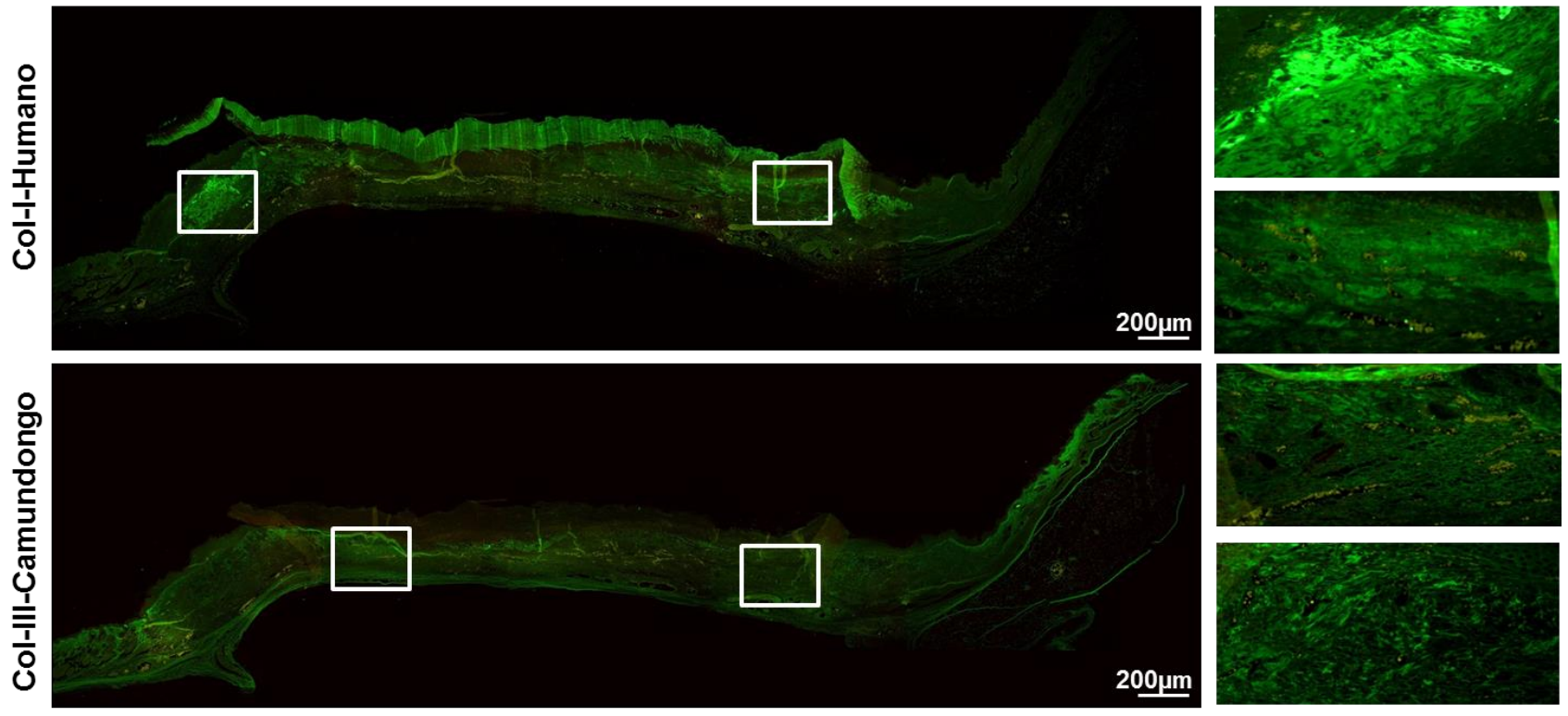

um
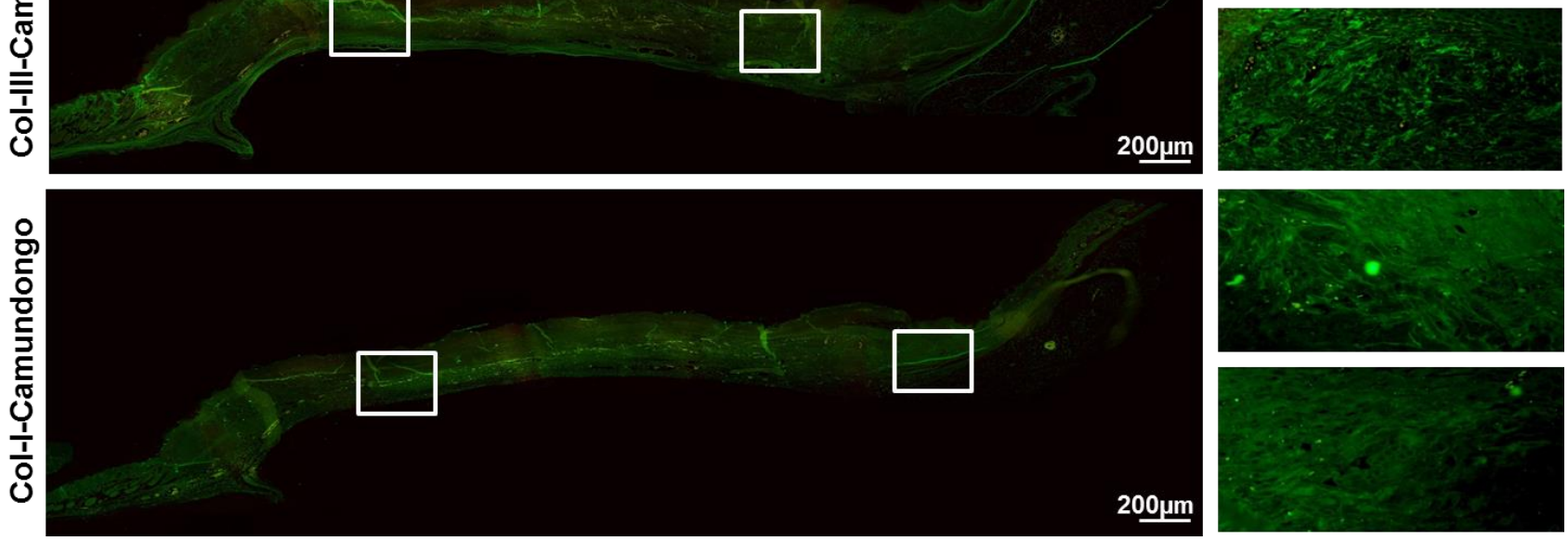

Imunofluorescência dos tecidos de pele humana enxertada em camundongos Nude, mostrando a marcação em verde fluorescente de colágeno I humano e colágeno III e I de camundongo. No grupo irradiado a $50 \mathrm{kGy}$, no 21ํㅡㄹ dias após enxertia. As imagens estão em aumento de 100X. Os quadros nas laterais das imagens tem aumento de 200X. 


\section{TRABALHOS FUTUROS}

Em função das conclusões obtidas com este trabalho, surgem questões tais como: a marcação de miofibroblastos por alfa actina, que mostraria o estágio da cicatrização e a marcação de colagenase, por degradar colágeno, assim poderia confirmar que o colágeno do enxerto esta sendo degradado, estando também ligado ao estagio em que a cicatrização se encontra, podendo confirmar se este enxerto ainda está sendo degradado ou se o colágeno remanescente foi definitivamente incorporado. 


\section{REFERÊNCIAS BIBLIOGRÁFICAS}

AARABI, S.; BHATT, K.A.; SHI, Y.; PATERNO, J.; CHANG, E.I.; LOH, S.A.; HOLMES, J.W.; LONGAKER, M.T.; YEE, H.; GURTNER, G.C. Mechanical load initiates hypertrophic scar formation through decreased cellular apoptosis. Faseb J; v. 21 p. 3250-61, 2007.

ANDRADE, A.;PINTO, S. C.; OLIVEIRA, R. S. orgs. Animais de laboratório: criação e experimentação. In: SANTOS. F. B...[online]. Rio de Janeiro: Editora FioCruz., Capitulo 18. Pag. 139-142, 2002. ISBN: 85-7541-015-6. Available from SciELO Books <http://books.scielo.org>.

BALBINO, C.A.; PEREIRA, L.M.; CURI, R. Mecanismos envolvidos na cicatrização: uma revisão. Revista. Brasileira. Ciências. Farmacêuticas, v.41, n. 1, p. 27-51, 2005.

BANCHEREAU, J. \& STEINMAN, R. N. Dentritic cells and the controlo $f$ immunity. Nature. N. 392, p. 245-252, 1998.

BLOCK, S. S. Disinfection, Sterilization, and Preservation. Lea \& Febiger, Philadélfia, Londres, 4 ed, 1991.

BLOTNIK, S.; PEOPLES, G. E.; FREEMAN, M. R. E.; EBERLEIN, T. J.; KLAGSBRUN, M. T. lymphocytes synthesize and export heparing-binding epidermal growth factor-like growth factor and basic fibroblast growth factor, mitogens for vascular cells and fibroblast differential production and release by CD4+ and CD8+ T cells. Proc. Natl. Acad. SCI. USA., v. 91, p. 2890-2894, 1994.

BOLGIANI, A. \& BENAIN, F. Actualización en el tratamiento de las quemaduras. Primer Banco de Piel de Argentina, organización y funcionamiento, cap. 12, p. 90-99. 1993. 
BOLGIANI, N. A. \& SERRA, M. C. V. F. Atualização no tratamento local das queimaduras. Rev Bras Queimaduras; 9 (2): p.38-44. 2010.

BOURROUL, S.C.; Caracterização dos efeitos da radiacao ionizante em pele humana para aloenxertos. Dissertação (Mestrado) - Instituto de Pesquisas Energéticas e Nucleares, São Paulo. 2004.

BRINGEL, F.A. Avaliação morfofuncional de pele humana conservada em glicerol e submetida à radiação gama: estudo em camundongos atímicos. 2011. 122f. Tese (Doutorado em Ciências na Área de Tecnologia Nuclear Aplicações) - Instituto de Pesquisas Energéticas e Nucleares, Autarquia Associada à universidade de São Paulo, São Paulo, 2011.

BURD, A.; LAM, P.K.; LAU, H. Allogenic skin: transplant or dressing? Burns. v. 28, Issue. 4. p. 358-366, 2002.

CHARLES RIVER LABORATORIES INTERNATIONAL. The Crl: NIH-Foxn1rnu Rat: A T-cell-deficient, athymic nude model. Research models and services 2009.

Disponivel: http://www.criver.com/files/pdfs/rms/rnu/rm rm d nude rat1.aspx Acesso em: Janeiro 2016.

COLWELL, A.S.; LONGAKER, M.T.; LORENZ, H.P. Fetal wound healing. Front. Biosci., v. 8, p. 1240-1248, 2003.

DAHLAN, K.Z.H.M. Radiation Sciences. In: PHIILLPS, G.O., NATHER, A. Advances in tissue banking - The Scientific Basis of Tissue Transplantation, World Scientific v. 5, , 2001.

DANG, C.; TING, K.; SOO, C.; LONGAKER, M.T.; LORENZ, H.P. Fetal wound healing current prerspectives. Clin. Plast. Surg., v. 30, p. 13-23, 2003.

DAVIS, D.A.; ARPEY C.J.; Porcine heterografts in dermatologic surgery and reconstruction. Dermatol Surg., 26:76-80, 2000. 
DÉMARCHEZ, M.; HARTMANN, D.J.; HERBAGE, D.; VILLE, G.; PRUNIÉRAS, M. Wound healing of human skin transplanted onto the Nude mouse: II. An immunohistological and ultrastructural study of the epidermal basement membrane zone reconstruction and connective tissue reorganization. Dev Biol; v. 121 p. 119-29, 1987.

DZIEDZIC-GOCLAWSKA, A. Aplicacion de la radiacion ionizante para esterilizar aloinjertos de tejido conectivo. In: PHILLIPS, G. O. (Ed). Radiacion y operacion de Banco de Tejidos. Perú: (confirmar) Printing service, 2001.

DZIEDZIC-GOCLAWSKA, A.; KAMINSKI, A.; UHRYNOWSKA-UHRYNOWSKATYSZKIEWICZ, I.; STACHOWICZ, W. Irradiation as a safety procedure in tissue banking. Cell and Tissue Banking, v. 6, p. 201-219, 2005.

ENGELHARD, E.; TOKSOY, A.; GOOBELER, M.; DEBUS, S.; BRÜCKER, E. B.; GILLITZER, R. Chemokines IL-8, Groa, MCP-1, IP-10, and Mig are sequentially and differentially expressed during phasespecific infiltration of leucocyte subsets in human wound healing. Am. J.Pathol., v.153, p. 1849-1860, 1998.

FOSTER, H.; SMALL, D.; FOX, G.;. The mouse in biomedical research. New York: Academic Press,. p. 272, 1983.

FRANCHINI, M.; ZANINI, D.; BOSINELLI, A. Evaluation of cryopreserved donor skin viability: the experience of the regional tissue bank of Verona. Blood Transfus, 7 (2) pp. 100-105, 2009.

GARTNER, L.P.; HIATT, J.L. Tratado de Histologia em cores. 3.ed. Rio de Janeiro: Elsevier. cap. 14p, tegumento. p. 253-266. 2007.

GAWRONSKA-KOZAK, B.; BOGACKI, M.; RIM, J.; MONROE, W.T.; MANUEL, J.A. Scarless skin repair in immunodeficient mice. Wound Rep. Reg. v. 14, p. 265-276, 2006. 
GOLCAMN, B.; GOLCMAN, R. Principais tipos e indicações de enxertos. In: GADELHA, A.R.; COSTA, I.M. (Ed). Cirurgia dermatológica em consultório. São Paulo: Atheneu; P. 285-91. 2002.

GRANATO, D, CALADO, V.M.A., \& JARVIS, B. Observations on the use of statistical methods in food science and technology. Food Res. Int., 55:137-149. 2014.

HARRIS, M. I. N. C. Pele: estrutura, propriedade e envelhecimento. 3.ed. São Paulo: Senac, 2009.

HERSON, M.R. \& MATHOR, M.B. Bancos de Tecidos In: GARCIA, V.D.; ABUD, M.; NEUMANN, J.; PESTANA, J.O.M. Transplantes de Órgãos e Tecidos, $2^{\underline{a}}$ Ed., São Paulo: Segmento Farma Editores Ltda. Cap. 16, p.174-185. 2006.

JUNQUEIRA, L.C.\& CARNEIRO, J. Histologia Básica. 12 ed. Rio de Janeiro: Guanabara Koogan, 2013.

KAPLAN, I. Física Nuclear, $2^{\circ}$ ed, Guanabara Dois, Rio de Janeiro, 1983

KERR, J.B. Atlas de Histología Funcional. São Paulo: Artes Médicas, cap. 8, p. 145-161. 2000.

KIERSZENBAUM, A.L. \& TRES, L.L. Histologia e Biologia Celular; Uma Introdução à Patologia. 3.ed. São Paulo: elsevier, 2012

KNIGHTON, D. R.; SILVER, I.; HUNT, T. K. Regulation of wound-healing angiogenesis-effect of oxygen gradients and inspired oxygen concentration. Surgery. v.90, p. 262-270, 1981.

KREIS, R.W.; HOEKSTRA, M.J.; MACKIE, D.P.; VLOEMANS, A.F.; HERMANS, R.P. Historical appraisal of the use of skin allografts in the treatment of extensive full skin thickness burns at the Red Cross Hospital Burns Centre, Beverwijk, The Netherlands. Burns.;18(Suppl 2): S19-22. 1992. 
LOFÊGO FILHO, J.A.; DADALTI, P.; SOUZA, D.C.; SOUZA, P.R.C.; SILVA, M.A.L.; TAKIYAIA, C.M. Enxertia de pele em oncologia cutânea. Anais. Brasileiros de Dermatologia. v. 81, n. 5, p. 465-472, 2006.

MACKIE, D.P. The Use of allogeneic skin in bums, hi: PHLLIPS, G.O. (Ed.). Advances in Tissue Banking. Singapore: World Scientific/IAEA, v. 3, p. 149-165. 2001.

MASSENO, A.P.B.; PORTO, C.D.; NUNES, L.C.; SEQUEIRA, J.L.; ALVARENGA, M.A. Miofibroblastos: revisão da leitura. Vet. Zootec., v. 17, n. 2, p. 177-190, 2010.

MCGOW, E.L.; VAN RAVENSWAAY, T.; DUMLAO, C.R. Histologic changes in Nude mouse skin and human skin xenografts following exposure to sulfhydryl reagents: arsenicals. Toxicologic Pathology, v. 15, n. 2, p. 149, 1987.

MOMTAZI, M.; KWAN, P.; DING, J.; ANDERSON, C. C.; HONARDOUST, D.; GOEKJIAN, S.; TREDGET, E. E. A nude mouse model of hypertrophic scar shows morphologic and histologic characteristics of human hypertrophic scar. Wound Healing Society. ed 21, p. 77-87, 2012.

MORDIFFI, S.Z. \& NATHER, A. Principles of sterile technique. In: PHILLIPS, G. O., NATHER, A. Advances in tissue banking v. 5 - The Scientific Basis of Tissue Transplantation, World Scientific, 2001.

MORRIS, J.P. Oxford textbook of surgery. 2. Ed. Oxford University Press. cap. 6, wound healing. P. 137, 2001.

NGUYEN, H.; MORGAN, D.A.F.; FORWOOD, M.R. Validation of $11 \mathrm{kGy}$ as a Radiation Sterilization Dose for Frozen Bone Allografts. Cell and Tissue Banking. v.26, n. 2, p.303-308, 2011. 
OBENG, M.D.; MCCAULEY, R.L.; BARNETT, J.R.; HEGGERS, J.P.; SHERIDAN, K.; SCHUTZLER, S.S. Cadaveric allograft discards as a result of positive skin cultures. Burns., 27:267-71, 2001.

OTTANI, V.; RASPANTI, M.; RUGGERI, A. Collagen structure and functional implications. Micron, v. 32, p. 251-260, 2001.

RABE, J.H.; MAMELAK, A.J.; MCELGUNN, P.J.S.; MORISON, W.L.; SAUDER, D.N. Photoaging: mechanisms and repair. J. Am. Acad. Dermatol., v. 55, n. 1, p. 1-19, 2006.

REED, N.; MANNING, D. Long-term maintenance of normal human skin on congenitally athymic (Nude) mice. Proc Soc Exp Biol Med; v. 3 p. 143:350, 1973.

ROSS, M.H.; PAWLINA, W. Histologia: texto e atlas. Em correlação com biologia celular e molecular. 6ed. Rio de Janeiro. Guanabara Koogan, 2012.

ROSSIO-PASQUIER, P.; CASANOVA, D.; JOMARD, A.; DÉMARCHEZ, M.; Wound healing of human skin transplanted onto de Nude mouse after a supercicial excisional injury: human dermal reconstruction is achieved in several steps by two different fibroblast subpopulations. Arch. Dermatol. Res., v. 291, p. 591-599, 1999.

SAMPAIO, S.A.P.; RIVITTI, E.A. Dermatologia. 3. ed. São Paulo: Artes Médicas. Cap. 1, pele normal: anatomia e fisiologia. P. 1-37. 2007.

SHANMUGAM, V.K.; TASSI, E.; SCHMIDT, M.O.; MCNISH, S.;BAKER, S.;ATTINGER, C.; WANG, H.;SHARA, S.; WELLSTEIN, A. Utility of a humanmouse xenograft model and in vivo near-infrared fluorescent imaging for studying wound healing. International Wound Journal. v. 12. Issue. 6. p. 699-705, 2015.

SHURCH, W.; SEEMAYER, T.A.; GABBIANI, G. Miofibroblast, In: MILLS, S. E. (Ed). Histology for pathologists. 3. Ed. Philadelphia: Lippincott-Wilkins Publishers. P. 129-160. 2006. 
SINGH, R.; SINGH, D.; SINGH, A. Radiation sterilization of tissue allografts: A review. World J Radiol. 8 (4): 355-369. 2016.

STRANDRING, S. Gray's Anatomy: The Anatomical Basis of Clinical Practice. 40. ed. New York, N.Y.: Churchill Livingstone, 2008.

TUGCU, H.; ZOR, F.; TOYGAR, M.; BALANDIZ,. H. Comparison of antemortem clinical diagnosis and postmortem findings in burn-related deaths. Ulus Travma Acil Cerrahi Derg.. v. 21(6) p. 491-495, 2015. doi: 10.5505/tjtes.2015.36604. Disponivel:http://www.ncbi.nlm.nih.gov/pubmed/27054641

VILLAPALOS, L.J.; M. ELDARDIRI, P.; DZIEWULSKI, A. The use of human deceased donor skin allograft in burn care. Cell Tissue Bank, 11 (1) , pp. 99-104, 2010.

WANG, J.; DING, J.; JIAO, H.; HONARDOUST, D.; MOMTAZI, M.; SHANKOWSKY, H. A.; TREDGET, E. E. Human hypertrophic scar-like nude mouse model: Characterization of the molecular and cellular biology of the scar process. Wound Rep Reg, v 19. p 274-285, 2010.

WURZER, P.; KEIL, H.; BRANSKI, L. K.; PARVIZI, D.; CLAYTON, R. P.; FINNERTY C. C.; HERDON, D. N.; KAMOLZ. L. P. The use of skin substitutes and burn care a survey. Journal of Surgical Research. Vol, 201, Issue 2, p. 293298, 2016.

ZIELINSKI, A.A.F., HAMINIUK, C.W.I., NUNES, C.A., SCHNITZLER, E., VAN RUTH, S. M., \& GRANATO, D.. Chemical composition, sensory properties, provenance, and bioactivity of fruit juices as assessed by chemometrics: a critical review and guideline. Compr. Rev. Food Sci. F., 13. 300-316, 2014. 


\section{ANEXOS}

Anexo A - Aspecto macroscopico das feridas e areas de reparação dos animais dos grupos experimentais com $3^{\circ}, 7^{\circ}, 21^{\circ}$ e $90^{\circ}$ dias após o enxerto de pele humana

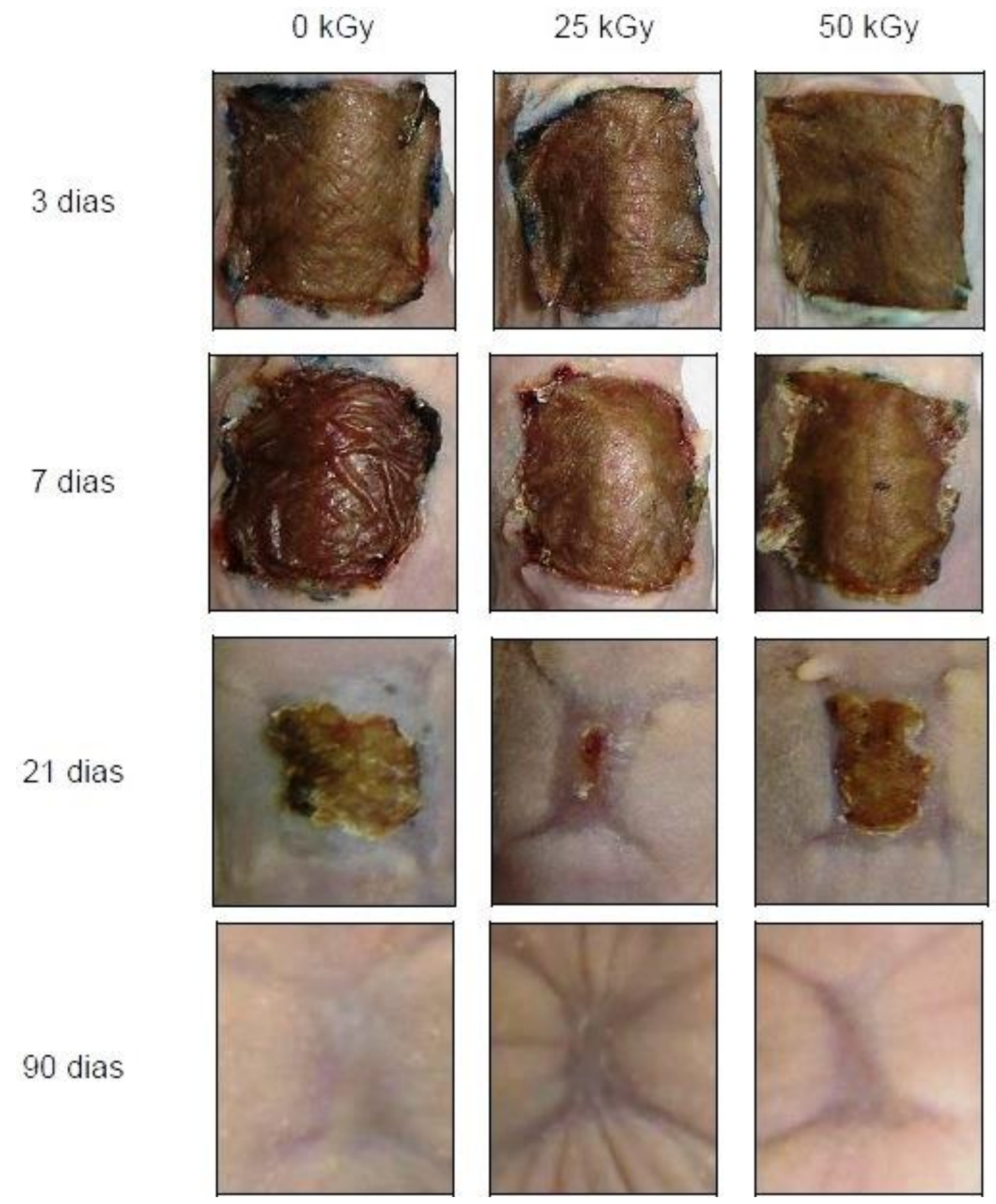

